ARCHIWA - KanCELARIE - ZBIORY

NR 1 (3)/2010

Krystian Chyrkowski

\title{
LISTY Z ZIEMI WAŁECKIEJ I KRAJNY DO KOŃCA XVIII WIEKU Z ZASOBU Archiwum Państwowego w Toruniu*
}

A trykuł jest próbą ukazania korespondencyjnych kontaktów osób i insty-
przedrozbiorowej Rzeczypospolitej ${ }^{1}$. W gruncie rzeczy jest to przedstawienie
kontaktów jednostronnych, ograniczone do listów napływających do Toru-
nia (obecnie znajdujących się w Archiwum Państwowym w Toruniu). Jednak
nie ulega wątpliwości, że istniał też kontakt „w drugą stronę”, czego dowodzi

Krystian Chyrkowski - Instytut Historii i Archiwistyki Uniwersytetu Mikołaja Kopernikaw Toruniu, e-mail: kch7@umk.pl. Zainteresowania badawcze: historia drugiej wojny światowej i najnowsza, lotnictwo i kolejnictwo.

* Tekst powstał na podstawie pracy magisterskiej napisanej pod kierunkiem prof. dr. hab. Janusza Tandeckiego.

${ }^{1}$ O ile oznaczenie granic Krajny nie napotyka większych trudności, o tyle wyznaczenie przebiegu południowej granicy ziemi wałeckiej jest już bardziej skomplikowane. Różne warianty prezentują np. E. Callier, Powiat watecki w XVI stuleciu. Szkic geograficzno-historyczny, Poznań 1886, s. 4; Z. Boras, R. Walczak, A. Wędzki, Historia powiatu wateckiego w zarysie, Poznań 1961 (dalej: HPWwZ), s. 91, 133-135; Historia kościota parafialnego $w$ Watczu spisana na podstawie prawdziwych dokumentów i wiarygodnych autorów przez Jana Ignacego Bocheńskiego proboszcza wateckiego w roku 1790, oprac. L. Bąk, M. Hlebionek, A. Szweda, Wałcz 2002 (dołączona do książki mapa). Dlatego też podczas kwerendy przyjęto, że południową granicę ziemi wałeckiej stanowią obecne południowe granice powiatów wałeckiego i pilskiego (bez gminy Ujście). 
treść niektórych ze zregestowanych listów. Prezentowane w artykule materiały to raczej zbiór „streszczen" źródeł, jakimi są przeanalizowane listy. Nie służą one przeprowadzaniu jakichkolwiek analiz, wysuwaniu hipotez. Mają jedynie na celu obiektywne przedstawienie bardzo wąskiego wycinka historii z przeszłości ziemi wałeckiej, Krajny i Torunia, także w ujęciu archiwistycznym i nauk pokrewnych.

W tym miejscu chciałbym serdecznie podziękować dr. Marcinowi Hlebionkowi za jego cenne spostrzeżenia, którymi zechciał podzielić się ze mną i które były mi pomocne w trakcie pisania tego artykułu.

W początkach XIV wieku ziemia nakielska (Krajna) leżała już w granicach państwa Łokietka. Ziemia wałecka natomiast została przyłączona do Polski dopiero przez Kazimierza Wielkiego w 1368 roku. Po jego śmierci ziemia wałecka (oraz leżąca na pograniczu Krajny ziemia złotowska) stała się areną walk między książętami polskimi i pomorskimi. Dopiero w 1391 roku Władysław Jagiełło wykupił ją i przyłączył do Korony. Od tego roku powiat wałecki przynależał do województwa poznańskiego, natomiast powiat nakielski znajdował się w granicach województwa kaliskiego (a od $1768 \mathrm{r}$. w nowym województwie gnieźnieńskim). Wiek XV to okres krzyżackich najazdów i powodowanych nimi spustoszeń, m.in. w latach 1409, 1414, 1422, $1431 \mathrm{i}$ w okresie wojny trzynastoletniej 1454-1466. Ziemie te odczuły też skutki potopu szwedzkiego i wojny północnej, zanim w 1772 roku zostały włączone w wyniku rozbiorów do Prus. Wcześniej, bo już w 1668 roku, odpadł od państwa polskiego Drahim z Czaplinkiem i Mirosławcem.

Maria Bogucka i Henryk Samsonowicz w swojej pracy poświęconej polskim miastom i mieszczanom wyróżnili cztery grupy miast: I - duże, II - średnie, III - małe, IV - najmniejsze. W zestawieniu obejmującym XV wiek miasta Krajny i ziemi wałeckiej zaklasyfikowano do dwóch ostatnich grup: małych i najmniejszych. Do małych zaliczono: Czaplinek, Człopę, Nakło, Wałcz, a do najmniejszych: Drahim, Kamień, Krajenkę, Miasteczko, Mirosławiec, Mroczę, Piłę, Sępólno i Więcbork² ${ }^{2}$.

Przyjęło się dzielić ludność średniowiecznych miast na trzy grupy: patrycjat, pospólstwo i plebs. Taki podział był wyraźny w wielkich, „podręcznikowych” miastach. W miasteczkach Krajny i ziemi wałeckiej trudniej byłoby wyodrębnić powyższe grupy. Patrycjat w tamtych warunkach właściwie nie istniał. Natomiast ze zregestowanych w tym katalogu listów wynika, że do władz miejskich wchodzili przede wszystkim rzemieślnicy i kupcy (czyli

2 M. Bogucka, H. Samsonowicz, Dzieje miast i mieszczaństwa w Polsce przedrozbiorowej, Wrocław-Warszawa-Kraków-Gdańsk-Łódź 1986, s. 115. 
przedstawiciele wielkomiejskiego pospólstwa). Ujednoliceniu społeczeństwa tych miast sprzyjał też ich często rolniczy charakter (np. Kamień, Sępólno i Więcbork). Jednak jak na miasta przystało, swoją działalność prowadzili w nich przedstawiciele różnych rzemiosł: piekarze, piwowarzy, sukiennicy, płóciennicy, krawcy, szewcy, garbarze, kuśnierze, cieśle, bednarze, kowale, garncarze, murarze i wielu innych. W celu obrony swych interesów i pilnowania jakości świadczonych usług zrzeszali się w cechy. W przypadku przeprowadzki któregoś z członków danego cechu jego władze poświadczały pisemnie status takiej osoby, polecając ją niejako cechowi w innym mieście.

W handlu dominowali Niemcy, od XVIII wieku również Żydzi, a nawet Szkoci. Ludność żydowska mieszkała praktycznie we wszystkich miastach na terenie obu powiatów. Jedynie w dobrach arcybiskupów gnieźnieńskich w Kamieniu Żydzi mieli bezwzględny zakaz osiedlania się̧3. Natomiast Szkoci swoim osadnictwem przyczynili się do powstania Nowego Miasta Łobżenicy (zwanego „Małym Gdańskiem”). Łobżenica była doskonałym ośrodkiem z kupieckiego punktu widzenia - było to krajeńskie centrum przemysłu tkackiego, mogące poszczycić się kontaktami handlowymi z Gdańskiem (podobne znaczenie w powiecie wałeckim miało Jastrowie $)^{4}$.

Większość mieszkańców miast powiatu wałeckiego stanowiła ludność pochodzenia niemieckiego, przybyła i wciąż napływająca jako koloniści. W czasie gdy reformacja szerzyła się w Europie, ta część społeczeństwa wraz z częścią szlachty była niejako zapleczem dla myśli reformacyjnej na omawianym obszarze 5 . Począwszy od XVI wieku, luteranie poczęli zyskiwać tu coraz większe wpływy. Największymi ośrodkami reformacji w regionie stały się: Czaplinek, Mirosławiec, Tuczno, Człopa, Wałcz, Jastrowie, Łobżenica i Nakło.

Powiaty nakielski i wałecki szczyt rozwoju społecznego i gospodarczego przeżywały w drugiej połowie XVI wieku. Jednak wojny, które wkrótce zaczęły ogarniać Europę, nie oszczędziły i tego regionu. Rozpoczął się wówczas jego powolny upadek. Pewne pobudzenie jego rozwoju przyniósł napływ kolonistów na przełomie XVII i XVIII wieku ${ }^{6}$.

W dniu 5 sierpnia 1772 roku w Petersburgu zapadły ostateczne decyzje o rozbiorze Polski. Tak zwany obwód nadnotecki z Krajną i ziemią wałecką

3 B. Janiszewska-Mincer, Od początków miasta do czasów rozbiorów, [w:] Nakto nad Notecia. Dzieje miasta i okolic, red. J. Danielewicz, Nakło nad Notecią 1990, s. 148.

4 Tamże; HPWwZ, s. 171.

5 L. Bąk, Ziemia watecka $w$ dobie reformacji i kontrreformacji $w$ XVI-XVIII $w$., Piła 1999, całość.

6 P. Szafran, Osadnictwo historyczne Krajny w XVI-XVIII wieku (1511-1772), Gdańsk 1961, s. 50, 106-107. 
przypadł Prusom7. Już 13 września 1772 roku wojska pruskie zaczęły zajmować tereny powiatów wałeckiego i nakielskiego. Podążający za nimi urzędnicy w każdym mieście ogłaszali przyłączenie tych ziem do Prus i wprowadzenie pruskiej administracji ${ }^{8}$. Z zajętego obszaru utworzono prowincję Prusy Zachodnie - Westpreußen - ze stolicą w Kwidzynie. Wyraźnie zaznaczano pewną odrębność obwodu nadnoteckiego - Netzdistrikt, który ostatecznie w 1775 roku stał się departamentem. Prowincja ta została podzielona na powiaty - Kreis; w obwodzie nadnoteckim ostatecznie wykształciły się cztery powiaty: wałecki, kamieński, bydgoski i inowrocławski .

W latach 1793 (wówczas do Prus włączono również Toruń) i 1795 doszło do drugiego i trzeciego rozbioru Polski. Prusy zyskały kolejne ziemie na południe od Noteci. Zarówno Krajna, jak i ziemia wałecka przez cały XIX wiek znajdowały się w granicach Prus, a potem państwa niemieckiego. Terytorium osiemnastowiecznego powiatu nakielskiego powróciło do Polski w 1919 roku, a powiatu wałeckiego dopiero w 1945 roku.

W niniejszym artykule przedstawiono 75 listów pochodzących z obszaru ziemi wałeckiej i Krajny, a obecnie przechowywanych w Archiwum Państwowym w Toruniu. Nie wyczerpują one jednak całości korespondencji ze wspomnianego regionu, która jest przechowywana w archiwum. Kwerendzie zostały poddane jedynie tzw. Katalog II (Akta miasta Torunia) i Katalog III (Listy cechowe). Nie można zaręczyć, że w pozostałych zespołach cechów, związków wyznaniowych i innych z okresu do końca XVIII wieku nie ma pojedynczych egzemplarzy takich listów. Przeszukanie Katalogu III nie stanowiło większego problemu - zachował się do niego inwentarz sporządzony w XIX wieku. Gorzej sprawa wyglądała z Katalogiem II. W tym zespole jednostkami archiwalnymi są w dużej części poszyty, nierzadko ośmiuset-, dziewięćsetstronicowe. Zgromadzono w nich m.in. pisma wpływające i powstające w urzędach Torunia. W tym wypadku niewiele mogły pomóc sporządzone dla zespołu karty inwentarzowe. Pozostawało tylko wertowanie poszytów. Z tego zespołu pochodzą jedynie listy osiemnastowieczne, starszych nie znaleziono. Należy zaznaczyć, że przeszukano poszyty z serii (wyodrębnionych przez archiwistów), w których hipotetycznie mogły znaleźć się listy z obszaru ziemi

7 Historia Polski, t. 2, cz. 1: 1764-1814, red. T. Manteuffel i in., Warszawa 1956, s. 98.

8 J. Księski, Nakto w okresie zaboru pruskiego (1772-1920), [w:] Nakto nad Notecia, s. $160 ; H P W w Z$, s. 199.

9 Odesłania do literatury np. w artykule: M. Hlebionek, Sumariusz średniowiecznych $i$ wczesnonowożytnych (do końca XVI w.) dokumentów z akt Deputacji Kamery Wojennej i Domen w Bydgoszczy, Ziemia Kujawska, t. 21, 2008, s. 59, przyp. 2. 
wałeckiej i Krajny. W ponad 130 przejrzanych poszytach z Katalogu II znaleziono łącznie 46 listów, pozostałe 29 znajdowało się w Katalogu III. Najstarszy list pochodzi z roku 1402 (list nr 49 z Mirosławca), a najmłodszy z 1799 (list nr 16 z Krajenki). Brakuje listów z XVI wieku, w „śladowych” ilościach występuje korespondencja piętnasto- i siedemnastowieczna. Listy pochodzą z dwunastu różnych miast, najwięcej z Łobżenicy - aż 32 .

Zgromadzoną korespondencję można podzielić ze względu na wystawcę na: sądową (sądy miejskie, wójtowskie - Vogtey i patrymonialne), miejską (rady miast), cechową (starsi cechów i rady miejskie), związaną ze sprawami wyznaniowymi (gmina ewangelicka) i prywatną. Kwestie poruszane w korespondencji sądowej i miejskiej właściwie nie różnią się od dzisiejszych. Pisma były sporządzane doraźnie i każdorazowo opatrywane podpisami jednego lub kilku przedstawicieli danego sądu lub rady miejskiej, rzadziej pieczęcią.

W grupie listów cechowych można wyróżnić: listy dobrego urodzenia $(G e-$ burtsbrief), listy zaświadczające o odbytej nauce rzemiosła (Lehrbrief) i listy polecające (Empfehlungsbrief). Przeważają listy dobrego urodzenia wystawiane przez rady miejskie na życzenie zainteresowanych, w których poświadcza się prawe pochodzenie posiadacza listu, zawsze oparte na zeznaniach dwóch wiarygodnych świadków. Rzadko jednak o wydanie takiego listu występowała osoba, której on dotyczył - najczęściej był to przyjaciel lub krewny. „Prawdziwe" listy cechowe - listy nauki rzemiosła - często były wystawiane przez radę miejską lub opatrzone jej pieczęcią. Potwierdzano w nich z reguły odbycie nauki przez daną osobę, wywiązanie się z wszelkich powinności wobec korporacji i prawo do przystępowania do cechów. W listach polecających władze miejskie polecały okaziciela listu. Jest też kilka zaświadczeń rad miejskich o nienagannej opinii, jaką cieszył się okaziciel jako mieszczanin danego miasta, były one wydawane na prośbę osoby przenoszącej się do innego miasta.

Listy związane ze sprawami wyznaniowymi to wyłącznie prośby o wsparcie finansowe łobżenickiej gminy ewangelickiej pochodzące z różnych lat. Listy osób prywatnych mają charakter zarówno próśb, jak i podziękowań. Jedynie te od zamożniejszych osób oprócz tego, że zawierają podpisy, są też opieczętowane. $\mathrm{Na}$ marginesie tych dwóch ostatnich grup należy wspomnieć o trzech listach (nr 23, 47 i 48), które napisano w Toruniu. Jednak ich autorzy byli mieszkańcami Łobżenicy i dlatego uznano, że powinny być one dołączone właśnie do listów z tego miasta.

Listy pisano na pergaminie lub papierze. Co ciekawsze, te pisane na pergaminie, pochodzą wyłącznie z XVIII wieku - są to głównie listy dobrego urodzenia z Katalogu III. Można więc wysunąć hipotezę, że to późniejszy okaziciel finansował materiały piśmiennicze i być może taki list na pergaminie miał świadczyć o jego zamożności. Prawie wszystkie listy napisano od- 
ręcznie, jedynie sześć z Czaplinka i Mirosławca sporządzono na drukowanych formularzach, gdzie odręcznie wypełniano tylko wyznaczone miejsca (listy nr 2, 3, 5, 55, 56, 57). Formaty listów są różne - od skrawków papieru po całkiem spore pergaminowe arkusze. Wiele listów przycięto nierówno, dlatego podane w opisach wymiary należy traktować orientacyjnie. W listach z Katalogu III przeważają pojedyncze, złożone karty. Z kolei listy z Katalogu II mają postać bifoliów zszytych w poszyty. Pewnej ich części brakuje drugiej karty, na której umieszczano adres. Karty te wyrwano bądź wycięto już po wszyciu. Najpewniej uczyniono to w celu „odchudzenia” poszytu, ale nie jest też wykluczona działalność „kolekcjonerów” zbierających odciski pieczęci. Sposób zszycia powodował zagięcie około $1-1,5 \mathrm{~cm}$ grzbietu bifolium, co podczas analizowania treści listu bywa uciążliwe.

W korespondencji z Toruniem powszechnie używano języka niemieckiego, co nie dziwi, jeśli weźmie się pod uwagę przygraniczne położenie miast, z których ją nadsyłano. W języku polskim napisano jedynie trzy (listy nr 25, 65, $74+61$ - adres w języku polskim, ale treść w języku niemieckim), a po łacinie pięć (listy nr 17, 28, 29, 62 i 75). W jednym przypadku list zaadresowano w języku francuskim (list nr 54). Pisma sądów, rad miast, cechów, a nawet osób prywatnych sporządzali „etatowi” pisarze: zaprzysiężeni pisarze miejscy, sądowi i prywatni. Po 1772 roku na pismach sądowych z Łobżenicy i Piły są już widoczne w prawym dolnym rogu podpisy pisarzy, którzy je sporządzili (Borzz [?], Pirschel). We wcześniejszych listach podpisy pisarzy pojawiały się rzadko, występowały raczej jako podpisy jednej z osób potwierdzających ich autentyczność.

Stan zachowania listów jest różny - ogólnie można określić go jako dobry. Oczywiście, niektóre najstarsze przekazy są przedarte w miejscu złożeń, w listach osiemnastowiecznych występuje wspomniany brak drugiej karty bifolium. Pojawiają się też uszkodzenia biologiczne i zwykłe zabrudzenia. Te ostatnie dotyczą zwłaszcza rewersów listów z Katalogu III - wynika to z wcześniejszego sposobu ich przechowywania, kiedy to były narażone na stałe zakurzenie.

Jak już wspomniano, nie na każdym liście stawiano pieczęć. W listach pergaminowych pieczęć woskową (umieszczoną w drewnianym lub metalowym kapslu) często mocowano do złożonej dolnej krawędzi karty (tzw. plica). Czyniono to za pomocą różnokolorowych tasiemek, ewentualnie pasków pergaminu. Na listach papierowych stosowano bardziej różnorodne sposoby odciskania pieczęci. Występują tu pieczęcie woskowe (listy piętnastowieczne), lakowe, papierowo-lakowe (w tym takie, gdzie lak umieszczano między kartami bifolium, uniemożliwiając ich rozłożenie), opłatkowe i drukowane. Można też wyróżnić pieczęcie ze względu na ich użytkownika. W zebranej 
korespondencji pojawiają się pieczęcie miejskie, sądowe, cechowe i prywatne (zwykle sygnetowe). Niekiedy, zamiast pod treścią pisma, pieczęć przystawiano na krawędziach złożonego w „kopertę” listu (podczas jego otwierania pieczęć była łamana lub odpowiednio nacinano kartę, nie uszkadzając jej). $\mathrm{Na}$ potrzeby opisu katalogowego dla tego rodzaju pieczęci, jak i drukowanych (skarbowych) przyjęto następujące nazewnictwo. I tak, pieczęcie zamykające złożony list są określane jako zabezpieczające. Okrągła (średnica ok. $30 \mathrm{~mm}$ ), drukowana pieczęć z pruskim orłem w koronie, z jabłkiem i berłem w szponach, z tekstem „VIER G[OLDEN]: GROSCHEN”, została określona jako stempel opłaty skarbowej. Kolejna pieczęć, również drukowana, okrągła, o średnicy ok. $30 \mathrm{~mm}$, z wpisanymi stylizowanymi literami F[ridericus] R[ex], jest określana jako stempel z inicjałami. Te dwie ostatnie pieczęcie występują zwykle w obu górnych rogach pism sądowych i drukowanych formularzy. W opisie katalogowym, wobec powszechnego ich użycia, zaznaczono tylko obecność w liście dwóch stempli drukowanych. Opisane są jedynie ewentualne różnice. Pieczęcie miejskie mają zwykle na wizerunkach herby miast, pieczęcie cechowe przedstawiają atrybuty danego rzemiosła, a prywatne herb właściciela. W przypadku pieczęci sądów można stwierdzić, że po 1772 roku Prusacy je ujednolicili. Na każdej znajdował się pruski orzeł w koronie z berłem i jabłkiem w szponach, a na obwodzie widniała nazwa sądu ${ }^{10}$.

Pominięte zostały opisy pieczęci omówionych w literaturze przedmiotu - przy czym oparto się na jednej z najnowszych pozycji, jaką jest Heraldyka miast wielkopolskich do końca XVIII wieku Marka Adamczewskiego (w opisach katalogowych skrót $H M W)^{11}$. W pracy jest też zawarta obszerna bibliografia tematu. Nieujęte w niej pieczęcie zostały opisane pod regestem danego listu. W niektórych przypadkach uszkodzenia pieczęci (pęknięcia, ubytki) utrudniały jej przeanalizowanie. Niekiedy pieczęcie w całości wykruszyły się bądź też zostały wyrwane z fragmentem karty. Od 2003 roku wszystkie listy z Katalogu III są opieczętowane tuszową pieczęcią Archiwum Państwowego w Toruniu (znajdującą się zawsze w pobliżu tekstu).

Korespondencja sporządzona na papierze jest opatrzona znakami wodnymi (większość listów z Katalogu II, znacznie mniej z Katalogu III). Znaki wodne (filigrany) były umieszczane na papierze jako „znak firmowy” papier-

10 Tematykę pieczęci sądów patrymonialnych, również występujących w skatalogowanej korespondencji, poruszył P. Gut, Pieczęcie sądów patrymonialnych $w$ Prusach w XVIII-XIX wieku na przyktadzie prowincji Pomorze, [w:] Wokót znaków i symboli. Herby, pieczęcie i monety na Pomorzu, Ślasku i Ziemi Lubuskiej do 1945 r., red. A. Chlebowska, A. Gut, Warszawa 2008, s. 67-77.

${ }^{11}$ M. Adamczewski, Heraldyka miast wielkopolskich do końca XVIII wieku, Warszawa 2000 (dalej: $H M W$ ). 
nika i jako oznaczenie gatunku papieru. Ich motywy były różne - przedstawiały herby właścicieli młyna papierniczego (bądź gruntu, na którym się znajdował), postacie świętych, insygnia władzy, zwierzęta, rośliny, litery, figury geometryczne i wiele innych. Teoretycznie każdy papiernik powinien był posiadać własny, niepowtarzalny znak wodny. W praktyce istniały filigrany stosowane w całej Europie w wielu wariantach - tzw. filigrany konwencjonalne. Rozpoznanie młyna, w którym powstał dany papier, może ułatwiać znak pomocniczy (nazwisko, inicjały, nazwa miejscowości i inne), umieszczany zwykle na drugiej połowie arkusza ${ }^{12}$. W badanej korespondencji występuje kilka rodzajów filigranów konwencjonalnych:

- „kwiat w wazonie” oraz „goździk” - w Niemczech znane jako die Nel$k e n-\mathrm{w}$ Polsce powszechny w produkcji papierni pomorskich (gdańskich) ${ }^{13}$;

- „ryba” - powszechny w produkcji papierni z terenów nad Zatoką Gdańską $^{14}$;

- „Madonna” (w ognistej aureoli, mandroli) - występował w całej Europie, w Polsce powszechny w papierniach pomorskich, mazowieckich i śląskich ${ }^{15}$;

- „Horn” (róg pocztowy) - występował w całej Europie, na zachodzie stosowany do oznaczania papieru listowego ${ }^{16}$;

- „Pro Patria” - występował w całej Europie, naśladownictwo wzorów holenderskich (Pro Patria to symbol walk niepodległościowych Niderlandów przeciw Francji i Hiszpanii) ${ }^{17}$;

- „Strassburg” (w Polsce podwójna lilia lub herb Gozdawa) - występował w całej Europie ${ }^{18}$.

Po 1772 roku częstym motywem stał się pruski orzeł w koronie, trzymający w szponach insygnia władzy: berło i jabłko, rzadziej miecz. Wielu

12 Więcej na temat filigranów: J. Dąbrowski, J. Siniarska-Czaplicka, Rękodzieto papiernicze, Warszawa 1991 (dalej: Rękodzieto).

13 J. Siniarska-Czaplicka, Katalog filigranów papierni polskich 1500-1800, Łódź 1983 (dalej: Kat. fil.), s. 31; Rękodzieto, s. 348, 353, tablica IX, fil. 80; G. Spoer, Rosen, Tulpen, Nelken... Aus der Formenwelt der Wasserzeichenkunst, Leipzig 1987, s. 22.

${ }^{14}$ Kat. fil., s. 32; Rękodzieto, s. 348.

15 Kat. fil., s. 32; Rękodzieto, s. 382 oraz 354, tablica IX, fil. 82.

${ }^{16}$ Kat. fil., s. 32; Rękodzieto, s. 382 oraz 390, tablica XI, fil. 98.

17 Kat. fil., s. 32; Rękodzieto, s. 382 oraz 392, tablica XI, fil. 104; F. Pabich, Papiernie nadnoteckie, Przegląd Papierniczy, t. 355, nr 8, 1973, s. 290.

${ }_{18}$ Rękodzieto, s. 256 oraz 329, tablica I, fil. 7; С. А. Клепиков, Филиграни и штемпели на бумаге русского и иностранного производства XVII-XX в.в., Москва 1959, s. 24. 
znaków wodnych nie udało się odnaleźć w najpopularniejszych katalogach i opracowaniach. Arkusze papieru oznaczone znakiem głównym i pomocniczym zwykle składano na pół, w bifolium - wtedy znaki występowały na obu kartach, stąd w opisie są wyszczególnione pierwsza i druga karta. Niekiedy sposób pieczętowania listu (umieszczenie laku między kartami) uniemożliwiał dokładniejsze zapoznanie się z filigranami. Rozpoznanie pochodzenia znaku wodnego utrudniał brak kart z adresem w niektórych poszytach.

Na potrzeby katalogu wyodrębniono cztery rodzaje dopisków występujących na listach. Pierwszym dopiskiem, w cudzysłowie, jest adres umieszczany na ostatniej stronie listu w taki sposób, by po jego złożeniu stanowił awers koperty. Adres był pisany, tak jak treść listu, czarnym atramentem. W opisie do przytaczanego dosłownie adresu dodawano też dopiski pochodzące od nadawcy/poczty, np. franco.

Drugi rodzaj to właściwe zapiski dorsalne, umieszczane w okolicach adresu. Składają się na nie notki kancelarii magistratu toruńskiego dotyczące nadawcy, miasta wysłania, rodzaju sprawy i daty otwarcia listu lub przedstawienia odpowiedniemu organowi władz miejskich (lect[um], illat[um]). Porównując dzień wystawienia listu z dniem jego lektury, można stwierdzić, że różnice sięgają od kilku dni do kilku lat (!). Jednak ten ostatni okres dotyczy szeroko pojętych listów cechowych, które raczej podróżowały z ich właścicielem, a nie były dostarczane przez pocztę. Napisy in dorso wykonywano za pomocą atramentu, najczęściej czarnego. Dorsalia wpisywane po wpłynięciu pisma do odbiorcy pojawiły się po roku 1720 , ale nie występują na wszystkich późniejszych listach. Do zapisków dorsalnych zaliczono też wszelkie dopisane cyfry, liczby, działania matematyczne i symbole - te były wykonywane czarnym i czerwonym atramentem. Czy miały one jakikolwiek związek z listem, czy po prostu list pełnił funkcję brudnopisu i czy zostały wykonane w magistracie toruńskim - tego nie można stwierdzić.

Noty kancelaryjne stanowią trzeci rodzaj dopisków. Występują na awersie listów i z pewnością zostały sporządzone w kancelarii wystawcy. Składają się na nie noty typu Copia, nazwa odbiorcy, numer kolejny pisma (występuje praktycznie tylko w pismach sądowych) oraz podpis pisarza. Ich rozmieszczenie na karcie w opisie katalogowym określono skrótami: $[\mathrm{g}]$ - góra na środku, [d] - dół na środku, [p] - z prawej, [l] - z lewej i ich kombinacjami. Do tych dopisków zaliczono też podsumowania kosztów sprawy.

Ostatnim, czwartym rodzajem dopisków są wszelkie adnotacje archiwistów niemieckich i polskich. Występują one, w zależności od zespołu, na awersie (Katalog II) lub rewersie listu (Katalog III). Dotyczą z reguły miejsca i daty wystawienia; w Katalogu II dochodzi do tego foliacja i nowsza paginacja oraz 
numer serii w zespole (3, 3a, 5, 7, 16); wykonywano je zwykłym ołówkiem ${ }^{19}$. Z kolei w Katalogu III, oprócz miejsca i daty wystawienia, podawano też osobę, której list dotyczył, jej zawód oraz sygnaturę archiwalną - zapisywano to zwykle niebieską kredką tak, by po złożeniu listu opis znalazł się na wierzchu. W opisach katalogowych dopiski są podane w oryginalnym brzmieniu, a zaznaczone są jedynie odstępstwa od podanych powyżej „zasad”.

Jeżeli chodzi o sygnatury, to podano je w formie zwyczajowo używanej w toruńskim archiwum i w literaturze. Numer po skrócie nazwy zespołu oznacza jednostkę archiwalną; dodatkowo w przypadku listów z Katalogu II podano numery stron w poszycie - odpowiednio pierwszej i ostatniej strony listu.

Podstawowym sposobem uwierzytelniania pisma były podpisy. Czasami wystarczył podpis Burgermeister und Rath daselbst, ale w większości przypadków podpisywano się nazwiskami z podaniem pełnionej funkcji, ewentualnie nazwy urzędu. Listy wystawiane przez rady miejskie były sygnowane przez burmistrza (proconsul, Burgermeister), jednego z rajców (consul), rzadziej sędziego (iudex, Richter), skarbnika (Kämerer) lub pisarza sporządzającego pis-

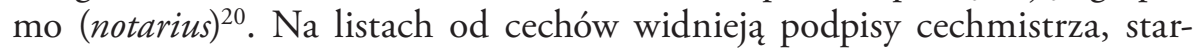
szych cechu (Alter, Eltesten) i ich zastępców (Kompan). Przedstawiciele gminy ewangelickiej podpisywali się jako starsi (seniores). W przypadku sądów podawano pełną nazwę instytucji lub stanowiska (das Königl[iche] Preuss[ische] StadtGerichte allhier, Ashocürt Adelich Creys Gericht), po czym następowały nazwiska. Ciekawą rzeczą jest, że gdy występuje kilka podpisów, to z różnic w barwie atramentu można wysnuć założenie o „krążeniu” czystopisu w celu jego akceptacji przez te osoby. Nazwiska figurują w stałej kolejności od lewej strony do prawej, ale niekiedy pozostawiano lukę - puste miejsce wystarczające na złożenie podpisu. Mimo starań, nie zawsze udało się odczytać występujące podpisy ze stuprocentową pewnością, szczególnie jeśli chodzi o ich końcówki, które często wyglądały jak zwykłe zawijasy.

Podobne zastrzeżenie należy mieć wobec nazwisk pojawiających się w treści listu. Poza tym do nazwisk zamężnych kobiet i wdów powszechnie dodawano końcówki „-in”, „-en” (np. Richterin); w regeście zachowano tę formę. Wszelkie nazwiska występujące w listach z założenia nie są odmieniane, chodziło o to, by przypadkiem nie narzucić fałszywego brzmienia.

19 Pełne nazwy serii brzmią następująco: 3. Briefe an den Rath. Vom fremdländischen Behörden; 3a. Briefe an den Rath. Von Königl[ichen] Preuss [ischen] Behörden; 5. Briefe an den Rath. Aus nichtpreussischen Städten; 7. Briefe an den Rath. Gesuche pp. Aus der Bürgerschaft; 16. Briefe an den Rath. Miscellanea.

20 Pojawia się też nazwa funkcji president (list nr 21 z Łobżenicy), najpewniej jest to określenie urzędującego burmistrza. 
Nazwy miejscowości w regeście są tłumaczone na język polski, a w nawiasie obok podaje się oryginalne brzmienie. Niezidentyfikowane pozostały miejscowości „Cotlen” i „Shlen” (list nr 18 z Łobżenicy) - żadne nazwy o takim i podobnym brzmieniu nie występowały w Stowniku geograficznym Królestwa Polskiego ani w żadnym leksykonie miejscowości Rzeszy Niemieckiej. Wszelkie nazwy osobowe i geograficzne w regeście i opisie katalogowym zostały zaznaczone pogrubionym drukiem.

W zasadzie nie ma problemów z datowaniem listów, ponieważ w każdym podaje się miejsce, dzień, miesiąc i rok wystawienia. Tylko w najstarszych z nich zastosowano ówczesny sposób podawania daty dziennej i miesięcznej, polegający na liczeniu dni między świętami kościelnymi. Pewien problem wystąpił z datacją listu nr 49 z Mirosławca. Otóż wymienione tam święto „Lichtumh” nie występowało w wykazie świąt w Chronologii polskiej. Natomiast w Handbuch der Historischen Chronologie des Deutschen Mittelalters und der Neuzeit H. Grotefenda wymieniono święto Liechtum w dniu św. Jana i św. Pawła (26 czerwca) ${ }^{21}$.

W występujących wśród zgromadzonych listów świadectwach dobrego urodzenia formularz, niezależnie od miasta, w którym je sporządzano, jest praktycznie taki sam. Również pewne charakterystyczne formuły mają prawie identyczne brzmienie. Być może świadczy to o jakimś rozpowszechnionym wzorcu, szablonie, wedle którego sporządzano tego typu dokumenty?

Wydaje się, że w formularzu tym można wyodrębnić siedem części składających się na protokół wstępny, treść właściwą i protokół końcowy (eschatokół):

I. Protokół wstępny:

1. Intytulacja - wymienienie nazwy wystawcy dokumentu, np. Burgermeister und Rath der...;

II. Treść właściwa:

2. Promulgacja - oświadczenie woli rady o wystawieniu dokumentu;

3. Narracja - przedstawienie okoliczności prowadzących do powstania listu; prośba interwenienta(-ów), przysięga i oświadczenia świadków i samego zainteresowanego (data urodzenia lub chrztu, rodzice, niekiedy dziadkowie);

4. Dyspozycja - decyzja rady o wystawieniu świadectwa na podstawie przytoczonych zeznań i własnej wiedzy oraz prośba o zawierzenie podanym informacjom;

21 H. Grotefend, Handbuch der Historischen Chronologie des Deutschen Mittelalters und der Neuzeit, Hannover 1872, s. 89. 
5. Korroboracja - opisanie sposobu uwierzytelnienia listu (pieczęć, podpisy);

III. Eschatokół:

6. Datacja - podanie miejsca i daty wystawienia listu;

7. Podpisy - własnoręczne podpisy członków organu wystawiającego, brak jakichkolwiek list świadków.

Podobnym formularzem posługiwano się przy sporządzaniu listów cechowych. One również zawierały intytulację, promulgację, korroborację, datację i podpisy, lecz w narracji podawano informację o zakończeniu nauki zawodu przez okaziciela i wypełnieniu przez niego wszystkich związanych z tym obowiązków. Oczywiście, nie wszystkie części formularza musiały znajdować się w tekście listu. W zależności od potrzeb niektóre pomijano lub znacznie skracano ${ }^{22}$.

O formularzu tego rodzaju nie można mówić w przypadku korespondencji z Katalogu II. Ma ona charakter typowo urzędowy, doraźny i coraz bardziej masowy. Listy cechowe były jednak szczególniejszym rodzajem pisma - to tak, jakby porównywać podanie do urzędu ze świadectwem ukończenia szkoły. Stałymi elementami w tej korespondencji urzędowej były jedynie zwroty grzecznościowe i układ strony. Pismo rozpoczynał ozdobnie wykonany zwrot do adresata (Wohllöblichen Wohledeln Herren Bürgermeister und Rathmanne...). Poniżej znajdowała się treść sprawy: dany urząd zwraca się z prośbą o podjęcie działania w sprawie, a na koniec zapewnia o swej życzliwości i woli współpracy. Pod tekstem mieściły się miejsce i data wystawienia oraz podpisy. Tak więc układ bardzo przypomina współczesne pisma urzędowe.

Regesty i opisy listów ułożono alfabetycznie według polskich nazw miejscowości, a w ich obrębie chronologicznie. Ewentualne załączniki z reguły znajdują się po piśmie głównym; jeżeli jednak ich data sporządzenia jest wcześniejsza, występują przed pismem głównym. Nadany układ przedstawia wykaz umieszczony przed częścią katalogową artykułu.

Katalog listów sporządzono w myśl postulatów zawartych w artykule Andrzeja Radzimińskiego i Janusza Tandeckiego Projekt wytycznych $w$ sprawie przygotowania do druku katalogu dokumentów i listów oraz w broszurze Józefa Płochy Wytyczne opracowania dokumentów pergaminowych i papierowych ${ }^{23}$. W nagłówku opisu katalogowego znajduje się kolejny numer listu, poniżej

22 K. Maleczyński, M. Bielińska, A. Gąsiorowski, Dyplomatyka wieków średnich, Warszawa 1971, s. 23-24.

23 A. Radzimiński, J. Tandecki, Projekt wytycznych w sprawie przygotowania do druku katalogu dokumentów i listów, Archeion, t. 93, 1994, s. 39-47; Wytyczne opracowania dokumentów pergaminowych i papierowych, oprac. J. Płocha, Warszawa-Łódź 1985. 
data i miejsce jego wystawienia w języku polskim, a obok - w oryginale. Pod regestem umieszczono sześć punktów opisujących fizyczny wygląd dokumentu:

1. Stwierdzenie, czy to oryginał, czy kopia; rodzaj materiału, na którym sporządzono list (pergamin/papier); wymiary w mm (szerokość $\times$ wysokość + zakładka na pieczęć lub dla bifolium: szerokość $\times$ wysokość + szerokość $\times$ × wysokość); język (niemiecki, łacina, polski).

2. Stan zachowania, ewentualne uszkodzenia; pieczęć - rodzaj, wygląd; znaki wodne - wygląd, pochodzenie.

3. Napisy dorsalne - przytoczone w oryginale:

- adres, inne dopiski nadawcy lub poczty [A];

- dorsalia właściwe, powstałe u odbiorcy [B];

- noty kancelaryjne z objaśnieniem położenia na stronie $[\mathbf{C}]$;

- dopiski archiwalne [D].

4. Wydawnictwa źródłowe, w których dany list opublikowano drukiem.

5. Aktualna sygnatura archiwalna.

6. Uwagi; tu również przytoczono w oryginalnym brzmieniu podpisy wystawców wraz z podanymi w liście funkcjami.

WYKAZ LISTów

\begin{tabular}{|c|l|c|l|}
\hline $\begin{array}{c}\text { Numer listu } \\
\text { W KATAlogu }\end{array}$ & \multicolumn{1}{|c|}{ Miasto } & $\begin{array}{c}\text { RoK } \\
\text { WYSTAWIEnia }\end{array}$ & \multicolumn{1}{|c|}{$\begin{array}{c}\text { Sygnatura } \\
\text { ARCHIWALNA }\end{array}$} \\
\hline 1 & Czaplinek & 1721 & Kat. III, 5145a \\
\hline 2 & Czaplinek & 1735 & Kat. III, 5404a \\
\hline 3 & Czaplinek & 1736 & Kat. III, 5414 \\
\hline 4 & Czaplinek & 1748 & Kat. III, 5612a \\
\hline 5 & Czaplinek & 1756 & Kat. III, 5741 \\
\hline 6 & Człopa & 1771 & Kat. III, 5928 \\
\hline 7 & Jastrowie & 1746 & Kat. III, 5579 \\
\hline 8 & Jastrowie & 1752 & Kat. III, 5654 \\
\hline 9 & Jastrowie & 1778 & Kat. II, I-3433/135 \\
\hline 10 & Jastrowie & 1787 & Kat. II, I-3322/485 \\
\hline 11 & Jastrowie & 1787 & Kat. II, I-3322/477 \\
\hline 12 & Jastrowie & 1787 & Kat. II, I-3322/481 \\
\hline 13 & Jastrowie & & Kat. II, I-3322/483 \\
\hline & & &
\end{tabular}




\begin{tabular}{|c|c|c|c|}
\hline $\begin{array}{l}\text { NuMER LISTU } \\
\text { W KATALOGU }\end{array}$ & Miasto & $\begin{array}{c}\text { RoK } \\
\text { WYSTAWIENIA }\end{array}$ & $\begin{array}{c}\text { SYGNATURA } \\
\text { ARCHIWALNA }\end{array}$ \\
\hline 14 & Jastrowie & 1787 & Kat. II, I-3322/475 \\
\hline 15 & Jastrowie & 1789 & Kat. II, I-3324/81 \\
\hline 16 & Krajenka & 1799 & Kat. III, 6080c \\
\hline 17 & Łobżenica & 1695 lub 1697 & Kat. III, 4803 \\
\hline 18 & Łobżenica & 1717 & Kat. III, 6361 \\
\hline 19 & Łobżenica & 1720 & Kat. III, 5117 \\
\hline 20 & Łobżenica & 1720 & Kat. III, 5143 \\
\hline 21 & Łobżenica & 1729 & Kat. III, 6365 \\
\hline 22 & Łobżenica & 1732 & Kat. II, I-3340/323 \\
\hline 23 & Toruń/Łobżenica & 1743 & Kat. II, I-3410/31 \\
\hline 24 & Łobżenica & 1749 & Kat. III, 5626/1 \\
\hline 25 & Łobżenica & 1749 & Kat. III, 5626/2 \\
\hline 26 & Łobżenica & 1754 & Kat. III, 5722 \\
\hline 27 & Łobżenica & 1765 & Kat. II, I-3421/114 \\
\hline 28 & Łobżenica & 1767 & Kat. II, I-3343/217 \\
\hline 29 & Łobżenica & 1767 & Kat. II, I-3513/349 \\
\hline 30 & Łobżenica & 1768 & Kat. II, I-3343/439 \\
\hline 31 & Łobżenica & 1771 & Kat. II, I-3344/315 \\
\hline 32 & Łobżenica & 1773 & Kat. II, I-3316/613 \\
\hline 33 & Łobżenica & 1773 & Kat. II, I-3316/689 \\
\hline 34 & Łobżenica & 1774 & Kat. II, I-3317/181 \\
\hline 35 & Łobżenica & 1774 & Kat. II, I-3317/197 \\
\hline 36 & Łobżenica & 1774 & Kat. II, I-3317/239 \\
\hline 37 & Łobżenica & 1774 & Kat. II, I-3317/241 \\
\hline 38 & Łobżenica & 1774 & Kat. II, I-3317/251 \\
\hline 39 & Łobżenica & 1774 & Kat. II, I-3317/285 \\
\hline 40 & Łobżenica & 1774 & Kat. II, I-3317/295 \\
\hline 41 & Łobżenica & 1775 & Kat. II, I-3311/311 \\
\hline 42 & Łobżenica & 1782 & Kat. II, I-3321/9 \\
\hline 43 & Łobżenica & 1782 & Kat. II, I-3321/13 \\
\hline 44 & Łobżenica & 1782 & Kat. II, I-3321/125 \\
\hline
\end{tabular}




\begin{tabular}{|c|c|c|c|}
\hline $\begin{array}{l}\text { NuMER LISTU } \\
\text { W KATALOGU }\end{array}$ & Miasto & $\begin{array}{c}\text { RoK } \\
\text { WYSTAWIENIA }\end{array}$ & $\begin{array}{l}\text { SYGNATURA } \\
\text { ARCHIWALNA }\end{array}$ \\
\hline 45 & Łobżenica & 1782 & Kat. II, I-3313/123 \\
\hline 46 & Łobżenica & 1784 & Kat. II, I-3313/99 \\
\hline 47 & Toruń/Łobżenica & 1791 & Kat. II, I-3441/183 \\
\hline 48 & Toruń/Łobżenica & 1792 & Kat. II, I-3442/359 \\
\hline 49 & Mirosławiec & 1402 & Kat. III, 4531 \\
\hline 50 & Mirosławiec & 1727 & Kat. III, 5258 \\
\hline 51 & Mirosławiec & 1727 & Kat. III, 5266 \\
\hline 52 & Mirosławiec & 1736 & Kat. III, 5411a \\
\hline 53 & Mirosławiec & 1770 & Kat. II, I-3344/169 \\
\hline 54 & Mirosławiec & 1771 & Kat. II, I-3311/29 \\
\hline 55 & Mirosławiec & 1782 & Kat. III, 6003 \\
\hline 56 & Mirosławiec & 1784 & Kat. III, 6019/1 \\
\hline 57 & Mirosławiec & 1784 & Kat. III, 6019/2 \\
\hline 58 & Mirosławiec & 1788 & Kat. II, I-3313/483 \\
\hline 59 & Mirosławiec & 1789 & Kat. II, I-3314/85 \\
\hline 60 & Mirosławiec & 1791 & Kat. II, I-3347/501 \\
\hline 61 & Mrocza & 1724 & Kat. III, 5203 \\
\hline 62 & Nakło nad Notecią & 1404 & Kat. III, 4184 \\
\hline 63 & Nakło nad Notecią & 1777 & Kat. II, I-3311/411 \\
\hline 64 & Nakło nad Notecią & 1785 & Kat. II, I-3346/597 \\
\hline 65 & Piła & 1608 & Kat. III, 4643 \\
\hline 66 & Piła & 1774 & Kat. II, I-3427/661 \\
\hline 67 & Piła & 1776 & Kat. II, I-3316/211 \\
\hline 68 & Piła & 1776 & Kat. II, I-3318/209 \\
\hline 69 & Piła & 1781 & Kat. II, I-3320/511 \\
\hline 70 & Piła & 1792 & Kat. II, I-3347/663 \\
\hline 71 & Piła & 1793 & Kat. II, I-3314/691 \\
\hline 72 & Piła & 1793 & Kat. II, I-3314/697 \\
\hline 73 & Sępólno Krajeńskie & 1407 & Kat. III, 4247 \\
\hline 74 & Sępólno Krajeńskie & 1764 & Kat. II, I-3420/357 \\
\hline 75 & Tuczno & 1747 & Kat. III, 5607 \\
\hline
\end{tabular}


KONKORDANCJA - KAT. II

\begin{tabular}{|l|l|l|l|}
\hline \multicolumn{1}{|c|}{$\begin{array}{c}\text { SygnATURA/ } \\
\text { /STRONA }\end{array}$} & NR KATALOG. & \multicolumn{1}{|c|}{ Miasto } & RoK \\
\hline I-3311/29 & 54 & Mirosławiec & 1771 \\
\hline I-3311/311 & 41 & Łobżenica & 1775 \\
\hline I-3311/411 & 63 & Nakło & 1777 \\
\hline I-3313/121 & 46 & Łobżenica & 1784 \\
\hline I-3313/483 & 58 & Mirosławiec & 1788 \\
\hline I-3314/85 & 59 & Mirosławiec & 1789 \\
\hline I-3314/691 & 71 & Piła & 1793 \\
\hline I-3314/697 & 72 & Piła & 1793 \\
\hline I-3316/211 & 67 & Piła & 1776 \\
\hline I-3316/613 & 32 & Łobżenica & 1773 \\
\hline I-3316/689 & 33 & Łobżenica & 1773 \\
\hline I-3317/181 & 34 & Łobżenica & 1774 \\
\hline I-3317/197 & 35 & Łobżenica & 1774 \\
\hline I-3317/239 & 36 & Łobżenica & 1774 \\
\hline I-3317/241 & 37 & Łobżenica & 1774 \\
\hline I-3317/251 & 38 & Łobżenica & 1774 \\
\hline I-3317/285 & 39 & Łobżenica & 1774 \\
\hline I-3317/295 & 40 & Łobżenica & 1774 \\
\hline I-3318/209 & 68 & Piła & 1776 \\
\hline I-3320/511 & 69 & Piła & 1781 \\
\hline I-3321/9 & Łobżenica & 1782 \\
\hline I-3321/13 & 43 & Łobżenica & 1782 \\
\hline I-3321/123 & Łobżenica & 1782 \\
\hline I-3321/125 & 13 & Łobżenica & 1782 \\
\hline I-3322/475 & Jastrowie & 1787 \\
\hline I-3322/477 & Jastrowie & 1787 \\
\hline I-3322/481 & Jastrowie & 1787 \\
\hline I-3322/483 & Jastrowie & 1787 \\
\hline I-3322/485 & & \\
\hline
\end{tabular}




\begin{tabular}{|l|c|l|l|}
\hline \multicolumn{1}{|c|}{$\begin{array}{c}\text { Sygnatura/ } \\
\text { /strona }\end{array}$} & NR Katalog. & \multicolumn{1}{|c|}{ Miasto } & RoK \\
\hline I-3324/81 & 15 & Jastrowie & 1789 \\
\hline I-3340/323 & 22 & Łobżenica & 1732 \\
\hline I-3343/217 & 28 & Łobżenica & 1767 \\
\hline I-3343/439 & 30 & Łobżenica & 1768 \\
\hline I-3344/169 & 53 & Mirosławiec & 1770 \\
\hline I-3344/315 & 31 & Łobżenica & 1771 \\
\hline I-3346/597 & 64 & Nakło & 1785 \\
\hline I-3347/501 & 60 & Mirosławiec & 1791 \\
\hline I-3347/663 & 70 & Piła & 1792 \\
\hline I-3410/31 & 23 & Toruń/Łobżenica & 1743 \\
\hline I-3420/357 & 74 & Sępólno Kraj. & 1764 \\
\hline I-3421/114 & 27 & Łobżenica & 1765 \\
\hline I-3427/661 & 66 & Piła & 1774 \\
\hline I-3433/135 & 9 & Jastrowie & 1778 \\
\hline I-34411/183 & 47 & Toruń/Łobżenica & 1791 \\
\hline I-3442/359 & 48 & Toruń/Łobżenica & 1792 \\
\hline I-3513/349 & 29 & Łobżenica & 1767 \\
\hline
\end{tabular}

KONKORDANCJA - KAT. III

\begin{tabular}{|l|c|l|l|}
\hline \multicolumn{1}{|c|}{ Sygnatura } & Nr Katalog. & \multicolumn{1}{c|}{ Miasto } & Roк \\
\hline 4184 & 62 & Nakło & 1404 \\
\hline 4247 & 73 & Sępólno Kraj. & 1407 \\
\hline 4531 & 49 & Mirosławiec & 1402 \\
\hline 4643 & 65 & Piła & 1608 \\
\hline 4803 & 17 & Łobżenica & 1697 \\
\hline 5117 & 19 & Łobżenica & 1720 \\
\hline 5143 & 20 & Łobżenica & 1720 \\
\hline $5145 \mathrm{a}$ & 1 & Czaplinek & 1721 \\
\hline
\end{tabular}




\begin{tabular}{|l|c|l|l|}
\hline \multicolumn{1}{|c|}{ Sygnatura } & NR KatalOG. & \multicolumn{1}{c|}{ Miasto } & ROK \\
\hline 5203 & 61 & Mrocza & 1724 \\
\hline 5258 & 50 & Mirosławiec & 1727 \\
\hline 5266 & 51 & Mirosławiec & 1727 \\
\hline $5404 a$ & 2 & Czaplinek & 1735 \\
\hline $5411 \mathrm{a}$ & 52 & Mirosławiec & 1736 \\
\hline 5414 & 3 & Czaplinek & 1736 \\
\hline 5579 & 7 & Jastrowie & 1746 \\
\hline 5607 & 75 & Tuczno & 1747 \\
\hline $5612 \mathrm{a}$ & 4 & Czaplinek & 1748 \\
\hline $5626 / 1$ & 24 & Łobżenica & 1749 \\
\hline $5626 / 2$ & 25 & Łobżenica & 1749 \\
\hline 5654 & 8 & Jastrowie & 1752 \\
\hline 5722 & 26 & Łobżenica & 1754 \\
\hline 5741 & 5 & Czaplinek & 1756 \\
\hline 5928 & 6 & Człopa & 1771 \\
\hline 6003 & 55 & Mirosławiec & 1782 \\
\hline $6019 / 1$ & 56 & Mirosławiec & 1784 \\
\hline $6019 / 2$ & 57 & Mirosławiec & 1784 \\
\hline $6080 \mathrm{c}$ & 16 & Krajenka & 1799 \\
\hline 6361 & 18 & Łobżenica & 1717 \\
\hline 6365 & 21 & Łobżenica & 1729 \\
\hline
\end{tabular}


NR 1

1721, 20 X Czaplinek Geschehen zu Tempelburg, den 20 Octob[e]r: des ein tausend siebenhundert und ein und zwanzigsten Jahres nach Christi geburth

Burmistrz, sędzia i rada królewskiego pruskiego miasta Czaplinek wydają na prośbę mistrza Friedricha Olböter - mieszczanina i starszego cechu kuśnierzy; świadectwo dobrego urodzenia dla jego syna Johanna Olböter dziecka Friedricha Olböter i Dorothei Cathariny Mittelstätin, urodzonego 25 czerwca 1707 r., narodowości niemieckiej, ochrzczonego w obecności: mistrza Laurentza Daugs - mieszczanina i starszego cechu rzeźników, mistrza Johanna Rahz - mieszczanina i sukiennika oraz Anny Marii Dibbelin - małżonki mistrza Jacoba Olböter - mieszczanina i starszego cechu rzeźników; co potwierdzili świadkowie. Dziadkami Johanna Olböter ze strony ojca byli: Johann Olböter i Anna Schulzen, a ze strony matki: Andreas Mittelstät - pastor w Cieszynie (Teschendorfe) i Barbara Broczen.

1. Oryginał, perg., $514 \times 340+54 \mathrm{~mm}$; niem.

2. Stan dobry; przywieszona pieczęć miejska: plica, wstążki zielona i czerwona, pieczęć okrągła, woskowa, brązowa, śr. $33 \mathrm{~mm}$, w drewnianej puszce; wizerunek bramy miejskiej z dwoma basztami i sylwetką czapli między nimi, na obwodzie tekst "SIGILVM CIVITATIS TEMPELBURGENSIS”. Zob. HMW, B-93, s. 325.

3. [D] 5145a; Kürschner Geburtsbrief Johann Olböter Tempelburg, 20-10. 1721 .

4. -

5. Kat. III, 5145a.

6. Podpisów brak.

NR 2

1735, 26 II Czaplinek

Gegeben Tempelburg den 26-e February 1735

Burmistrz, sędzia i rada miasta Czaplinek poświadczają dobre urodzenie Conrada Friedricha Zimmermanna [rzeźnika], który na mocy patentu króla pruskiego z 6 sierpnia 1732 r. może być przyjmowany do cechów. 
1. Kopia, pap., formularz drukowany; $417 \times 332 \mathrm{~mm}$; niem.

2. Stan niezbyt dobry, na zgięciach przetarcia, brzegi postrzępione; pieczęć papierowo-lakowa, popękana, okrągła, śr. $34 \mathrm{~mm}$, wizerunek jak w liście nr 1, dwa okrągłe stemple drukowane (1. orzeł pruski, na obwodzie tekst „KÖNIGLICH. PREUSSISCHES ARMEN DIRECTORIUM”; 2. cyfra królewska - inicjały FR zwieńczone koronami tworzące stylizowany krzyż równoramienny) i drukowane godło pruskie (orzeł pruski z mieczem i berłem w szponach, ponad nim korona); znak wodny niewyraźny.

3. [B] Geburts Brief Conrad Friedrich Zim [m]ermann ein Fleischer illat [um] d[en] 14 Apr[il]1752; [D] 5404a; Tempelburg Februar 1735; Febr[uar] 35.

4. -

5. Kat. III, 5404a.

6. Burgermeistere Richter und Rath sieselbst. Friderici, Consul; Johann Boys, Iudex. Formularz tożsamy z listem nr 3, dodatkowo nagłówek COPIA.

NR 3

1736, 1 II Czaplinek

Gegeben Tempelburg den 1-te Febr[uar] 1736

Burmistrz i rada miasta Czaplinek poświadczają dobre urodzenie Heinricha Block [sukiennika], który na podstawie patentu króla pruskiego z 6 sierpnia 1732 r. może być przyjmowany do cechów.

1. Oryginał, pap., formularz drukowany, $435 \times 350 \mathrm{~mm}$; niem.

2. Stan dobry, ślady złożenia, brzegi postrzępione; pieczęć miejska lakowa, czerwona, okrągła, śr. $34 \mathrm{~mm}$, wizerunek jak w liście nr 1. Dwa stemple drukowane i drukowany orzeł pruski jak w liście nr 2; znak wodny: „kwiat w wazonie” - nierozpoznany.

3. [B] Geburhts-Brief Heinrich Block einen Tuchmacher, illat[um] d[en] 20 Juny 1755; [D] 5414; 1 Febr[uar] 1736 Heinrich Block (Tuchmacher), Tempelburg.

4. -

5. Kat. III, 5414.

6. Burgermeister und Rats. Friderici; Cons[ul] dirig[ens], Cuno; Cämerer. 
NR 4

1748, 7 XII Czaplinek

Tempelburg d[en] 7ten Decemb[e]r 1748

Burmistrz i rajcy królewskiego pruskiego miasta Czaplinek na Pomorzu wydają na prośbę Samuela Zimmermanna - mieszczanina i rzeźnika, świadectwo dobrego urodzenia dla jego syna Johanna Christiana Zimmermanna (wyuczonego na sukiennika), co potwierdzili dwaj mieszczanie: Peter Fancke - sukiennik i Michael Kumm - piekarz. Zaświadczyli oni, że J.Ch. Zimmermann jest synem Samuela Zimmermanna i Marii Elisabeth Richterin; został ochrzczony w czaplinieckim kościele przez pastora Schiracha 3 listopada 1726 r. w obecności Johanna Jacoba Boys - sędziego miejskiego, Christopha Friderici - burmistrza i Sophii Haacken - małżonki inspektora Gabriela Dumck; a jego dziadkami ze strony ojca byli: Johann Zimmermann - leśnik królewski w Starym Drawsku (Draheim - Drahim) i Anna Catharina Wreicken - córka mieszczanina i ślusarza z Pyrzyc (Pyritz), a ze strony matki: Johann Christoph Richter - mieszczanin i starszy cechu kowali miedzi w Kołobrzegu (Colberg) i Anna Catharina Reinhardten - córka mieszczanina i kowala miedzi w Czaplinku, Friedricha Reinhardt.

1. Oryginał, pap., $413 \times 331 \mathrm{~mm}$; niem.

2. Stan dobry; pieczęć papierowo-lakowa, okrągła, śr. $34 \mathrm{~mm}$, wizerunek jak w liście nr 1; znaku wodnego brak.

3. [B] Geburts-Brief Johann Christian Zim[m]ermann, eines Tuchmachers. lect[um] d[en] 2 Nov[em]b[e]r 1753; [D] 5612a; Tempelburg, Dec[em]b[e]r. 1748.

4. -

5. Kat. III, 5612a.

6. Burgermeister Richter und Rath dieselbst. GJ [?] Kirstenius, Cons[ul] dir[igens] et Iudex.

NR 5

1756, 1 II Czaplinek Gegeben Tempelburg den 1-ten Febr[uar] 1756

Burmistrz i rada miasta Czaplinek poświadczają dobre urodzenie Gottfriedta Block [sukiennik], który na podstawie patentu króla pruskiego z 6 sierpnia 1732 r. może być przyjmowany do cechów. 


\section{Krystian Chyrkowski}

1. Kopia, pap., formularz drukowany, $422 \times 350 \mathrm{~mm}$; niem.

2. Stan dobry, brzegi postrzępione; pieczęć miejska lakowa, czerwona, okrągła, śr. $34 \mathrm{~mm}$; pieczęcie i znak wodny („kwiat w wazonie”) tożsame jak w liście nr 3.

3. [B] illat[um] d[en] 10. Octob[e]r 1770;; [D] 5741; Tempelburg. Februar 1756. Geburtsbrief der Gottf[ried] Block.

4. -

5. Kat. III, 5741.

6. Burgermeister und Rath. Friderici, Cons[ul] dirig[ens]; Cuno, Cämerer. Formularz tożsamy z listem nr 3, dodatkowo nagłówek COPIA.

NR 6

1771, 15 III Człopa

(...) gegeben in Hochfurstl[ichen] Polnischen Stadt Schloppa. 15 März 1771

Burmistrz i rada polskiego miasta Człopa wydają na prośbę mieszczan: Jacoba Ferber i Samuela Röhl [?] świadectwo dobrego urodzenia dla Christiana Fridricka Wolffschläger, trzeciego dziecka (z pięciorga) Christopha Wolffschläger - mieszczanina, rajcy w Barlinku (Berlinschen) i Charlotty Bleymann.

1. Oryginał, pap., $400 \times 248 \mathrm{~mm}$; niem.

2. Stan dobry, ślady złożenia, brzegi postrzępione, niebieskie podkreślenia w tekście; pieczęć miejska, papierowo-lakowa, okrągła, śr. $34 \mathrm{~mm}$, wizerunek kartusza z koroną, trzema gwiazdami i półksiężycem. Zob. HMW, B-104, s. 326-327. Znak wodny: ,goździk” - nierozpoznany.

3. [B] illat [um] d[en] 3 Maii 1771; [D] 5928; 15 Maerz 1771 Christian Friedr. Wolffschlagen [?]. Schloppa.

4. -

5. Kat. III, 5928.

6. Burgermeister und Rath, Mlüdick [?] Consul dirigens. 
NR 7

1746, 21 IV Jastrowie Geschehn Jastro d[en] 21 April im Jahr Christi Ein Tausendt Sieben Hundert Sechs und Viertzig

Burmistrz i rada królewskiego polskiego miasta Jastrowia wydają Simonowi Jaster; kupcowi handlującemu jedwabiem, synowi Simona Jaster - kowala i rolnika z polskiej (królewskiej) wsi Sypniewo (Zipno) i Sophii Stimen; ochrzczonego w kościele w Sypniewie 14 sierpnia 1713 r. w obecności Petera Lütcke i Petera Reünspis - tamtejszych rolników; na jego prośbę świadectwo dobrego urodzenia, co potwierdzili Johann Spiecker - mieszczanin i starszy cechu oraz Jacob Schultzen - mieszczanin i szlachcic. Dziadkami Simona Jaster ze strony ojca byli: Johann Jaster - kowal i rolnik z Sypniewa i Anna Dügen - córka rolnika z Sypniewa, a ze strony matki George Stim - sołtys w królewskiej wiosce Nadarzyce (Rederitz) i Sophia Klawonen córka sołtysa z Nadarzyc.

1. Oryginał, perg., $446 \times 372+50 \mathrm{~mm}$; niem.

2. Stan dobry; przywieszona pieczęć miejska: plica, zielona wstążka, pieczęć okrągła, woskowa, zielona, śr. $40 \mathrm{~mm}$, w metalowej puszce, na obwodzie tekst „SIGILLVM CIVITATIS IASTROVIAE 1697”. Wizerunek kiści winogron. Por. HMW, B-205, s. $343^{24}$.

3. [B] Geburths-brieffSimon Jaster ein Seydenkrahmer. illat [um] d[en] 25 April 1746; [D] 5579; 21. April 1746 Jastra.

4. -

5. Kat. III, 5579.

6. Matthias Gäde, Proconsul; Carl Dethaus Lembcke, Consul; Johann Wegner, Notarius Juratus Jastroviensis.

24 Zob. też M. Gumowski, Pieczęcie i herby miast pomorskich, Toruń 1939 (dalej: PiHMPom.), s. 93. 


\section{NR 8}

1752, 27 V Jastrowie

So geschehen Jastrow, den 27-te May das Ein Tausend Sieben Hundert zwey und funffzig- ten Jahren

Burmistrz i rada królewskiego miasta Jastrowie w województwie poznańskim wydają na prośbę Marii Körnerin zd. Wacholtz [pochodzącej z Lędyczka (Landeck)], wdowie po Johannie Körner - sekretarzu królewskim, masztalerzu i burmistrzu Jastrowia; w obecności dwóch świadków: Daniela Tytz - sędziego miejskiego i Jacoba Tröhlieh - asesora rady; świadectwo dobrego urodzenia dla jej syna Johanna Friedricha Körner [kupca] - urodzonego 5 marca 1728 r., ochrzczonego w obecności Michaela Tytz - członka rady i zm. Christopha Ryptow - byłego burmistrza Jastrowia. Dziadkami J.F. Körner ze strony ojca byli: zm. Daniel Körner - były burmistrz Jastrowia i Elisabeth Welsen z Czechynia (Zechendorf), a ze strony matki Peter Wacholz z Lędyczka i Maria Schrancken - córka burmistrza ze Złocieńca (Falkenburg) w Nowej Marchii.

1. Oryginal, pap., $492 \times 371 \mathrm{~mm}$; niem.

2. Stan dość dobry, przetarcia i postrzępienia brzegów; pieczęć miejska papierowo-lakowa, czerwona, owalna, śr. $38 \times 42 \mathrm{~mm}$, wizerunek i legenda jak w liście nr 7; znaki wodne: 1.k. napis „I HONIG”, 2.k. filigran "Strassburg” - nierozpoznane.

3. [B] Geburts-Brief des Johann Friedrich Kome [przekreślone] Körner eines Kauffmanns. lect[um] d[en] 22 Jun[i] 1753; [D] 5654; 27 Mai 1752 Jastrow.

4. -

5. Kat. III, 5654.

6. Matthias Gäde, Proconsul; Michael Tytz, Consul; Paulus Keler, Not[arius] Iuratus p[u]bl[ici] Jastroviensis.

\section{NR 9}

1778, 27 XI Jastrowie

Jastrow den 27-e Nov[em]b[e]r. 1778

Sąd miejski w Jastrowiu prosi magistrat toruński o podjęcie działań w celu odzyskania kwot pieniężnych po zmarłych: kupiec Johann Fendler Wittere oraz kupiec i handlarz suknem Schmid Wittzze [?], którzy figurowali na li- 
ście dłużników zmarłego Daniela Tytz - burmistrza Jastrowia, w celu przyspieszenia podziału spadku po nim między jego dzieci.

1. Oryginał, pap., bifolium, $209 \times 353+217 \times 353 \mathrm{~mm}$; niem.

2. Stan dobry, ślady złożenia; 2 stemple drukowane, pieczęć miejska papierowo-lakowa, czerwona, owalna, śr. $38 \times 42 \mathrm{~mm}$, wizerunek i legenda jak w liście nr 7. Filigrany: 1.k. „HASSER | N M | NI”, 2.k. stylizowany orzeł pruski w koronie z berłem i jabłkiem na szponach - oba nierozpoznane.

3. [D] 135-136, 165-166.

4. -

5. Kat. II, I-3433; s. $135+165$.

6. des Königl[iche] Preuß[ische] Stadt Gerichte allhier | Dieshels | Königl[iche] Preuß[ische] Justitz Beamten und Justitz Commishons

Przytoczenie oświadczenia mieszczanina i sukiennika jastrowskiego Frieda Boht odnośnie do ustalenia ostatecznego terminu zwrotu długu przez farbiarza Lüschnera, którym ma być godzina 8 rano 11 czerwca [1787 r.].

1. Kopia, pap., bifolium, $195 \times 336 \mathrm{~mm}$, niem.

2. Stan dobry, ślady złożenia; pieczęci brak; znak wodny: korona zwieńczona krzyżem - nierozpoznany.

3. [C] Copia. Document: Insinuat: [gp], An den Färber Lüschner gegenwärtig zu Thoren $[\mathrm{dl}] ;$ [D] 485.

4. -

5. Kat. II, I-3322; s. $485+$ brak.

6. Königl[iche] Westpr[eußische] Stadt Gerichte | Sisty; [luka] NRvTrotter. 


\section{Str. 1}

Przytoczenie oświadczenia Żyda złotowskiego [Schutz Jude (...) aus Flatow] Abrahama Jacob odnośnie do ustalenia ostatecznego terminu zwrotu długu przez farbiarza Lüschnera, którym ma być godzina 8 rano 11 czerwca [1787 r.].

\section{Str. 2}

Kopia oświadczenia Żyda Abrahama Jacob ze Złotowa (Flatow) o rodzaju i wysokości zadłużenia względem niego farbiarza Lüschnera.

\section{Str. 2-3}

Kopia oświadczenia Żyda złotowskiego Abrahama Jacob o tym, jak dowiedział się o miejscu pobytu farbiarza Lüschnera, i prośba o zajęcie jego dwóch koni do czasu otrzymania większej ilości informacji i zmniejszenia zadłużenia.

1. Kopia, pap., bifolium, $193 \times 334+178 \times 334 \mathrm{~mm}$; niem.

2. Stan dobry, ślady złożenia; pieczęć miejska mniejsza - zabezpieczająca, złamana, lakowa, czarna, okrągła, śr. ok. $22 \mathrm{~mm}$, na otoku napis „SIGIL[LUM] · MINUS CIV[ITATIS] • IASTROVIE • AD 17[83 ?]”25; znak wodny: 1.k. litery „ICM”, 2.k. ryba w stylizowanym otoku, powyżej wkomponowany herb Elbląga - nierozpoznane ${ }^{26}$.

3. [A] Ad den Färber Lüschner gegenwärtig zu Thoren; [C] Str. 1: Stam. res. ad acta [?] [gl]; An den Färber Lüschner gegenwärtig zu Thoren [dl]; Str. 2: Copia [gl]; Actum Jastrow den 14 May 1787 [g]; [D] $477 \div 479$.

4. -

5. Kat. II, I-3322; s. 477-480.

6. Str. 1: Sechs; Sisty; [luka] NRvTrotter;

Str. 2: Abraham Jacob; Sechs [oba podpisy wykonane jedną ręką];

Str. 3: Sechs; Abraham Jacob [oba podpisy wykonane jedną ręką].

25 Lekcja niepewna, być może jest to pieczęć, o której wspomina M. Gumowski, PiHMPom., s. 93 (a za nim M. Adamczewski, HMW, B-206, s. 343), której legenda jest przedstawiona jako „SIGILLVM · MINUS · CIV · IASTROVIE ANNO 1755”.

26 Inicjały ICM stosowano w latach $1751-1782$ w papierni w Wąsoszu. Por. F. Pabich, Papiernie nadnoteckie, s. 292; tenże, Dzieje ztotowskiej papierni w Wasoszu, Przegląd Papierniczy, t. 41, nr 5, 1985, s. 186-188. Jednak motyw ryby i herbu Elbląga mogą wskazywać też na którąś z papierni znad Zatoki Gdańskiej. 


\section{Str. 1}

Przytoczenie oświadczenia sukiennika i mieszczanina z Jastrowia Frieda Boht, że farbiarz Lüschner ma u niego dług i wyznacza termin jego zwrotu do 11 czerwca $1787 \mathrm{r}$.

\section{Str. 2}

Odpis oświadczenia mieszczanina i sukiennika jastrowskiego Frieda Boht, w którym wyjaśnia okoliczności powstania wierzytelności względem niego farbiarza Simona Gottlieba Lüschnera i wzmiankuje o przekazaniu pisemnego zobowiązania [obligatio] jako podstawy postępowania.

1. Kopia, pap., bifolium, $195 \times 338+195 \times 338$ mm; niem.

2. Stan dobry, ślady złożenia; pieczęć zabezpieczająca - patrz list nr 11; znaki wodne: 1.k. orzeł pruski z berłem i mieczem w szponach, 2.k. litery „ICM” w stylizowanej obwódce - oba nierozpoznane ${ }^{27}$.

3. [A] An den Färber Simon Lüschner gegenwärtig zu Thoren; [C] Str. 1: Stenp.[?] res: ad acta [g]; An den Färber Lüschner gegenwärtig zu Thoren [d]; Str. 2: Copia. [lg]; Actum Jastrow d[en] 14 May 1787 [pg]; [D] 481 $\div 482 ; 491$.

4. -

5. Kat. II, I-3322; s. $481+492$.

6. Str. 1: Königl[iche] Westpr[eußische] Stadt:Gerichte |Sechs; Sisty; [luka] NRvTrotter;

Str. 2: Fried Boht; Sechs.

Przytoczenie oświadczenia Żyda Abrahama Jacob ze Złotowa dotyczącego wyznaczenia terminu zwrotu długu przez farbiarza Lüschnera.

\footnotetext{
27 Patrz przypis 26.
} 
1. Kopia, pap., bifolium, $182 \times 237 \mathrm{~mm}$; niem.

2. Stan dobry, ślady złożenia, karta nierówno przycięta; pieczęci brak; znak wodny: orzeł pruski w koronie z berłem i mieczem w szponach, ze stylizowanym inicjałem „R” na piersi - nierozpoznany.

3. [C] Copia Document: Insinuat: [gl]; An den Färber: Simon Lüschner gegenwärtig zu Thoren [dl]; [D] 483.

4. -

5. Kat. II, I-3322; s. $483+$ brak.

6. Königl[iche] Westpr[eußische] Stadt: Gerichte |Sisty; [luka] NRvTrotter.

Sąd miejski w Jastrowiu prosi magistrat toruński o okazanie farbiarzowi Lüschner - przebywającemu w Toruniu - załączonych dyspozycji związanych $\mathrm{z}$ rozpoczętym podczas jego nieobecności $\mathrm{w}$ Jastrowiu postępowaniem o ściągnięcie wierzytelności oraz o pisemne potwierdzenie okazania załączników.

1. Oryg., pap., bifolium, $197 \times 336+194 \times 336 \mathrm{~mm}$; niem.

2. Stan dobry, ślady złożenia, ubytki w laku pieczętnym; pieczęć zabezpieczająca - patrz list nr 11; znaki wodne: 1.k. stylizowana litera „M”, 2.k. korona królewska z krzyżem - patrz też list $\mathrm{nr} 10$ - oba nierozpoznane ${ }^{28}$.

3. [A] An Einen Wolllöblichen Magistrat zu Thoren; [B] Subsidiales der Jastrovisch Gerichte, c. Docum. inser. an der [?] Färber Lüschner.; lect [um] d[en] 30 May. 1787.; 8; 21 [przekreślone]; =20; /-; 4; 33/8 [dwa ostatnie dopiski wykonano czerwonym atramentem]; [D] 21/5 87; 3a [przekreślone]; 475 $\div 476 ; 493 \div 494$.

4. -

5. Kat. II, I-3322; s. $475+494$.

6. Königl[iche] Westpr[eußische] Stadt Gericht |Sechs; Sisty; [luka] NRvTrotter.

${ }^{28}$ Litera „M” była stosowana w papierni w Wąsoszu koło Złotowa oraz w którejś z papierni w Kwidzynie. Por. F. Pabich, Papiernie nadnoteckie, s. 292; E. Kędra, Z dziejów papierni w Kwidzynie, Przegląd Papierniczy, t. 407, nr 12, 1977, s. 475-476. 


\section{NR 15}

1789, 12 II Jastrowie

Jastrow den 12te Februar 1789

Sąd miejski w Jastrowiu zwraca się z prośbą do magistratu toruńskiego o doręczenie mieszkającemu tam Johannowi Christianowi Koerner dołączonej dyspozycji i o pisemne potwierdzenie tego faktu.

1. Oryginał, pap., bifolium, $197 \times 337+197 \times 337 \mathrm{~mm}$; niem.

2. Stan dobry, ślady złożenia; pieczęć zabezpieczająca - patrz list nr 11; znak wodny: 1.k. korona królewska z krzyżem - patrz list nr 10, 2.k. brak nierozpoznany.

3. [A] An Einen Hochedeln Magistratzu Thorn; [B] Arm Supp[...-?]; Subsid[ium] des Stadt Gerichts zu Jastrow, c. doc. ins. an den [...] Joh. Christ. Körner.; lect[um] d[en] 20 Febr[uar] 1789;; 15; 6; 3; 2 [lub Z]; [D] 12 / 2 89; 3a

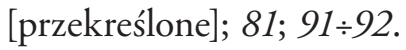

4. -

5. Kat. II, I-3324; s. $81+92$.

6. Königl[iche] Westpreuss[ische] StadtGericht|Sechs; Sisty; [luka] NRvTrotter.

\section{NR 16}

1799, 25 VI Krajenka

Krojanke den 25te Juny 1799

Cech młynarzy w Krajence potwierdza tytuł mistrza posiadany przez młynarza Paula Davida Banzemer, nadany mu na mocy patentu królewskiego 27 czerwca 1797 r.

1. Oryginał, pap., bifolium, $360 \times 211 \mathrm{~mm}$; niem.

2. Stan dobry, ubytki w pieczęci lakowej; 2 stemple drukowane, okrągłe, śr. 30 mm: opłaty „SECHS G[OLDEN] GROSCHEN” i z inicjałem „F”; pieczęć cechowa - lakowa, czerwona, okrągła, śr. $37 \mathrm{~mm}$, na obwodzie napis „DER · MULLER · G · WSIEGEL · ZU • [KROJANKE - ?] · 1788 [?]”; znaki wodne: 1.k. pruski orzeł w koronie z jabłkiem i berłem w szponach z inicjałami „FW” na piersi, 2.k. litery „DWK” - oba nierozpoznane. 
3. [C] a 33 [1. str. g i ld, oba podkreślone niebieską kredką]; [D] 6080c; Meisterbrief des Paul Dawid Banzemer (Müller) Krojanke 25. 6. 99. [ołówek].

4. -

5. Kat. III, 6080c.

6. Consili[um] Dirig[ens]: qua atsleh [atshles - ?] Pluwes [?]; P: Schultz Gewerck Alterkwen [-kuam - ?].

\section{NR 17}

1697 [1695?], 1 II Łobżenica Datum Lobzenis in Residentia protuni Cont u bern i nostri die prima Mensis Februarii proxima Anno D[omi]ni Millesimo Sexcentesimo 9imo S[ep]t[im]o [? - raczej 5to]

Cechmistrz i starsi cechu garncarzy w Lobżenicy w Wielkopolsce w województwie kaliskim zaświadczają, że Georg Rozewicz [Różewicz], mieszkający w mieście Kamień (Camen) - własności kardynała [Michała Stefana] Radziejowskiego ${ }^{29}$, arcybiskupa gnieźnieńskiego, wyuczył się rzemiosła u mistrza Michaela Siekierki i ma prawo używać tytułu mistrza.

1. Oryginał, pap., bifolium, $199 \times 125 \mathrm{~mm}$; łac.

2. Stan dość dobry, złożony, przetarcia na zgięciach; pieczęci przywieszonej brak; znak wodny - na ozdobnej tarczy wzór w kształcie odwróconej cyfry 8 - nierozpoznany.

3. [B] Liters Friennckis exerciptii nec non Manunissionis liber takonisy et ? Figulorum Civitatis Lobsens pro parte Honesti Georgy Rozewicz de [...]nuii [...] exidits [...] A.d. 1695; [D] 4803; Zechebrief das Tupferychellen [...] Georg Różewicz Lobsens. Februar 1697.

4. -

5. Kat. III, 4803.

6. Marii [?] Przedbramski, Cechmistrz; Wawrzyniec Weydowicz, Collega iego; Balcer Babiński, Brat stołowy; Antoni Dudkawicz; Barttomi Bielański; Szymon Molbert, pisarz Cechu tego.

29 K. R. Prokop, Polscy kardynatowie, Kraków 2001, s. 145-156. 
NR 18

1717, 6 VIII Łobżenica

So geschehen in Lobsentz, den 6. Augusti, nach der heilwörtigen Gebuhrt unsers Seligmachers, das Ein Tausend, sieben Hundert und Siebenzehenden Jahres

Burmistrz i rajcy miasta Lobżenica w Wielkopolsce wydają na prośbę Melchiora Lachmanna - pastora ewangelickiego w Batorowie (Batorae), świadectwo dobrego urodzenia dla jego przyjaciela Theodorusa Willeniusa, syna Johanna Willeniusa - pastora ewangelickiego w Radziczu (Radsitz) i Anny Marii Hahnin, co potwierdzili świadkowie - mieszczanie i kupcy: Samuel Schendel i Johann [Gottlob] Kortmann. Dziadkami T. Willenius ze strony ojca byli: Martinus Willenius - pastor ewangelicki w Grudziądzu i Regina Heinin, a ze strony matki Mathaus Hahn - pastor w (Cotlen) i (Shlen) [miejscowości nierozpoznane] i Anna Maria Bussin.

1. Oryginał, perg., $440 \times 411 \mathrm{~mm}$; niem.

2. Stan dobry, ślady zgięć i po szpilkach; pieczęci przywieszonej brak.

3. [D] 6361 [1. str., ld, wpisane ołówkiem]; Theodorius Wilenius. Lobsentz.

4. -

5. Kat. III, 6361.

6. Johann Grützmacher, Consill[ium] dirig[ens].

NR 19

1720, 26 I Łobżenica

(...) geschehen und gegeben in Lobsentz, den 26ten Tag Monaths January Im Jahr nach Christi Gebührt: Ein Tausend Sieben Hundert und Zwantzig

Burmistrz i rada miasta Łobżenica wydają na prośbę Johanna Gottloba Cortmann i Samuela Schendel, mieszczan i kupców, świadectwo dobrego urodzenia dla Johanna Fenger - kupca, syna Johanna Fenger - byłego burmistrza Łobżenicy i Cathariny Jandickin - córki byłego sędziego w Łobżenicy, Petera Jandicken.

1. Oryginał, perg., $487 \times 354+28 \mathrm{~mm}$; niem.

2. Stan dobry, brunatne przebarwienia, otwory po szpilkach; przywieszona pieczęć: plica, tasiemka niebiesko-żółta, pieczęć okrągła, woskowa, czar- 
na w drewnianej puszce, śr. $45 \mathrm{~mm}$, wizerunek dzika - odyńca na łące, na obwodzie tekst „SIGILLVM PROCONSVLARE CIVITATIS LOBZENENSIS AD 1617”. Zob. HMW, B-376, s. 376.

3. [B] Gebuhrts=Brieff Johann Fengers eines Kaufmans von Lobens bürtig. illat[um] d[en] 22 Martii 1720; [D] 5117; Lobsens Januar 1720 das Johann Fenger.

4. -

5. Kat. III, 5117.

6. Maciey Sokotowski, Notarius.

NR 20

1720, ? XII Łobżenica

Geschehen und gegeben in Lobsentz den Tag Decemb[e]r: der im Jahr nach Christi GebuhrtEin Tausend Siebenhundert und Zwantzig

Burmistrz i rada miasta Łobżenica wydają na prośbę Michaela Lindebein - wiceburmistrza i Samuela Hrabowskiego - (vice Kuhtes [?]), świadectwo dobrego urodzenia dla Johanna Cholevius - krawca, syna Michaela Cholevius - byłego członka rady i Anny Magdaleny Eveitschin.

1. Oryginał, perg., $454 \times 315+28 \mathrm{~mm}$; niem.

2. Stan dobry, pieczęci przywieszonej brak.

3. [B] Gebuhrts=brieff Johan Cholevii, eines Gewand Schneiders von Lobsenz gebürtig. illat [um] d[en] 20 Dec[ember] 1720; [D] 5143; Dec[em]b[e]r 1720. Johann Cholevius, Gewand=Schneider Lobsentz.

4. -

5. Kat. III, 5143.

6. Martinus Gritzmesser, Pro Consul Lobs[ener].

NR 21

1729, 27 VII Łobżenica

So geshehen Lobsentz den 27 July 1729

Burmistrz i rajcy miasta Łobżenica w starostwie nakielskim wydają na prośbę Griegera Bellach, bakałarza ze szlacheckiej wsi Dębionek (Dembionke), 
świadectwo dobrego urodzenia dla jego syna Johanna Gottlieba Bellach - ochrzczonego 26 lipca 1711 r. - co potwierdzili świadkowie, mieszczanie: Andreas Fiebich [?] - tkacz i Christoph Höllendeund(en) - szewc. Rodzicami J.G. Bellach są: wymieniony Grieger Bellach i Anna Maria Gecherin; dziadkami ze strony ojca byli: Jacob Bellach - słodownik z Debrzna (Preussischen Friedland) i Dorothea Shenudin, a ze strony matki Dawied Gecher - szkutnik z Gotlandii i Elisabeth Ewerin z Pomorza Szwedzkiego (Shwedshpommern).

1. Oryginał, perg., $464 \times 367 \mathrm{~mm}$; niem.

2. Stan dobry, przebarwienia; pieczęci przywieszonej brak.

3. [D] $6365 ; 52$.

4. -

5. Kat. III, 6365.

6. Martin Lubno, PL [President/Proconsul Lobsener?].

NR 22

1732, 29 IV Łobżenica

Lobsens den 29ten April. 1732\%

Starsi gminy protestanckiej w Łobżenicy ponownie proszą magistrat toruński o pomoc finansową i organizację zbiórki publicznej na rzecz tejże zadłużonej gminy.

1. Oryginał, pap., bifolium, $2 \times 167 \times 199 \mathrm{~mm}$; niem.

2. Stan dobry, ślady złożenia, na środku plama po zalaniu; pieczęci i znaków wodnych brak.

3. [D] $323 \div 326 ; 164 \div 165$ [niebieski długopis]; 24 / 4 32; 5 [oba dopiski niebieska kredka].

4. -

5. Kat. II, I-3340; s. 323-326.

6. Johann George Könilzer; Johann Kortman mpp; Samuel Schendel / Kirchen Seniores. 


\section{NR 23}

\section{3, 13 III Toruń}

Thorn d[en] 13: Mertz 1743

Deputowani z Łobżenicy wysłani do Torunia zwracają się z prośbą do magistratu toruńskiego o pomoc finansową dla łobżenickiej „ewangelickiej luterańskiej gminy” z powodu jej ciężkiej sytuacji materialnej.

1. Oryginał, pap., bifolium, $2 \times 226 \times 367 \mathrm{~mm}$; niem.

2. Stan dobry, ślady złożenia; pieczęci brak; znaki wodne: 1.k. inicjał „IV”, 2.k. „Horn” - pod nim znak „IV” - oba nierozpoznane ${ }^{30}$.

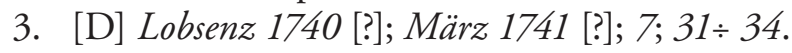

4. -

5. Kat. II, I-3410; s. 31-34.

6. Johann Gottlob Kortman mpp; Johann Tobias Pietius mpp.

NR 24

1749, 8 V Łobżenica

Datum Lobzenica, die 8. Maj. anno 1749

Burmistrz i rajcy miasta Łobżenica w Wielkopolsce wydają Davidowi Pannenberg - piekarzowi narodowości niemieckiej; synowi Georga Pannenberg - mieszczanina, piekarza i Cathariny Geering - świadectwo dobrego urodzenia, co potwierdzili: David Rohenau - mieszczanin, piekarz i rajca oraz Martin Mannthej - mieszczanin i piekarz.

1. Oryginał, pap., bifolium, $381 \times 233 \mathrm{~mm}$; niem.

2. Stan dość dobry, przedarcia na zgięciach; pieczęć papierowo-lakowa, czerwona, między kartami bifolium, okrągła, śr. 34 mm, wizerunek jak na

30 Inicjał „IV” stosował francuski papiernik działający na rynku holenderskim Jean Villedary (oraz jego syn - również Jean). Por. С. А. Клепиков, dz. cyt., s. 79, fil. 977; G. Piccard, Findbuch VII. Wasserzeichen Horn, Stuttgart 1979, tablica IX, fil. 223; E. Ruffle, Watermarks - a hidden history [on-line]. [Dostęp 12 grudnia 2010 r.]. Dostępny w World Wide Web: http://www.nhm.ac.uk/research-curation/departments/botany/ news-events/newsletter/archive/issue5/research/index.html. 
pieczęci przy liście nr 19; znak wodny: 1.k. „Horn”, 2.k. inicjał „IV” - oba nierozpoznane ${ }^{31}$.

3. [B] David Pannenberg Geburths-Brief eines Boßv. ? Bekers. lect [um] d[en] 23 April 1751; [D] 5626; Lobsens Mai 1749; 56261 [1.str. ld, niebieski długopis].

4. -

5. Kat. III, 5626/1.

6. Michael Lindebein, Procon[sul] Lobsener; Antonius Jacobus Gręczkiewicz, Notarius Utrius[que] Officii Lobsen[sis].

\section{NR 25}

1749, 8 V Łobżenica

Datum w Łobżenicy Die 8va Mensis May Anno Domini Millesimo Septingentesimo Quadragesimo Nono

Burmistrz i rada miasta Łobżenica zaświadczają, że Dawid Pannenberg został mieszczaninem w tym mieście 25 lutego $1744 \mathrm{r}$. i przez cały okres zamieszkiwania dobrze się sprawował.

1. Oryginał, pap., bifolium, $333 \times 197 \mathrm{~mm}$; pol.

2. Stan dobry, brzegi postrzępione; pieczęć papierowo-lakowa, czerwona, między kartami bifolium, okrągła, śr. $34 \mathrm{~mm}$, wizerunek jak na pieczęci przy liście nr 19; znaki wodne: 1.k. „Madonna”, 2.k. - z powodu opieczętowania nieodczytany - nierozpoznane.

3. [D] 56262 [1.str. ld, długopis].

4. -

5. Kat. III, 5626/2.

6. Michael Lindebein, Procon[sul] Lobsener; Antonius Jacobus Gręczkiewicz, Notarius Utrius[que] Officy Lobsen[sis].

31 Patrz przypis do listu nr 23. 


\section{NR 26}

1754, 1 VII Łobżenica

Gegeben in Lobsentz d[en] 1-ste July An[n]o 1754

Burmistrz, rada i sąd miasta Łobżenica w Wielkopolsce wydają majstrowi Samuelowi Jeschke - mieszczaninowi i rzeźnikowi; przez 5 lat i 1 miesiąc mistrzowi cechu, mężowi i ojcu: Jacobusa, urodzonego 3 sierpnia $1751 \mathrm{r}$. (chrzestni: Michael Lindebein i Steffan Mirucki) i Cathariny, urodzonej 4 listopada 1753 r. (chrzestni: Peter Schultz i Johan Gering - wszyscy mieszczanie z Łobżenicy) - zaświadczenie, iż sprawował się należycie i wypełniał swe powinności.

1. Oryginal, pap., bifolium, $341 \times 204 \mathrm{~mm}$; niem.

2. Stan dość dobry, brzegi postrzępione, przetarcia na zgięciach; pieczęć papierowo-lakowa, lak między kartami bifolium, okrągła, śr. $34 \mathrm{~mm}$, wizerunek jak na pieczęci przy liście nr 19; znaki wodne: 1.k. „ryba” w stylizowanym otoku zwieńczonym koroną, 2.k. inicjały „ICM” - patrz list nr 12 - oba nierozpoznane ${ }^{32}$.

3. [D] 5722; 1. Juli 1754? Zeugniss für den Fleischmeist[er] Samuel Jeschke Lobsentz.

4. -

5. Kat. III, 5722.

6. Michael Schultz, President Lobsensis.

\section{NR 27}

\section{5, 15 VIII Łobżenica}

Członkowie gminy ewangelickiej z Kobżenicy proszą magistrat toruński o pomoc w jej utrzymaniu, motywując swą prośbę ciężką sytuacją związaną między innymi z trwającym od 21 lat procesem sądowym.

1. Oryginat, pap., bifolium, $235 \times 383+231 \times 383 \mathrm{~mm}$; niem.

2. Stan dobry, ślady złożenia; pieczęci brak; znaki wodne: 1.k. inicjały „HR”, 2.k. „Horn”, poniżej inicjały „CR” - oba nierozpoznane. 
3. [D] 1765 [ołówek]; Lobsenz August 1765; 7; $114 \div 115 ; 146 \div 147$.

4. -

5. Kat. II, I-3421; s. $114+147$.

6. Peter Gottlob Pilasky Past[or] L[obsener]; „Martin Karkoschke mpp; Johann Tobias Pietius mpp; Gottlob Zimdler[...] | Eltesten und [..]rste hern der Ewagel[ischen] Gemeine.

\section{NR 28}

Rada miasta Łobżenicy, w odpowiedzi na pismo z Torunia z dnia 13 lutego 1767 r., oświadcza, że nieznana jest kobieta o podanym tam imieniu i nazwisku mająca być żoną młynarza kaszy - jednocześnie deklaruje gotowość do dalszych poszukiwań.

1. Oryginał, pap., bifolium, $239 \times 376+224 \times 376 \mathrm{~mm}$; niem .

2. Stan dość dobry, prawa i górna krawędź poszarpane, ślady złożenia, przedarcia na zgięciach; pieczęć zabezpieczająca papierowo-lakowa, brunatna, okrągła, śr. ok. $32 \mathrm{~mm}$, wizerunek herbu miasta - biegnący dzik, niedokładnie odciśnięta, napis na otoku nieczytelny ${ }^{33}$; znaki wodne: 1.k. „Horn”, poniżej napis: „D\&C BLAUW”, 2.k. napis „D\&C BLAUW”.

3. [A] III Nobilibus ac Spectalibus Dominis ProConsuli et Consulibus SaReMattis [?] Civitatis Thorunensis Dominis Honoratis ac Estimatissimis Thoronii; [B] Litt[era] Des Magistr[at] von Lobsenz des Grüz Müllers Frau betreffend.; Lect[um] d[en] 24 Febr[uar] 1767\%; 3-; 6; 19 [?]; 20 / 2. 67; 5; [D] 217-220.

4. -

5. Kat. II, I-3343; s. 217-220.

6. PraeConsules et Consules Civitatis Lobzynensis.

33 Podobną wymiarami pieczęć z legendą SIGILLVM ADVOCATIALE CIVITATIS LOBZENENSIS 1671 odnotowuje M. Gumowski, Pieczęcie i herby miast wielkopolskich, Poznań 1932 (dalej: PiHMWlkp.), s. 173. 
NR 29

1767, 14 X Łobżenica

Lobsenia d[ie] 14 bris 1767

[Joseph von] Radoliński składa podziękowania radzie miasta Torunia za starania w sprawie odzyskanych na mocy wyroku sądowego jego pieniędzy, które był mu dłużny przełożony synagogi łobżenickiej.

1. Oryginał, pap., bifolium, $179 \times 216+178 \times 216 \mathrm{~mm}$; łac.

2. Stan dobry, ślady złożenia; pieczęć prywatna [?], papierowo-lakowa, czerwona, owalna, $20 \times 23 \mathrm{~mm}$, wizerunek herbu Leszczyc z żurawiem [orłem?] jako trzymaczem; znak wodny: „Horn” - nierozpoznany.

3. [D] $16 ; 349 \div 350 ; 359 \div 360$.

4. -

5. Kat. II, I-3513; s. $349+360$.

6. Singularem amicum ac Levum[.?] LiCantsracpk [?] Radolinski mpp.

\section{NR 30}

1768, 5 VII Łobżenica

Lobsentz d[en] 5 Jul[i] 1768

Członkowie gminy ewangelickiej i burmistrz Łobżenicy proszą magistrat toruński o udzielenie wsparcia ich gminie po pożarze, który w nocy 6 maja 1768 r. strawił m.in. zbór - a łącznie 15 budynków w mieście.

1. Oryginał, pap., bifolium, $2 \times 196 \times 316 \mathrm{~mm}$; niem.

2. Stan dobry, ślady złożenia, ubytki i pęknięcia pieczęci; pieczęć papierowo-lakowa, czerwona, okrągła, śr. ok. $32 \mathrm{~mm}$, wizerunek z herbem miasta, nad biegnącym dzikiem umieszczona data roczna 1748 , na obwodzie napis „SIGILLUM • ADVOC[...]ATE [?] · C[I]VITAT • L[O]B[SE]NENSIS”, patrz pieczęć i przypis w liście nr 28; znaki wodne: 1.k. „Pro Patria”, 2.k. stylizowany inicjał „R” - oba nierozpoznane.

3. [D] Lobsenz 5 Juli 68.; 5.; $439 \div 442$.

4. -

5. Kat. II, I-3343; s. 439-442.

6. Seniores und Vorstehere des Evang[elische] Gemeinde zu Lobsentz. und Burgermeister. 


\section{NR 31}

1771, 21 I Łobżenica

Lobsentz d[en] 21ten Januarius 1771\%

Burmistrz i rada miasta Łobżenicy proszą magistrat toruński o odpis akt zatrzymania Agaty Milcken [Miecken?] oskarżonej o cudzołóstwo z Gottlobem Zincke [lub Zineke] - mieszczaninem łobżenickim i o zabójstwo poczętego dziecka.

1. Oryginał, pap., bifolium, $201 \times 320+197 \times 320 \mathrm{~mm}$; niem.

2. Stan dobry, ślady złożenia; pieczęcie: 1 . zabezpieczająca, 2. pod pismem - obie jednakowe, niedokładnie odciśnięte, ubytki - lakowe, czerwone, okrągłe, śr. ok. $32 \mathrm{~mm}$, na obwodzie napis ,[...]ZENENSIS · A.D · 16[.]7 [...] CIVIT[...]”34; znaki wodne: 1.k. „Pro Patria” z inicjałami „GSB” na prawo od głowy kobiety, 2.k. korona królewska z inicjałami „GR” pod spodem - oba nierozpoznane.

3. [A] An Wohledlen Hochgestrengen und Hochwohlweisen Magistrat zu Thorn; [B] Subsid[ium] der EE. von Lobsenz eine gewisse Person welche eines Kind ermord[et] bezuchtiget [...] betest.; lect[um] d[en] 2 Febr[uar] 1771.; [D] 21 / 1 71.; 5; $315 \div 316 ; 343 \div 344$.

4. -

5. Kat. II, I-3344; s. $315+344$.

6. Burgermeister und Rath daselbst.

\section{NR 32}

1773, 2 X Łobżenica

Lobsens den 2te Octob[e]r 1773\%

Sąd w Łobżenicy zwraca się do magistratu toruńskiego w imieniu przedstawicieli łobżenickiej synagogi w sprawie egzekucji długu z tytułu podatku w wysokości 40 dukatów na rzecz tejże synagogi, od zapłacenia którego uchyla się przebywający obecnie w Toruniu Żyd Fabisch Hirsch.

1. Oryginał, pap., bifolium, $211 \times 353+210 \times 353 \mathrm{~mm}$; niem. s. 172 .

34 Być może jest to pieczęć wspomniana przez M. Gumowskiego w PiHMWlkp., 
2. Stan dobry, ślady złożenia; 2 stemple drukowane, pieczęć lakowa, czerwona, owalna, $25 \times 28 \mathrm{~mm}$, spękana, wizerunek pruskiego orła z jabłkiem i berłem w szponach, na obwodzie napis „KÖN[IGLICHE] PR[EUSSISCHE] VOGTEY GERICHT · ZU VANDSBURG [WIECCBORK]"; znaki wodne: 1.k. „O W | LA [obie litery odwrócone o 180 stopni] SSEKODEK", 2.k. orzeł pruski z jabłkiem i berłem w szponach, poniżej napis „KPHSTvKC” pomiędzy „lilijkami” - oba nierozpoznane.

3. [A] Am Einen HochEdlen Magistrat zu Thoren. Iorexposhen [?]; [B] Subsidiat. Des K[önigliche] $\operatorname{Pr}[e u] \beta[$ [ische] Landwogtei Gerichts aus Lobsenz rat.[?] des Judens Hirsch. lect[um] d[en] 8 Octob[e]r. 1773; 13; /8; działanie w „słupku”: $16[+] 3[=] 19 ; 6$ [czerwony atrament]; [C] S[eine]r: Königl[ichen] Majestat von Preußen zum Land:Woigtey=Gericht Verorderte Director, Rath und Ashishor [1, pod treścią pisma]; An Einen Löbl[ichen]

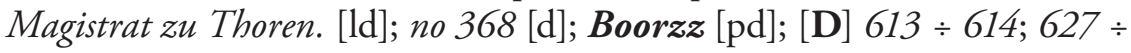
628; 2 / 10. 73; 3a [przekreślona].

4. -

5. Kat. II, I-3316; s. $613+628$.

6. J. Salomon; Burghof; [luka].

\section{NR 33}

1773, 10 XII Łobżenica

Lobsens den 10ten $\mathrm{D}$ [ecem]bris 1773

Sąd w Łobżenicy zwraca się do magistratu toruńskiego z prośbą o umieszczenie w miejscu publicznym załączonego obwieszczenia tak, by pozostawało tam co najmniej 8 dni przed terminem 15 kwietnia, po czym odesłać je z potwierdzeniem wywieszenia.

1. Oryginał, pap., bifolium, $211 \times 354+211 \times 351 \mathrm{~mm}$; niem.

2. Stan dobry, ślady złożenia; pieczęcie: patrz opis pieczęci w liście nr 32; znaki wodne: 1.k. orzeł pruski z berłem i jabłkiem w szponach, poniżej napis ,KPHSTvKC", 2.k. w trzech wierszach tekst „HASSEP | N M | N I" [podobieństwo do znaku z listu nr 9, 1. karta] - oba nierozpoznane.

3. [A] An Einen HochEdlen Magistrat in Thoren.; Franco; [B] Subsidiales E. K. Pr[eu]ß[ischen] Landvogtei-Gerichts aus Lobsens Edictal b[...] lect[um] $d[$ en] 14 Januar 1774.; 4 [dwukrotnie]; /8/; 13/4[..]; X; działanie w „słupku": $8[+] 6[=] 14 ; 20$ [bordowy atrament]; [C] S[eine]r. König[liche] Ma- 
jestaet von Preußen zum Landvogtey-Gericht allhier Verordnete Director, Rath und Asheshor [1, pod treścią pisma]; An Einen Hochedlen Magistrat in Thoren [ld]; no.738 [d]; Chappe [pd]; [D] 10.12.73. [niebieski ołówek]; $689 \div 690 ; 703 \div 704$.

4. -

5. Kat. II, I-3316; s. $689+704$.

6. J. Salomon; Burghof; [luka].

\section{NR 34}

1774, 29 IV Łobżenica

Lobsens den 29 April 1774

Sąd w Łobżenicy zawiadamia magistrat toruński o postępowaniu wobec wierzycieli zmarłego podkomorzego Francisci von der Goltz i prosi o publiczne ogłoszenie tego faktu.

1. Oryginał, pap., bifolium, $217 \times 361+214 \times 360 \mathrm{~mm}$; niem.

2. Stan dobry, ślady złożenia; pieczęcie: patrz opis pieczęci w liście nr 32, z tym że pieczęć pod pismem jest papierowo-lakowa; znaki wodne: 1.k. orzeł pruski z berłem i jabłkiem w szponach, poniżej napis „KPHSTvKC", 2.k. napis „HCW" - oba nierozpoznane.

3. [A] An Eure Löbl[ichen] Magistrat der Stadt Thorn; [B] Litt[era] E. K. $\operatorname{Pr}[$ eu]ß[ischen] Landvogteigerichts weg einer Edictal - Citation lect[um] d[en] 11 Maii 1774; f. Ostromescko; 17/; działanie w "słupku”: $10[+] 2[=] 12[+] 3[=] 15 ;[\mathbf{C}]$ In Königl[ichen] Majestaet von Preußen, zum Land:Woigtey:Gerichts, Verorderte Director, Rath und Ashishor [1, pod treścią pisma]; An Euren Löbl[ichen] Magistrat zu Thoren [ld]; No 302a\% [d]; Borzz [pd]; [D] 181; 230; 29/4 74.; 3a [przekreślona].

4. -

5. Kat. II, I-3317; s. $181+230$.

6. J. Salomon; Burghof; Guberlk[...]. 


\section{NR 35}

Sąd w Lobżenicy powiadamia magistrat toruński o postępowaniu spadkowym po zmarłym Jacobie von Garizynsky [?] i prosi o publiczne ogłoszenie tego faktu oraz jego pisemne potwierdzenie.

1. Oryginał, pap., bifolium, $101 \times 353 \mathrm{~mm}$; niem.

2. Stan dobry, ślady złożenia; 2 stemple drukowane; znak wodny: tylko 1. karta - podobieństwo do herbu Sępólna Krajeńskiego (postać św. Wawrzyńca), poniżej w stylizowanej obwódce litery „IHK“ - nierozpoznany.

3. [C] In Königl[iche] Majestaet von Preußen, zu der Land:Woigtey:Gerichts, Verorderte Director, Rath und Asheshor [1, pod treścią pisma]; An Einem Wohllobl[ichen] Magistrat zu Thoren [ld]; No 586. [d]; Borzz [pd]; [D] 1/6 74.; 197; $3 a$ [przekreślona].

4. -

5. Kat. II, I-3317; s. $197+$ brak.

6. J. Salomon; Burghof.

NR 36

1774, 29 VIII Lobżenica

Lobsens den 29te August 1774

Sąd w Łobżenicy prosi magistrat w Toruniu o powiadomienie mieszkającej tam wdowy von Glembocka (najpóźniej do 13 listopada) o postępowaniu wobec wierzycieli po zmarłym Jacobie von Garizynsky [?].

1. Oryginał, pap., bifolium, $211 \times 350 \mathrm{~mm}$; niem.

2. Stan dobry, ślady złożenia, przy prawym marginesie ubytek papieru; 2 stemple drukowane; znak wodny: tylko 1. karta - orzeł pruski z berłem i jabłkiem w szponach, poniżej napis „KPHSTvKC” między „lilijkami” - nierozpoznany.

3. [C] An Einem Wohl Löbl[ichen] Magistrat zu Thoren [ld]; No 1087al. [d]; Borzz [pd]; [D] 29/8 74.; 239; $3 a$ [przekreślona].

4. -

5. Kat. II, I-3317; s. $239+$ brak. 
6. Königl[iche] Preuß[ische] Land:Voigtey:Gerichts zu Lobsens |J. Salomon; [luka] Guberlk[...].

NR 37

1774, 1 IX Łobżenica

Lobsens den 1ten Sept[em]ber. 1774\%

Sąd w Łobżenicy prosi magistrat toruński w imieniu starszego łobżenickiej synagogi o znalezienie przebywającego obecnie w Toruniu Żyda Fabischa Hirsch, należącego do tej synagogi i uchylającego się od opłat na jej rzecz.

1. Oryginał, pap., bifolium, $214 \times 355 \mathrm{~mm}$; niem.

2. Stan dobry, ślady złożenia; 2 stemple drukowane; znak wodny: orzeł pruski z berłem i jabłkiem w szponach, z inicjałem „R” na piersi, poniżej napis ,KPHSTVKC" - nierozpoznany.

3. [C] An Einen Wohl Löbl[ichen] Magistrat zu Thoren [1, pod treścią pisma]; No. 23. [d]; Borzz [pd]; [D] 1/9 74.; 241 $242 ; 3 a$ [przekreślona].

4. -

5. Kat. II, I-3317; s. $241+$ brak.

6. Königl[iche] Preus[sische] Land:Voigtey:Gerichts zu Lobsens|J. Salomon; Burghof; Guberlk[...].

\section{NR 38}

1774, 30 X Łobżenica

Lobsens den 30te Octob[e]r: 1774

Sąd w Łobżenicy w odpowiedzi na pismo magistratu toruńskiego z 28 października 1774 r. w sprawie stawienia się na przesłuchanie starszego żydowskiego Salomona Gabriela, zawiadamia tenże magistrat o poinformowaniu tegoż Gabriela, że w ciągu tygodnia ma stawić się w Toruniu i zeznawać w sprawie aresztowanego inowrocławskiego Żyda Dawida Guldmana, przy czym gwarantuje się mu powrót po przesłuchaniu.

1. Oryginał, pap., bifolium, $198 \times 332 \mathrm{~mm}$; niem.

2. Stan dobry, ślady złożenia; pieczęci brak; znak wodny: „kwiat w wazonie”, pod nim litery „MLI” - nierozpoznany. 
3. [C] An d[en] Wohllöbl[ichen] Magistrat zu Thoren [1, pod treścią pisma]; ex officio [ld]; No 463 [d]; Borzz [pd]; [D] 3/10 74; 251; 3a [przekreślona].

4. -

5. Kat. II, I-3317; s. $251+$ brak.

6. Königl[iche] Preuß[ische] Land:Voigtey Gericht J. Salomon; Burghof; Guberlk[...].

\section{NR 39}

Sąd w Kobżenicy zawiadamia magistrat toruński w związku ze sprawą Żydów: Salomona Gabriela z Kobżenicy i Abrahama Hirsch z Inowrocławia (Inowratzlaw), że uczynił wszystko, co mógł, do 30 października $1774 \mathrm{r}$. [patrz list nr 38], a dalsze działania są uzależnione od dostarczenia informacji o żądaniach miejskich (? - Ortsanforderte).

1. Oryginał, pap., bifolium, $207 \times 352 \mathrm{~mm}$; niem.

2. Stan dość dobry, ślady złożenia i zalania, drobne uszkodzenia biologiczne; 2 stemple drukowane; znak wodny: być może ozdobny inicjał - nierozpoznany.

3. [C] An Einen Löbl[ichen] Magistrat zu Thoren [1, pod treścią pisma]; No. 25. [d]; Borzz [pd]; [D] 27/11 74; 285 286; 3a [przekreślona].

4. -

5. Kat. II, I-3317; s. $285+$ brak.

6. Königl[iche] Preuß[ische] Land:Voigtey Gericht|J. Salomon; Burghof; Guberlk[...].

NR 40

Sąd w Łobżenicy informuje magistrat toruński w sprawie stawienia się na przesłuchanie w Toruniu (w sprawie Dawida Guldmanna) starszego żydowskiego Salomona Gabriela (pisma z Torunia z 17 października i 18 listopada i odpowiedzi z Łobżenicy z 30 października i 27 listopada 1774 r.), iż jest to 
niemożliwe (mimo wystawienia pisemnego mandatu wzywającego go do stawienia się w Toruniu w ciągu 4 tygodni), ponieważ ten 20 grudnia stawił się przed sądem i oznajmił, że złożył zeznania do protokołu w wyżej wspomnianej sprawie przed urzędnikiem urzędu justycjariusza Grunenthalem [w dobrach Radolińskiego?] i od tej pory nie może być pociągany do składania zeznań w tej sprawie, tym bardziej poza granicami [państwa] ${ }^{35}$.

1. Oryginał, pap., bifolium, $209 \times 352 \mathrm{~mm}$; niem.

2. Stan dobry, ślady złożenia; 2 stemple drukowane; znak wodny: pruski orzeł w koronie z berłem i jabłkiem w szponach, kadłub pokryty „łuskami" - nierozpoznany.

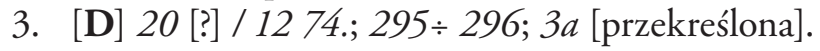

4. -

5. Kat. II, I-3317; s. $295+$ brak.

6. dienst willige König[liche] Preuß[ische] Land-Woigten Gericht|J. Salomon; Burghof; Guberlk[...].

\section{NR 41}

List sądu w Łobżenicy do magistratu toruńskiego w sprawie egzekucji wierzytelności i uregulowania dodatkowych opłat od Żyda inowrocławskiego - Abrahama Hirsch.

1. Oryginat, pap., bifolium, $204 \times 339+201 \times 338 \mathrm{~mm}$; niem .

2. Stan dobry, ślady złożenia; 2 stemple drukowane, pieczęć sądowa lakowa, czerwona, popękana - tożsama z pieczęcią w liście nr 32; znaki wodne: na obu kartach pruski orzeł w koronie $\mathrm{z}$ berłem i jabłkiem w szponach, poniżej napisy: 1.k. „KREISvKC”, 2.k. „H[.]ASSERODER+” - oba nierozpoznane.

3. [A] An Wobllöblichen Magistrat zu Thoren; [B] Litt[era] [..] Königl[ichen] Pr[eußischen] Landvogteigerichts aus Lobsenz am des Juden Hirsch| lect [um] d[en] 8 Marty 1775; 15; 12/15; [D] 19/2 75.; $311 \div 312$; $353 \div 354 ; 3 ; 158$ [dwa ostatnie przekreślone].

4. -

35 Toruń znalazł się w granicach Prus dopiero po drugim rozbiorze Polski w 1793 r. 
5. Kat. II, I-3311; s. $311+354$.

6. Königl[iche] Preuß[ische] LandWoigtey Gericht |J. Salomon; Burghof; Guberlk[...].

\section{NR 42}

Landrat Billerbeck prosi magistrat toruński o rozpatrzenie sprawy swojego kamerdynera Jacoba Eggert przeciwko Heinrichowi Schiemann - rolnikowi (Einsaensen) z Czarnowa (wieś pod jurysdykcją toruńską) o zwrot 100 guldenów pruskich i załącza kopię weksla.

1. Oryginał, pap., bifolium, $207 \times 350+168 \times 350 \mathrm{~mm}$; niem.

2. Stan dobry, ślady złożenia; 2 stemple drukowane - opłata „EIN G.GROSCHEN”; znak wodny: 1.k. pruski orzeł w koronie z berłem i jabłkiem w szponach, 2.k. inicjały „CT” - oba nierozpoznane.

3. [D] $14 / 2.82 ; 9 \div 11 ; 3 a$ [przekreślona].

4. -

5. Kat. II, I-3321; s. $9+12$.

6. CvBillerbeck $\mid$ Königl[iche] Preuß[ische] Landrath Camminschen Kreyßes im Netz District und Director daran Fortifications Geschiefts zu Graudentz.

Kopia umowy zawartej w Pałczu koło Bydgoszczy (Palsch) w dniu 15 stycznia 1775 r., na mocy której Jacob Eggert pożycza Heinrichowi Schiemann 100 guldenów pruskich (oprocentowane na 6,1\% w skali roku) do 1 maja $1775 \mathrm{r}$.

1. Oryginal, pap., bifolium, $197 \times 330+195 \times 335 \mathrm{~mm}$; niem.

2. Stan dobry, ślady złożenia; pieczęci brak; znaki wodne: 1.k. „goździk”, pod nim w stylizowanej obwódce litery „ICM”, 2.k. „Madonna w mandroli" - oba nierozpoznane. 
3. [C] S: Kopia 4 ppd [? - lg]; \# [g]; Vorstehende Abschrift stimmet von Wort zu Wort mit der Original-Obligation. Lobsens. den 14 te Februar $1782 \mid \mathrm{Cv}$ Billerbeck; 13.

4. -

5. Kat. II, I-3321; s. $13+40$.

6. CvBillerbeck.

Oświadczenie Jacoba Eggerta, kamerdynera landrata Billerbecka, o przedłużeniu terminu spłaty długu 100 guldenów pruskich z odsetkami, który ma u niego Heinrich Schiemann z Czarnowa, do święta St. Michealis [29 IX] 1782 r., oraz że po zwrocie całej kwoty do Billerbecka zostanie odesłany weksel dłużny.

1. Oryginał, pap., bifolium, $2 \times 195 \times 333 \mathrm{~mm}$; niem.

2. Stan dobry, ślady złożenia; pieczęć lakowa, czerwona, okrągła, śr. ok. $28 \mathrm{~mm}$, popękana, ubytki, wizerunek - bróg z herbu Leszczyc na tarczy podtrzymywanej przez dwa a nioły, na obwodzie napis: „LOBSENTZSCH · V · RADOLINSKISCHES · PATRIM:GERICHTS:SIEGEL .”; znaki wodne: 1.k. pruski orzeł w koronie z berłem i jabłkiem w szponach, poniżej napis „FLATOW”, 2.k. litery „ICM” - patrz list nr 12 - napis pod orłem wskazuje na papiernię w Złotowie ${ }^{36}$.

3. [D] $125 ; 127$.

4. -

5. Kat. II, I-3321; s. 125-127.

6. ? Krause; Kromeu [?]. 


\section{NR 45}

1782, 13 VII Łobżenica

Lobsens den 13-ten July 1782

Landrat Billerbeck zawiadamia magistrat toruński, że po jego decyzji [?] Eggert postanowił przedłużyć okres spłaty długu do święta St. Michaelis [29 IX] 1782 r., i prosi jednocześnie, by magistrat wpłynął na Schiemanna, by ten jak najszybciej oddał należność, po czym natychmiast otrzyma swój kwit dłużny - dołącza też oświadczenie Eggerta [patrz list nr 44].

1. Oryginał, pap., bifolium, $2 \times 198 \times 337 \mathrm{~mm}$; niem.

2. Stan dobry, ślady złożenia; pieczęci brak; znaki wodne: „orzeł pruski” i litery „ICM” - identyczne jak w liście nr 44 - papiernia w Złotowie ${ }^{37}$.

3. [D] 13 Juli 1782; 123; 129; 3 a.

4. -

5. Kat. II, I-3321; s. $123+130$.

6. CvBillerbeck|Königl[iche] Preuß[ische] Landrath des Cammin und Nakelschen Kreisses.

NR 46

1784, 22 XI Łobżenica

zu Lobsens den 22-e Nov[em]b[e]r1784

Sąd w Łobżenicy zwraca się do rady miasta Torunia w sprawie wdowy Roggin - mieszkającej w okolicach Łobżenicy - aby w wypadku zgłoszenia się krawca Barcharda załatwić sprawę bez toku urzędowego.

1. Oryginat, pap., bifolium, $198 \times 335+198 \times 334 \mathrm{~mm}$; niem.

2. Stan dobry, ślady złożenia; pieczęci brak; znaki wodne: 1.k. „ryba” z herbem Elbląga - patrz list nr 11, 2.k. litery „ICM” - patrz list nr 12 - oba nierozpoznane ${ }^{38}$.

3. [C] $N r 105$ [d]; [D] 22 / 11. 84; 99; 121; 52; 3 [dwa ostatnie przekreślone].

4. -

37 Tamże.

38 Tamże. 
5. Kat. II, I-3313; s. $99+121$.

6. Krause [?]; Staten [?].

\section{NR 47}

1791, 1 VI Toruń

Caspar Levin, Żyd i kupiec z Łobżenicy (handlujący używaną odzieżą), skarży się radzie miasta Torunia na, niesłuszne jego zdaniem, represje, które spotkały go ze strony przewodniczącego urzędu wetowego [Wett-Praeses; wówczas był nim Gotfried Giller], i prosi o wyjaśnienie całej sprawy.

1. Oryginat, pap., bifolium, $205 \times 329+178 \times 329 \mathrm{~mm}$; niem.

2. Stan dobry, ślady złożenia; pieczęci brak; znaki wodne: 1.k. „Pro Patria”, 2.k. wewnątrz okręgu korona, poniżej litery „GR” w stylizowanym wień$\mathrm{cu}$ - oba nierozpoznane.

3. [B] Supplique des Jude Caspar Levi.; lect[um] d[en] 1. Junii 1791; [D] Juni 91.; $183 \div 186 ; 7$.

4. -

5. Kat. II, I-3441; s. 183-186.

6. Caspar Levin aus Lobsens.

\section{NR 48}

1792, 17 VII Toruń

Thorn d[en] 17 Julii 1792

Casper [!] Levin, Żyd z Łobżenicy, prosi magistrat toruński o pozwolenie na zamieszkanie jego żony i dzieci w mieście do jarmarku w święto apostołów Szymona i Judy (Simon Judae Markt) [święto przypada na 28 października], a jemu samemu na swobodne jego opuszczanie tak, by z dochodów mógł stopniowo zaspokoić roszczenia swoich wierzycieli.

1. Oryginał, pap., bifolium, $195 \times 334+196 \times 334 \mathrm{~mm}$; niem.

2. Stan dobry, ślady złożenia; pieczęci brak; znaki wodne: tylko 2.k. pruski orzeł w koronie z berłem i mieczem w szponach - nierozpoznany.

3. [B] Supplique des Juden Caspar Levin aus Lobsens; lect[um] d[en] 18. Jul[i] 1792.; [D] Juli 92.; $359 \div 360$; $369 \div 370$; 7 . 
4. -

5. Kat. II, I-3442; s. $359+370$.

6. Casper Lewin aus Lobsenz.

NR 49

1402, 4 VII Mirosławiec

(...) Fredland, (...) Anno 1402. Am 8ten Tage nach Lichtumh

Burmistrz i rajcy Mirosławca polecają radzie miasta Torunia Conrada Rudulffa.

1. Oryginał, pap., $200 \times 164 \mathrm{~mm}$; niem.

2. Stan zły, złożony jako list; pieczęć oderwana wraz z częścią karty i tekstu; wg odbicia na innych fragmentach karty pieczęć była okrągła, śr. ok. $50 \mathrm{~mm}$, wizerunek bramy miejskiej z dwoma basztami [?]. Zob. HMW, B-410, s. 382 - odmiana? ${ }^{39}$

3. [A] Den vil Erben v[...] Mannen, BurgerM[...] hirn tzu Thor[...] uns[er]n libl[iche]n ge[...]; Anno 1402. Am 8ten Tage nach Lichtumh.

4. -

5. Kat. III, 4531.

6. Burgermeysst[er] unde Rathmanne tzu Fredland.

NR 50

1727, 4 I Mirosławiec

So geshen Neu Friedland in Groß Pohlen d[en] $4 \mathrm{Ja}$ nuarii Anno Ein Tausent Sieben Hundert und Siebenen Zwantzi

Burmistrz i rajcy miasta Mirosławiec w Wielkopolsce wydają Christianowi Kersten [krawiec]; synowi Christiana Kersten - cieśli i mieszczanina i Dorotei Carsburgin; świadectwo dobrego urodzenia, co potwierdzili świadkowie: Johan Mattey - mieszczanin i asesor sądowy, Johan Jeorgi - mieszczanin, kupiec i asesor sądowy, mistrz Walentin Könne - mieszczanin i krawiec.

39 Być może to o tej pieczęci wspomina M. Gumowski w PiHMPom., s. 45. 
Dziadkami Christiana Kersten ze strony ojca byli: Jürgen Kersten - kuśnierz i Maria Borken - córka sukiennika, a ze strony matki: Friedrich Carsburg - szewc, były burmistrz i Dorotea Belitzen - córka pastora.

1. Oryginał, perg., $438 \times 330 \mathrm{~mm}$; niem.

2. Stan dobry, przebarwienia na brzegach, dodatkowy pasek pergaminu pełniący funkcję plicy; przywieszona pieczęć [rady miejskiej?]: niebieska zdobiona tasiemka, pieczęć okrągła, woskowa, czarna, śr. 37 mm, w drewnianej puszce, wizerunek: połowa sylwetki orła z głową zwróconą w prawo, połowa koła [przypominające koło zębate], na obwodzie tekst „CIVITATIS N[EU] FRIDLAND POL[NISCHES?]”.

3. [B] GeburhtsBrief des Erb[aren] Christian Kersten eines Schneider aus Neu Friedland in Groß Pohlen gebührtig. illat [um] d[en] 22 Sept[em]b[e]r 1728; [D] 5258; Neu Friedland, Juli [sic!] 1727.

4. -

5. Kat. III, 5258.

6. BurgeMeister und Raht daselbst.

NR 51

1727, 21 XII Mirosławiec

Friedland in Groß Pohlen, d[en] 21 Decemb[er] 1727

Burmistrz i rajcy miasta Mirosławiec wydają zaświadczenie dla Christiana Kersten - krawca, wyuczonego u mistrza Friedricha Schmidte w Drawsku Pomorskim (Dramburg), że jego rodzice i dziadkowie są/byli wolno urodzeni i są/byli mieszczanami w Mirosławcu.

1. Oryginał, pap., bifolium, $200 \times 327 \mathrm{~mm}$; niem.

2. Stan dobry, plamki na całym arkuszu; pieczęć miejska papierowo-lakowa, czerwona, popękana, owalna, $39 \times 44 \mathrm{~mm}$, wizerunek jak w liście nr 50; znak wodny - herb rodu von der Goltz, halabardziści jako trzymacze - nierozpoznany.

3. [D] 5266; Friedland. D[ece]mb[e]r. 1727. Geburtsbrief des Schneider (gestellen?) Christian Kersten.

4. -

5. Kat. III, 5266.

6. Burgermeister und Rath. 
NR 52

1736, 13 VII Mirosławiec

(...) so geschen Friedlandt in Großpohlen d[en] drey zehnten July des Ein Tausend Sieben Hundert und sechs und drey Sichsten Jahr

Burmistrz i rada miasta Mirosławiec w Wielkopolsce wydają Condratowi Marcus (kupiec handlujący przyprawami korzennymi); synowi Johana Marcus - dzierżawcy na tamtejszym zamku i Elisabeth Tetzlaff - córki dzierżawcy Georga Tetzlaff; świadectwo dobrego urodzenia, co potwierdzili świadkowie: pastor z Karsiboru (Kesburg) Jochim Föge i Erdman Troje - dzierżawca z Rudek (Hoffstädt). Dziadkami Condrata Marcus ze strony ojca byli: Christian Marcus - dzierżawca i Christina Gusin, a ze strony matki Georg Tetzlaff - dzierżawca z Ladzina (Rehberg) i Maria Sidoin.

1. Oryginał, perg., $610 \times 351+52 \mathrm{~mm}$; niem.

2. Stan dobry; przywieszona pieczęć miejska: plica, żółta tasiemka, pieczęć okrągła, woskowa, czarna, śr. $42 \mathrm{~mm}$, w drewnianej puszce (bez przykrywki), wizerunek jak na pieczęci przy liście nr 50.

3. [B] Conrad Marcus ein Gewürtz kramer. Illatum d[en] 30 Aug[ust] 1737; [D] 5411a; 13. Juli 1736, Conrad Marcus gewürtz krämer. Friedland.

4. -

5. Kat. III, 5411a.

6. Wir Burgermeister und Rahtt; ErttMan Troje, Consul.

NR 53

1770, 22 V Mirosławiec

Friedland d[en] 22 Maji 1770

Friedrich Wilhelm Johann von Blankenburg prosi o ustanowienie kuratora dla spadku po byłym mieszczaninie Mirosławca - stolarzu Johannie George Lucas i jego żonie Annie Catharine zd. Hahnin (zmarła kilka lat wcześniej) - dla ich synów mieszkających w Mirosławcu, stolarzy: Johanna Heinricha Lucas i Johanna Christiana Lucas.

1. Oryginal, pap., bifolium, $203 \times 340+202 \times 340 \mathrm{~mm}$; niem. (adres - fr.).

2. Stan dobry, ślady złożenia; pieczęć zabezpieczająca - sygnetowa, lakowa, czerwona, owalna, $17 \times 20 \mathrm{~mm}$, wizerunek - na tarczy trzymanej 
przez lwy [?] głowa kozicy [koziorożca?], jako klejnot ptak z rozpostartymi skrzydłami; znaki wodne: 1.k. inicjały „ISG”, 2.k. pal [?] wewnątrz podwójego stylizowanego otoku zwieńczonego koroną [?] - oba nierozpoznane.

3. [A] $N$ [?] Meshieurs |Meshieurs le President, Bourgnemaitres et Senatores de la bonne ville á Thorn; [B] a Friedlandte; Litt[era] des Herr v[on] Blankenburg $\mid$ die Erbportion des E. [?] Lucas betest | lect [um] d[en] 6 Juny 1770.; 4; 5; 2; $b ; 24 ; 3$ [ostatnie trzy czerwony atrament]; [D] 22/5 70; $169 \div 170$; $195 \div 196 ; 5$.

4. -

5. Kat. II, I-3344; s. $169+196$.

6. FWJob v Blanckenburg $m p p$.

\section{NR 54}

1771, 24 III Mirosławiec

Friedland d[en] 24. Martii 1771

Friedrich Wilhelm Johann von Blankenburg z Mirosławca prosi radę miasta Torunia o interwencję w sprawie odzyskania 400 marek $(m k)$ należnych mu od mieszczanina toruńskiego i stolarza Johanna Heinricha Lucas.

1. Oryginal, pap., bifolium, $200 \times 341+201 \times 341 \mathrm{~mm}$; niem. (adres - fr.).

2. Stan dobry, ślady złożenia; pieczęć zabezpieczająca papierowo-lakowa, czerwona, owalna, śr. ok. $28 \times 31 \mathrm{~mm}$, wizerunek herbu Mirosławca (na czteropolowej tarczy na ukos krzyże maltańskie i głowy koziorożców), niedokładnie odciśnięta, na obwodzie czytelne jedynie „CIVIT” - podobna do HMW, B-411; znaki wodne: 1.k. stojący na zdobionej podstawie ryczący lew skierowany w lewą stronę patrzącego, głowa zwrócona w prawo, 2.k. inicjały: "I O E” - oba nierozpoznane.

3. [A] $N$ [?] Meshieurs | Meshieurs les President, Bourgnemaitres et Senateures de la bonne ville á Thorn; Franco (u/v); [B] Litt[era] des Jan v[on] Blankenburg. die Erbportion des Tischler Lucas betr[effend] d[en] 5 April. 1771.; [D] $24 / 371$; $29 \div 30 ; 63 \div 64 ; 3$ [przekreślona].

4. -

5. Kat. II, I-3311; s. $29+64$.

6. FWJob v Blanckenburg. 


\section{NR 55}

1782, 26 VII Mirosławiec

Friedland 26 VII 1782

Burmistrz i rada Mirosławca wydają list dobrego urodzenia Mich[a]elowi Lettau [tkacz], który na podstawie patentu króla pruskiego z 6 sierpnia 1732 r. może być przyjmowany do cechów.

1. Oryginał, pap., formularz drukowany, $440 \times 365 \mathrm{~mm}$; niem.

2. Stan dobry, nierówno przycięty; pieczęcie: 2 stemple drukowane - skarbowy i identyczny ze stemplem 1 . w liście nr 2, pieczęć lakowa, czerwona, okrągła, śr. ok. $34 \mathrm{~mm}$, znacznie uszkodzona, wizerunek niemożliwy do rozpoznania, na obwodzie napis: „[...]VITATIS · FRIEDL[...]”; znaków wodnych brak.

3. [D] Friedland Juli $1782 \mid$ Geburtsbrief der Michael Lettau eines Webers [ołówek]; 6003.

4. -

5. Kat. III, 6003.

6. Burgermeistere und Rath $U \mid V$. Radecke; H. Wiegenstoch [-stors?].

\section{NR 56}

1784, 3 X Mirosławiec

Friedland in Westpreussen 3 X 1784

Bractwo cechowe płócienników w Mirosławcu zaświadcza, że okaziciel niniejszego listu - urodzony w Mirosławcu [Franz] Michael Lettau - pobierał naukę rzemiosła przez 3 lata (29 września 1781-3 października 1784) u mistrza Fridricha Drenck Rahm.

1. Oryginał, pap., formularz drukowany $\mathrm{z}$ ozdobnym inicjałem, $442 \times$ $\times 371 \mathrm{~mm}$; niem.

2. Stan dobry, nierówno przycięty; pieczęcie: 3 stemple drukowane - skarbowa, „inicjał” i identyczna ze stemplem 1 . w liście nr 2, pieczęć lakowa, czerwona, okrągła, śr. ok. $38 \mathrm{~mm}$, wizerunek tarczy herbowej z trzema czółenkami tkackimi ułożonymi w trójkąt, wewnątrz którego znajdują się dwa zgrzebła, nad tarczą data 1689 [cyfra 9 jest przedstawiona w lustrzanym odbiciu], na obwodzie napis: „SIGILLVM · LINTEONVM · CIVITATIS · FRIDLANDENDIS .”; znaków wodnych brak. 
3. [D] Friedland i I W[est]pr[eußen] October 1784 Lehrbrief des Züchnergesellen Franz Michael Lettau [ołówek]; No 6019.

4. -

5. Kat. III, 6019/1.

6. Uchnahe [?] qua Ashesor; Friedrich Pend Eltermann; David Klein Cumpan.

\section{NR 57}

Bractwo cechowe płócienników w Mirosławcu zaświadcza, że okaziciel niniejszego listu - urodzony w Mirosławcu [Franz] Michael Lettau - pobierał naukę rzemiosła przez 3 lata (29 września 1781-3 października 1784) u majstra Fridricha Drenck Rahm.

1. Kopia, pap., formularz drukowany z ozdobnym inicjałem, $444 \times 374 \mathrm{~mm}$; niem.

2. Stan dobry, nierówno przycięty; stempel drukowany - identyczny ze stemplem 1. w liście nr 2, pieczęć lakowa, niedokładnie odciśnięta, patrz opis pieczęci w liście nr 56; znaków wodnych brak. Drukowany nagłówek COPIA.

1. [D] Friedlandi/W[est]pr[eußen] October 1784 LehrbriefdesZü̈hner=gesellen Franz Michael Lettau [ołówek]; ad No 6019.

3. -

4. Kat. III, 6019/2.

5. Uchnahe [?] qua Ashesor; Friedrich Pend Eltermann; David Klein Cumpan.

\section{NR 58}

1788, 22 III Mirosławiec

Märk[i]sch Friedland d[en] 22-te Mertz 1788

Kurator sądu patrymonialnego Conrad zwraca się do rady miasta Torunia w sprawie wyjaśnienia kwestii wysokości spadku przypadającego na dzieci po 
Johannie Heinrichu Lucas (syn mistrza stolarskiego Johanna George Lucas i Elisabeth zd. Hahnin).

1. Oryginał, pap., bifolium, $201 \times 333+199 \times 333 \mathrm{~mm}$; niem.

2. Stan dobry, ślady złożenia; pieczęci brak; znaki wodne: $1 . k$. herb trzymany przez 2 postacie, niewyraźny, całość wewnątrz ozdobnego ornametu, 2.k. inicjały „CFS” - oba nierozpoznane.

1. [C] No. 103 [d]; [D] 22/3 88.; $483 \div 485 ; 3 ; 243 ; 244$ [ostatnie trzy przekreślone].

3. -

4. Kat. II, I-3313; s. 483-486.

5. Ashocürt Adelich Creys Gericht | Conrad.

\section{NR 59}

1789, 15 VIII Mirosławiec

Märk[i]sch Friedland d[en] 15e August 1789

Kurator sądu patrymonialnego Conrad zwraca się do sądu miejskiego Torunia w sprawie roszczeń bauera Fentz, któremu Levie Abraham - kupiec żydowski z Torunia - za pośrednictwem Żyda Johema Marcusa i jego synów, dostarczył o 3 Sässer za mało kawy; jednocześnie prosi o wiarygodne sprawdzenie dokładności wagi miejskiej i uzyskanie wyjaśnień od Levie Abrahama.

1. Oryginał, pap., bifolium, $2 \times 199 \times 331 \mathrm{~mm}$; niem.

2. Stan dobry, ślady złożenia; pieczęć lakowa, czerwona, okrągła, śr. ok. $33 \mathrm{~mm}$, na obwodzie napis: „ADELICHE - PATRIMONIEGERICHTS . EG[...] ZU HOFFSTAEDT” [Rudki między Wałczem i Mirosławcem], wizerunek przedstawia herb: $\mathrm{w}$ tarczy dwudzielnej $\mathrm{w}$ pas $\mathrm{w}$ pierwszym polu sylwetka lwa zwrócona w prawo, w drugim polu dwa lewe skosy, klejnot ze strusich piór; znaki wodne: 1.k. „goździk” podobny do znaku w liście nr 43 - różni się dolną częścią, 2.k. inicjały „CFS” - oba nierozpoznane.

3. [A] An den hochlöblichen Stadt Gerichte der Stadt Thorn; frig [?]; [B] lect[um] d[en] 26. Aug[ust] 1789; Subsidiae Schulze [?] der Ashocürt Adelichen Kreis Gericht zu Märk[isch]s Friedland, der Juden Levie Abraham [...] zulassen; 15 [przekreślona]; 3 [czerwony atrament]; [C] No 83 [2. str, d]; [D] 15/8 89; 85-86; $99-100 ; 3$; 44; 51 [trzy ostatnie przekreślone]. 
4. -

5. Kat. II, I-3314; s. $85+99$.

6. Ashocürt Adelich Creys Gericht | Conrad.

\section{NR 60}

Burmistrz i rada miasta Mirosławca w związku z listem [w załączeniu do tego listu] mistrza ciesielskiego z Torunia Martina Pecka (z 15 czerwca 1787 r.), w którym oskarża mistrza ciesielskiego i stolarza Krause o nieprawidłowy podział spadku [w 1783 r.] po jego ojcu - mistrzu murarskim w Toruniu, w wyniku czego pokrzywdzony został niepełnoletni brat Krausego, prosi o zbadanie kwestii związanych z tym spadkiem i oskarżeniem.

1. Oryginat, pap., bifolium, $199 \times 340+194 \times 340 \mathrm{~mm}$; niem.

2. Stan dobry, ślady złożenia; pieczęć zabezpieczająca lakowa, czerwona, okrągła, śr. ok. $34 \mathrm{~mm}$, popękana, wizerunek herbu Mirosławca na tle płachty, nad herbem pruski orzeł z berłem i mieczem w szponach siedzący na koronie, u dołu napis: „STADT M: FRIEDLAND”40; znaki wodne: 1.k. pruski orzeł w koronie $\mathrm{z}$ berłem i mieczem w szponach, poniżej napis „NEU BERLIN”, 2.k. napis [częściowo zasłonięty pieczęcią] „GMEISSNER" - prawdopodobnie papiernia w Barlinku ${ }^{41}$.

3. [A] An Einen HochEdlen Magistrat der Stadt Thoren; postfrei; [B] lect [um] d[en] 24. Oct[ober] 1791; Schreibe des Magistrats [..] Märk[i]sch Friedland, den G. [?] Peck betreffend.; 8; 3 [czerwony atrament]; [D] 15 / 10 91.; 501

4. - 502; 525 - 526; 5 [przekreślona].

5. Kat. II, I-3347; s. $501+526$.

6. Burgermeister und Rath Horrce [?].

40 Najpewniej to o tej pieczęci pisze M. Gumowski, PiHMPom., s. 46.

41 W Wąsoszu koło Złotowa w latach osiemdziesiątych XVIII w. papier wytwarzali: Chrystian Karol Bogumił Meissner oraz niejaki C. G. Meissner. Por. F. Pabich, Papiernie nadnoteckie, s. 292; tenże, Dzieje ztotowskiej papierni w Wąsoszu, s. 186-188. 
NR 61

1724, 17 II Mrocza

Się działo się w mroci Roku Pańskiego tisiącnego siedemsetnego dwudziestego czwartego dnia siedemnastego lutego

Cech garncarzy w Mroczy wydaje Wawrzyńcowi Sarepskiemu, czeladnikowi mistrza Wawrzyńca Kurciusa, list nauki zawodu, informując jednocześnie, że spełnił wszelkie wymagane powinności.

1. Oryginał, pap., $337 \times 217 \mathrm{~mm}$; niem., pol.

2. Stan dobry, plamy atramentu; pieczęć papierowo-woskowa, czerwona, okrągła, śr. ok. $33 \mathrm{~mm}$, na obwodzie napis: „SIGIL - CONTVBER . [...] - LOBZ: [...]”, wizerunek dzbana z uchwytem i dzióbkiem stojącego na ozdobnej kolumnie; znak wodny: baranek „wielkanocny” zwrócony w lewą stronę patrzącego, stojący na ozdobnej podstawie, przednią nogą przytrzymujący proporzec z krzyżem maltańskim - nierozpoznany ${ }^{42}$.

3. [D] Mroczen 17. Febr[uar] 1724 [ołówek]; Lehrbrief des Töpfers Lorenz Sarepski [niebieski ołówek]; 5203 [czarny atrament].

4. -

5. Kat. III, 5203.

6. Pan Wocieh Sto[.]cik - cechmistrz garncarski; Pan Marcin Ocupowic; Jan Ceresnicky; Wawrziniec Kurceski-Pisarz Bracki.

\section{NR 62}

1404, 5 IX Nakło nad Notecią datum in Nakel fer[ia] sexta post fest[em] Sancti Egidi [Aegidi]. Abbat[em] Anno d[omi]ni milles[imo] quadriigen[tesimo] quarte

Wójt i rajcy miasta Nakło polecają radzie miasta Torunia Stephanusa.

1. Oryginał, pap., $223 \times 130 \mathrm{~mm}$; łac.

2. Stan dobry (konserwacja 1999 r.), ślady złożenia; resztki i ślady pieczęci woskowej, brązowej, okrągłej, śr. ok. $34 \mathrm{~mm}$, niezbyt czytelna - wizeru-

42 Podobieństwo do filigranu Pascala Laniba z 1755 r., najpewniej „,baranek” był filigranem konwencjonalnym. Por. С. А. Клепиков, dz. суt., s. 272, fil. 1118. 
nek bramy miejskiej z dwoma wieżami, a między nimi przyłbica rycerska z pióropuszem [?], na obwodzie widoczne tylko litery: „N R [lub K?]”. Zob. HMW, B-419 i 421, s. 384. Znaku wodnego brak. Przechowywany w porto folio.

3. [A] Vnep[o]denti consilio s[f-?]olege[ne-?]ribus din[n]s Proconsuli et consulibus Torunn civitate Randisiae pnt [w tym miejscu umieszczono symbol astronomiczny Jowisza].

4. -

5. Kat. III, 4184.

6. Advocate et Consules tota q[ue] om [n]itas civitat[es] Nakl[e]n form.

\section{NR 63}

1777, 20 IV Nakło nad Notecią

Nakel d[en] 20te April 1777

Urzędnik sądowy z Nakła nad Notecią prosi magistrat toruński o przygotowanie pozwu przeciwko kupcom Kaltersbach i Zachert i przesłaniu jego kopii do magistratu w Fordonie.

1. Oryginat, pap., bifolium, $201 \times 345+200 \times 342 \mathrm{~mm}$; niem.

2. Stan dobry, ślady złożenia; pieczęci brak; znaki wodne: rozkład i wzór identyczne jak w liście nr 43 („goździk” i „Madonna”), jedyna różnica w „goździku” - zamiast inicjałów „ICM” widnieją „I[F]S” - Jan Fryderyk Sachse, papiernia w Buszkowie koło Koronowa(? $)^{43}$.

3. [C] In acheroint [?] [lg]; Requirt: $30 /$ p[er] Mundo 7[.] [ld]; -7[.] - 9d| [pod poziomą kreska:] - 37-9d [ld]; [D] 20/4 77; $411 \div 412$; $421 \div 422$; 3;

4. -

5. Kat. II, I-3311; s. $411+422$.

6. S[.]octt [?].

43 Por. F. Pabich, Papiernie nadnoteckie, s. 291. 


\section{NR 64}

1785, 4 VI Nakło nad Notecią

Nackel den 4 Juny 1785

Burmistrz i rada Nakła nad Notecią, w odpowiedzi na pismo magistratu toruńskiego z 13 i 20 maja 1785 r., oświadczają, że kupiec Gottlieb Zander przez rok mieszkał i prowadził interesy w Nakle, jak również opłacał podatki królewskie i miejskie - przy czym zastrzegał możliwość przeprowadzki do innego miasta w królestwie.

1. Oryginał, pap., bifolium, $200 \times 341+204 \times 341 \mathrm{~mm}$; niem.

2. Stan dobry, ślady złożenia; pieczęć zabezpieczająca papierowo-opłatkowa, niedokładnie odciśnięta, śr. ok. $33 \mathrm{~mm}$, wizerunek murów miejskich z dwiema basztami i wieżą nad bramą; znaki wodne: 1.k. napis „MARIENWERDE[R]”, 2.k. stylizowany orzeł pruski z berłem i jabłkiem w szponach z inicjałem „R” na piersi - papiernia w Kwidzynie.

3. [A] An E. Wohlweisen Magistrat zu Thoren; [B] Antworts Schreibe der Nackelschen Magistrats, ab der G. Zander dort das Bürger recht erhalte hat.; lect[um] d[en] 10 Jun[i] 1785.; 2; 4; 10; 13 [czerwony atrament]; [D] 4 / 6 $85 ; 597 \div 598 ; 625 \div 626 ; 5$.

4. -

5. Kat. II, I-3346; s. $597+626$.

6. Burgermeister und Rath | Burgaedel [?]; Wegnes.

\section{NR 65}

1608, 30 IV Piła

Datum in Oppidi Piela dei 30 Mensis Aprilis Anno $\mathrm{D}$ [omi]ni millesimo 60 octavo

Jan Węgórczyk i Marcin Ptaszek - starsi cechu zdunów i garncarzy w mieście Piła zaświadczają, że Paweł [Buczkowski], syn Bartosza (członka cechu), wyuczył się rzemiosła u swego ojca i spłacił wszelkie zobowiązania wynikające z nauki zawodu.

1. Oryginał, pap., bifolium, $104 \times 170 \mathrm{~mm}$; pol.

2. Stan dobry, przedarcia na zgięciach, zapisana tylko pierwsza strona, lewy margines czysty; pieczęć miejska papierowo-lakowa, brunatna, krusząca się, okrągła, śr. $33 \mathrm{~mm}$, wizerunek biegnącego jelenia, na obwodzie 
tekst: „SIGILVM OPIG[!]I PILA ANNO 1540 [cyfra „4” stanowi swoje lustrzane odbicie]”. Zob. HMW, B-476, s. 396. Znak wodny: okrągły, wizerunek murów z trzema basztami, ozdobny wzór łączy szczyty skrajnych baszt, na obwodzie litery: „IKRPCSAN [...] AUS [...]” - najprawdopodobniej papiernia w Wąsoszu koło Złotowa ${ }^{44}$.

3. [D] 4643; Piela 1608 Zechebrief das Ofentögferis Paul Buczkowski (Schneidemühl?).

4. -

5. Kat. III, 4643.

6. Sebastianus, No[tarius] Iuratus Pub[lici] opp[idi] Pilen[sis].

NR 66

1774, 30 IX Piła

Actum Schneidemühl d[en] 30te Sept[em]b[e]r 1774

ZAŁĄCZNIK DO MEMORIAŁU RUTTICHA [członek Komisji Sprawiedliwości] DO MAGISTRATU TORUŃSKIEGO Z 29 XI 1774 r. [Kat. II, I-3427; s. 653-654]

Kopia protokołu sporządzonego i poświadczonego przez justycjariusza Grunenthal, zawierającego oświadczenie Żyda z Inowroctawia Davida Hirsch na temat okoliczności zatrzymania jego brata (na wniosek kupca toruńskiego Christiana Blümcke) Skulner Davida Guthmann przez władze toruńskie, oskarżonego o pozostawanie w „kompanii” z Żydem łobżenickim Salomonem Gabriel, o niejasności w transakcji handlowej i o nieoddanie części należności garbarzowi Nicolausowi Korn z Nowego Miasta Torunia.

1. Oryginał, pap., bifolium, $2 \times 205 \times 344 \mathrm{~mm}$; niem.

2. Stan dobry, ślady złożenia; pieczęci brak; znak wodny: tylko 2. karta „Strassburg”, zwieńczona koroną książęcą tarcza z wizerunkiem lilii, poniżej inicjały: „MWM” - nierozpoznany.

3. [C] Copia; [D] $661 \div 662 ; 667 \div 668$.

4. -

5. Kat. II, I 3427; s. $661+668$.

6. Grunenthal $\mid$ Justitz Amtmann.

44 Por. Rękodzieto, s. 268 oraz s. 332, tablica III, fil. 29. 
NR 67

1776, 4 X Piła

Schneidemühl d[en] 4te October 1776

Sąd landwójtowski w Pile zawiadamia o ogłoszeniu upadłości i rozpoczęciu postępowania wobec wierzycieli byłego landrata [Christiana] von [der Osten -] Sacken z Clausdorf [Kłębowiec koło Wałcza] trwającego do 18 lutego 1777 r., do którego kwalifikuje się kupiec toruński Johann Bahrend.

1. Oryginał, pap., bifolium, $2 \times 203 \times 360 \mathrm{~mm}$; niem.

2. Stan dobry, ślady złożenia; 2 stemple drukowane, pieczęć papierowo-opłatkowa, okrąła, śr. ok. 36 mm, wizerunek pruskiego orła w koronie z jabłkiem i berłem w szponach, na obwodzie napis: „KON: PR: LANDVOGTEY · GERICHT ZU SCHNEIDEMÜHL”; znaki wodne: 1.k. „kwiat w wazonie”, 2.k. inicjały „ICM” - oba nierozpoznane ${ }^{45}$.

3. [B] dieses durchgelesen zu haben attestion Thorn d[en] $23 n$ Xbris (sic!) 1776. Johann Barendt; [C] No. 205e [d]; Pirschel [pd]; [D] 211; 213.

4. -

5. Kat. II, I-3316; s. 211-214.

6. J. Salomon; [luka]; Schaminik; Guberlk[...].

\section{NR 68}

1776, 30 XI Piła

Schneidemühl den 30te November 1776

Sąd landwójtowski w Pile prosi magistrat toruński o zapoznanie się z załączoną listą wierzycieli, potwierdzenie i odesłanie w związku ze sprawą ogłoszenia upadłości byłego landrata [Christiana] von [der Osten -] Sacken.

1. Oryginat, pap., bifolium, $205 \times 355+207 \times 355 \mathrm{~mm}$; niem.

2. Stan dobry, ślady złożenia; 2 stemple drukowane, pieczęć zabezpieczająca, lakowa, czerwona, okrągła, śr. ok. $26 \mathrm{~mm}$ - patrz opis i rysunek pieczęci w liście nr 67; znaki wodne: 1.k. inicjały „ICM”, 2.k. „kwiat w wazonie” - oba nierozpoznane ${ }^{46}$.

45 Patrz przypis 26.

46 Tamże. 
3. [A] An Einen Hochlöblichen Magistrat in Thoren; Franco; [B] Subsidiat: das Landwogtey Gerichts zu Schneidemühl. lect[um] d[en] 23 [poprawione na 24.]; [C] Dec[ember] 1776; Eines Hochlöblichen Magistrats [1, pod treścią pisma]; No 266. [d]; Pirschel [pd]; [D] 30 / 11 76.; $209 \div 210$; $215 \div 216 ; 3 a$ [przekreślona].

4. -

5. Kat. II, I-3318; s. $209+216$.

6. Königl[iche] WestPreuß[ische] LandVogthey Gericht|J. Salomon; Burghof; Schaminik; Guberlk[...].

\section{NR 69}

1781, 22 IX Piła

zu Schneidemühl den 22te September 1781

Sąd landwójtowski w Pile prosi magistrat toruński o jak najszybsze dostarczenie poświadczonej kopii orzeczenia w sprawie kupca Berkau przeciw Żydowi Abrahamowi Fonas.

1. Oryginał, pap., bifolium, $206 \times 351 \mathrm{~mm}$; niem.

2. Stan dobry, ślady złożenia; 2 stemple drukowane; znak wodny: pruski orzeł ze stylizowaną koroną, z berłem i jabłkiem na szponach, poniżej napis: „KPHSTVKC” - nierozpoznany.

1. [C] No. 335. [d]; Pirschel. [pd]; [D] 22 / 9 81.; 511; 3a [przekreślona].

3. -

4. Kat. II, I-3320; s. $511+$ brak.

5. Königl[iche] WestPreuß[ische] Land Woigthey Gericht zu Schneidemühl| J. Salomon; [luka]; E. Lermont [?]; Schmid [?].

NR 70

1792, 15 XII Piła

Schneidemühl d[en] 15te December 1792

Magistrat w Pile zwraca się z prośbą do magistratu toruńskiego w sprawie wyjaśnienia okoliczności ucieczki czeladnika rębacza rzeźnickiego Carla Friedericka Welks od mistrza Steinmetz, który to czeladnik zjawił się kilka tygodni wcześniej przed pilskim urzędem (z pismem potwierdzającym jego 
pracę, wystawionym przez cech rębaczy rzeźnickich w Toruniu z dnia 20 lutego 1792 r.).

1. Oryginal, pap., bifolium, $190 \times 332+195 \times 332 \mathrm{~mm}$; niem.

2. Stan dobry, ślady złożenia; pieczęć zabezpieczająca lakowa, czerwona, okrągła, śr. ok. $26 \mathrm{~mm}$, wizerunek właściwie nie do rozpoznania, najpewniej herb Piły - biegnący jeleń, na obwodzie napis: „SIEGEL D · MAGISTRATS ZU SCHNEIDEMUHL ." ${ }^{37}$; znaki wodne: 1.k. pruski orzeł w koronie, poniżej napis „COS[.]SEN[.]”, 2.k. inicjały: „IFM” - Jan Fryderyk Meller, papiernia w Będominie(? ${ }^{48}$.

3. [A] Einem Wollöb[lichen] Magistrat des König[lichen] Stadt Thoren; [B] Schr[ift] des M[a]g[is]t[rat]s v[o]n Schneidemühl e[inen] dort entlauf[enden] Fleische Welks gehalten betr[efft]; lect[um] d[en] 28 Dec[ember] 1792.; 34; Er= [?]; [D] 1792/5 [niebieska kredka]; 15.12.92.; $663 \div 664 ; 697 \div 698 ; 5$.

4. -

5. Kat. II, I-3347; s. $663+698$.

6. der Magistrat | Hans Clericus [?].

\section{NR 71}

1793, 28 II Piła

Schneidemühl im Netz District d[en] 28-e Febr[uar] 1793

Radca komisji sądowej Hackebeck w związku z postępowaniem spadkowym po siostrzeńcu babki aptekarki (Medicin Apothequer) Seidener zd. Hollizin - Carlu Friedrich Winter (mieszkał w Gubinie [Guben]) prosi magistrat toruński o sprawdzenie: 1) czy w szpitalu św. Piotra i Pawła w Toruniu zmarła wdowa Catharina Elisabeth Pillipin zd. Kohlheis (siostra matki Seidener [ciotka])?; 2) czy konieczne jest wystawianie aktu zgonu brata tej wdowy - Jacoba Friderick Kohlheis, który utonął w Wiśle [?] w Toruniu?; 3) czy wdowa ta miała jeszcze innych krewnych oprócz brata i siostry (matki Seidener)?

47 Najpewniej jest to pieczęć opisywana przez M. Gumowskiego, PiHMWlkp., s. 244.

48 Por. F. Pabich, Autor nieśmiertelnego Hymnu Narodowego, Józef Wybicki-budowniczym papierni w Będominie w powiecie kościerskim, Przegląd Papierniczy, t. 258, nr 7, 1965, s. 219; tenże, Filigrany papierni kaszubskich. Ze zbiorów Franciszka Pabicha, Chojnice 1977 , fil. 1 . 
1. Oryginał, pap., bifolium, $357 \times 234 \mathrm{~mm}$; niem.

2. Stan dobry, ślady złożenia, w 2 . karcie uszkodzenia mechaniczne; pieczęci brak; znak wodny: „Horn”, poniżej napis: „D\&C BLAUW” - nierozpoznany.

3. [D] 28 / 2. 93.; $691 \div 693$; 347; 348; 3 [dwa ostatnie przekreślone].

4. -

5. Kat. II, I-3314; s. $691+694$.

6. Hackebeck $\mid$ Königl[iche] Preus[sische] Justi[z] Comiesions Rath.

NR 72

1793, 18 III Piła

Schneidemühl im Netz District d[en] 18ten Merz 1793

Radca komisji sądowej Hackebeck ponawia prośbę o przesłanie faktów w sprawie spadkowej po krewnym aptekarki Seidener [patrz list nr 71].

1. Oryginał, pap., bifolium, $206 \times 328+206 \times 327 \mathrm{~mm}$; niem.

2. Stan dobry, ślady złożenia; pieczęć zabezpieczająca, lakowa, czerwona, okrągła, śr. ok. $28 \mathrm{~mm}$, niedokładnie odciśnięta, wizerunek - pruski orzeł w koronie z berłem i mieczem w szponach, poniżej napis: „[KÖ]N[: ]P[REUSS: J]UST[IZ · RA]T[H .] [...]” [?]; znaki wodne: 1.k. pruski orzet w koronie z berłem i mieczem w szponach, 2.k. inicjały „JFM” - Jan Fryderyk Meller, papiernia w Będominie? ${ }^{49}$.

3. [A] An die Wobllöbl[ichen] Und Hochweisen Magistrat zu Thorn; frei ln [?]; [B] Schr[ift] des Justiz Com [mission] Rath Hackebeck, die Wesitelitin[?] Kohlheisin betr[eft] lect[um] d[en] 22 Mart[ii] 1793.; 31.; fir. [?]; 2 [czerwony atrament]; [D] 18.3.93; 697; 715 $\div$ 716; 350; 359; 3 [trzy ostatnie przekreślone].

4. -

5. Kat. II, I-3314; s. $697+715$.

6. Hackebeck|Kreis Just[iz] Comiser Rath.

49 Patrz przypis do listu nr 70. 
NR 73

1407, 18 VI Sępólno

Krajeńskie
Sege zu Sampelborg des resten Sonowendess vor sinte Johnis Baptiste (...) sub anno domi[ni] millesimo $\mathrm{CCCC}^{\circ}$ septimo

Burmistrz i rajcy miasta Sępólno Krajeńskie zaświadczają, na wniosek starszych cechu piekarzy, że Niclos Polkiewicz - piekarz dobrze wywiązywał się ze swoich powinności w cechu.

1. Oryginal, pap., $294 \times 217 \mathrm{~mm}$; niem.

2. Stan dość dobry, zacieki po zalaniu wodą, brzegi postrzępione; pieczęci przywieszonej na papierowych paskach brak; znaku wodnego brak.

3. [A] Den ersamen Borg[er]meist[er] und Rathman[n]en und dem Werke: der Hokennbekker der Alden Stats Thorun wusu[.]viwen[.] hem put [...] en [...] Beverevaa[...].

4. -

5. Kat. III, 4247.

6. Der Borg[e]meist[er] und Rathman[n]e zu Sampelborg, uwer dyner Sorne[n].

\section{NR 74}

1764, 20 I Sępólno

Z Sempelborka. d[en] 20: January 1764

Krajeńskie

Komisarz Felix Christian Salvador zwraca się do magistratu toruńskiego w imieniu swego zwierzchnika - hrabiego ( grafa) [Aleksandra Hilarego] Potulickiego, starosty borzechowskiego - o zatrzymanie i osadzenie $\mathrm{w}$ areszcie przebywającego podobno $\mathrm{w}$ kamienicy kasztelanica gdańskiego [Antoniego] Kruszyńskiego, niejakiego Machta - komisarza grafa Potulickiego, oskarżonego o zagarnięcie dużej kwoty pieniężnej należącej do jego zwierzchnika.

1. Oryginał, pap., bifolium, $173 \times 210+170 \times 210 \mathrm{~mm}$; pol. 
2. Stan dobry, ślady złożenia; pieczęci brak; znak wodny: dwa, stojące na tylnych łapach, lwy podtrzymujące herb Gdańska - nierozpoznany ${ }^{50}$.

3. [D] 20/1. 64; 357 $\div 358 ; 371 \div 372$; 7 .

4. -

5. Kat. II, I-3420; s. $357+372$.

6. Felix Christian Salvador, Kommis mpp.

\section{NR 75}

1747, 4 VII Tuczno Datum Tucznae. Quaria Mensis Julii Anno Domi-
ni Millesimo Septingentesimo Quadragesimo Sep-
timo

Burmistrz i rajcy miasta Tuczno wydają na prośbę Johanna Isert i Lücke - mieszczan, świadectwo dobrego urodzenia dla Jacoba Radkiewicza; syna Jacoba i Cathariny Radkiewicz (którzy zawarli małżeństwo w obrządku rzymskokatolickim w kościele w Tucznie - sakramentu udzielił proboszcz Antoni Habisch), ochrzczonego również w tamtejszym kościele 23 lipca 1722 r., mającego za rodziców chrzestnych Laurentza Kryger i Mariannę Grodecką.

1. Oryginał, perg., $608 \times 491+50 \mathrm{~mm}$; łac.

2. Stan dobry, drobne plamy; przywieszona pieczęć miejska: plica, zielona wstążka, pieczęć okrągła, woskowa, bursztynowa, śr. ok. 34-36 mm, wizerunek głowy wołu z pierścieniem w nozdrzach, otoczona gałęziami palmowymi, nad nią korona, na obwodzie tekst „SIGILLVM CIVITATIS [T]UCZNIENSIS”. Zob. HMW, B-714, s. 448.

3. [B] Jacob Radkiewicz Geburts-Brief aus Tuczno illat[um] die 30. Augusti 1747; [D] 5607; Tuczno, Juli 1747.

4. -

5. Kat. III, 5607.

6. Johannes Kryger, Proconsul; Ad mandatum Spectabilis oficy Proconsularis Tucznensis Extradidit Christianus Leske, N[ota]rius juratus. 


\section{Krystian Chyrkowski}

Aneksy

\section{ANEKS 1}

\section{LIST NR 14}

Kat. II, I-3322, s. 475-494

Hoch- und Wohlgebohrene und Hochgelahrte Herren.

Insonders Hochzuehrende Herrn Bürgermeistern und Senatores!

Ein hiesiegen Färber Lüschner ${ }^{51}$ ist während seiner Abwesenheit nun hier, von verschiedenen seiner Glaubigen vor Aus belangt werden. Da nun derselbe, wie es heißt, sich unter Euer Hoch- und Wohlgebohren Jurisdiction aufhalten soll. So haben Hochdieselben wir in Subsidium Juris, und untern dem beigefügten vergebensten Versicherung unserer Berufwilligkeit zu allen rechtlichen Gegendiensten gantz gehorsuchnis sind und ersuchen wollen ${ }^{a}$ demselben die anliegenden Verfügungen hochgeneigt zustellen und uns die diesfällige Behändigungs Schein, sobald wie möglich gefälligst remittiren zu lassen.

Die wir mit vollkommensten Hochachtung uns zu nennen, die Ehre haben; Euer Hoch- und Wohlgebohren

ganz gehorsamste

Königliche Westpreußische Stadt Gericht

$$
\text { Sechs }^{52} \text { [?] Sisty }{ }^{53} \text { [?] NRvTrotter }{ }^{54}
$$

Jastro[w] $]^{55}, \mathrm{~d}[\mathrm{en}] 21$ May 1787.

An

Euer HochLöblichen Magistrat

$\mathrm{zu}$

Thoren

a Na wysokości 2 wierszy poniżej na lewym marginesie dwie ukośne kreski.

b Między nazwiskami Sisty i NRvTrotta występuje wyraźny większy odstęp.

51 Z tekstu: farbiarz z Jastrowia.

52 Z tekstu: członek sądu miejskiego w Jastrowiu.

53 Z tekstu: członek sądu miejskiego w Jastrowiu.

54 Członek magistratu i sądu miejskiego w Jastrowiu; por. notka biograficzna w indeksie geograficzno-osobowym.

55 Jastrowie - miasto na północ od Piły. 


\section{ANEKS 2}

\section{LIST NR 24}

\section{Kat. III, 5626/1}

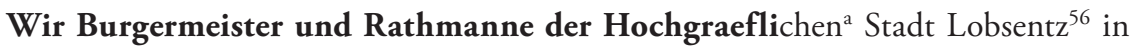
Groß-Pohlen belegen, fügen einem jeden in gebuhrendem Respect nebst offerto unserer freundwilligsten Dienste zu vernehmen, was massen $[s]$ vor uns im sitzenden Rath erschienen, Tit[ulo] Monsieur David Pannenberger ${ }^{57}$, und uns vorgebracht hat, wie er seiner zeitlichen Wohlfahrt wegen ein glaubwürdiges Testimonium und Kundschaft seiner ehrlichen Geburt oder Herkommens benötiget wäre: Zu dem Ende er zwei untadelhafte Zeugen aufgeführet, welche nahmentlich der wohlehrenveste ${ }^{\mathrm{b}}$ und großachtbare Tit[ulo] David Rohenau ${ }^{58}$, Bürger und Loß-Bäcker, wie auch E[ine] E[hrbare] Rathsmitglied alhier; und dann der wohlehrenveste und wohlachtbahre Tit[ulo] Martin Mannthej ${ }^{59}$ gleichsfal[1]s Bürger und Loß-Bäcker alhier. Diese, weil sie um gedachten Tit[ulo] David Pannenberges ehrlichen Geburt genaue Wissenschaft tragen, haben nach rechtlichen Befragen, so wie es sich zu Rechte gebührt mit entblösten Häupten ausgestreckten Fingern und einem Jurament fundamentaliter wahrgemacht, daß Vorzeiger dieses von seinem nochlebenden Vater dem Tit[ulo] George Pannenbergern ${ }^{60}$, hiesigem Bürger und Loß-Bäcker, auch von seiner leiblichen und natürlichen Mutter, der weiland wohlehrbar[e]n Tit[ulo] Catharina, geborner Geeringen ${ }^{61}$. Die beidenseits als christl[iche] Eheleute nach Gottes und der Christlichen Kirchenordnung zur Ehe sich verbunden, in einem keuschen und unbefleckten Ehebett, recht echt ehrlicher teutscher Nation und Herkommens, niemand mit Leibeigenschaft verwandt und verbunden, daselbst erzeuget, gebohren und getaufet und wohlverzogen worden, sich auch, so viel ihnen wissend, christlich, friedliebend und honette aufgeführt habe. Wann dann solch er Gestalt des Tit[ulo] Mons[ieur] David Pannenbergers ehrlich Geburt, wir auch gute Erziehung beglaubwürdiget und wahrgemacht werden, als gelanget an jedermänniglichen unser respective freundliche Bitten, Vorzeigen dieses in ihrer ehrliche Zünfte und Gewerke aufzunehmen, und ihn allen geneigten Willen genüssen zu lassen,

56 Łobżenica - miasto na północny wschód od Piły.

57 Piekarz, cukiernik, por. notka biograficzna w indeksie geograficzno-osobowym; być może krewny osób - patrz: Metryka uczniów toruńskiego Gimnazjum Akademickiego 1600-1817, cz. 2: (1798-1817), wyd. Z. H. Nowak, J. Tandecki, Toruń 1998, pozycje: 10 082, 10 182, $10641,10642$.

58 Z tekstu: mieszczanin i rajca w Łobżenicy, cukiernik; bliżej nieznany.

59 Z tekstu: mieszczanin i cukiernik z Łobżenicy; por. notka biograficzna w indeksie geograficzno-osobowym.

60 Z tekstu: mieszczanin i cukiernik z Łobżenicy; bliżej nieznany.

61 Osoba bliżej nieznana. 


\section{Krystian Chyrkowski}

das sind wir auch standes Erheischung zu demeri erbötig. Urkundlich haben wir dieses mit unsern Stadt-Insiegel und gewöhnlichen Unterschrift berkräftigen wollen. Datum Lobzenicae, die 8.Maj anno 1749.

L.S.

Michael Lindebein ${ }^{62}$ Procon[su]l Lobsener

mpp

Antonius Jacobus Kręczkiewicz ${ }^{63}$ Notarius Utriusque Officii Lobsen[ensis] Jur[is] ${ }^{c}$ mpp

a „e” z dyftongu nadpisane nad „a”.

b W oryginale „-weste”; patrz też wiersz 7.

c Poniżej w lewym dolnym rogu arkusza dopisana sygnatura archiwalna „56261”.

\section{INDEKS GEOGRAFICZNO-OSOBOWY}

Część geograficzna indeksu (hasła pisane kursywa) zawiera nazwy geograficzne występujące jedynie w opisach katalogowych. Pominięto hasło „Toruń” występujące w adresach i nagłówkach listów. Liczby przy hasłach oznaczają numer listu. W nawiasach kwadratowych [ ] podano oryginalne nazwy występujące w listach.

Część osobowa indeksu obejmuje nazwiska osób występujących w części katalogowej artykułu. Liczby przy nazwiskach oznaczają numer listu. Dla kobiet uwzględniono nazwiska rodowe; jeżeli były mężatkami, nazwisko męża podano po odsyłaczu. Końcówki niektórych nazwisk podano w nawiasach okrągłych ( ); w takich przypadkach istnieje brak pewności co do poprawnego brzmienia nazwiska rodowego. Symbol [?] oznacza brak pewności poprawnego odczytania imienia lub nazwiska. Znak zapytania - ? - w miejscu imienia oznacza, że jest ono nieznane.

Skróty:
c. - cech lub córka
(st.) - starszy (ojciec, dziadek)
o. - ojciec
st. c. - starszy cechu
m. - mieszczanin
ż. - żona
s. - syn

62 Burmistrz Łobżenicy; bliżej nieznany.

63 Pisarz urzędowy w Łobżenicy; bliżej nieznany. 
A

Abraham, Levie - kupiec 59

\section{B}

Babiński, Balcer - garncarz, brat stołowy 17

Bahrend, Johann - kupiec toruński 67

Banzener [?], Paul David - młynarz 16

Barchard, ? - krawiec $4 \mathbf{6}$

Barlinek [Berlinschen, Neu Berlin] 6, 60

Batorowo [Batorae] $\mathbf{1 8}$

Belitz, Dorotea - ż. $\rightarrow$ Friedrich Carsburg 50

Bellach, Grieger - s. Jacoba, bakałarz 21

Bellach, Jacob - słodownik 21

Bellach, Johann Gottlieb - s. Griegera 21

Berkau, ? - kupiec 69

Będomin-papiernia 70, 72

Bielański, Bartłomi[ej] - garncarz 17

von Billerbeck, C. [?] - porucznik, landrat - w 1775 r. w powiecie inowrocławskim, w 1782 r. w powiecie kamieńskim (najprawdopodobniej w 1783 r. usunięty ze stanowiska za nieudolne zarządzanie powiatem); dyrektor fortyfikacji w Grudziądzu [brak potwierdzenia]; współwłaściciel wsi Dombia koło Kamienia Krajeńskiego [Westpreussen, Bd. 2, s. 284; Wirsitz, s. 42] 42-45

von Blankenburg, Friedrich Wilhelm Johann - członek starego rodu niemieckiego, herbu Topacz, ewangelik, polski pułkownik (Oberst), właściciel Mirosławca i okolicznych wsi [Westpreussen, Bd. 2, s. 760; von Żernicki, s. 45-46] 53, 54

Bleymann, Charlotta - ż. $\rightarrow$ Christoph Wolffschläger 6

Block, Gottfriedt - sukiennik z Czaplinka, otrzymał prawo miejskie Torunia 10 października 1770 r. [APT, II, I-55, s. 202, poz. 881] 5

Block, Heinrich - sukiennik z Czaplinka, otrzymał prawo miejskie Torunia 20 czerwca 1755 r. [APT, II, I-55, s. 160, poz. 714] 3

Blümcke, Christian - kupiec toruński 66

Boht, Fried - sukiennik 10, 12

Bork(en), Maria - c. sukiennika, ż. $\rightarrow$ Jürgen Kersten $\mathbf{5 0}$

borzechowski, starosta 74

Borzz [?], ? - pisarz sądowy 32, 34-39

Boys, Johann Jacob - sędzia 2, 4

Brocz, Barbara - ż. $\rightarrow$ Andreas Mittelstät 1 


\section{Krystian Chyrkowski}

Buczkowski, Bartosz - garncarz/zdun 65

Buczkowski, Paweł - s. Bartosza, garncarz/zdun 65

Burgaedel [?], ? - urzędnik magistratu 64

Burghof, ? - radca sądu landwójtowskiego w Łobżenicy (w latach 1773-1775) i w Pile (od 1775 do minimum 1776) [Westpreussen, Bd. 1, s. 148, 379; Eobżenica, s. 124; Wirsitz, s. 55] 32-35, 37-41, 68

Buss(in), Anna Maria - ż. $\rightarrow$ Mathaus Hahn 18

Buszkowo - papiernia 63

Bydgoszcz 43

C

Camen $\rightarrow$ Kamień Krajeński

Carsburg, Dorotea - c. Friedricha, ż. $\rightarrow$ Christian Kersten (st.) 50

Carsburg, Friedrich - szewc, burmistrz 50

Ceresnicky, Jan - garncarz 61

Chappe, ? - pisarz sądowy 33

Cholevius, Johann - s. Michaela, krawiec, sukiennik z Łobżenicy, otrzymał prawo miejskie Torunia 20 grudnia 1720 r. [APT, II, I-55, s. 47, poz. 278] 20

Cholevius, Michael - rajca 20

Cieszyno [Teschendorfe] $\mathbf{1}$

Clausdorf $\rightarrow$ Ktębowiec

Clericus [?], Hans [?] - urzędnik magistratu 70

Colberg $\rightarrow$ Kotobrzeg

Conrad, ? - kurator sądowy 58, 59

Cortmann $\rightarrow$ Kortmann

Cotlen $\rightarrow$ ? 18

Cuno, ? - skarbnik miejski 3, 5

Czaplinek [Tempelburg] 1-5

Czarnowo 42, 44

Czechyń [Zechendorf] $\mathbf{8}$

Cztopa $[$ Schloppa $] \mathbf{6}$

\section{D}

Daugs, Laurentz - m., st. c. rzeźników 1

Debrzno [Preussischen Friedland] 21

Dębionek [Dembionke] 21 
Dibbel(in), Anna Lucia - ż. $\rightarrow$ Jacob Olbötter 1

Draheim $\rightarrow$ Stare Drawsko

Drawsko Pomorskie [Dramburg] 51

Dudkawicz, Antoni - garncarz 17

Dumck, Gabriel - inspektor leśny 4

Düg(en), Anna - ż. $\rightarrow$ Johann Jaster 7

E

Eggert, Jacob - kamerdyner 42-45

Elblag-papiernia $\mathbf{1 1}$

Eveitsch, Anna Magdalena - ż. $\rightarrow$ Michael Cholevius 20

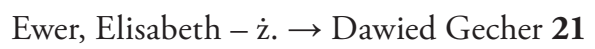

$\mathbf{F}$

Falkenburg $\rightarrow$ Ztocieniec

Fancke, Peter - sukiennik 4

Fenger, Johann (st.) - burmistrz 19

Fenger, Johann - s. Johanna, kupiec z Łobżenicy, otrzymał prawo miejskie Torunia 22 marca 1720 r.; zajmował się handlem wiślanym, członek toruńskiego III Ordynku, ławnik sądu przedmiejskiego; żonaty z Anną Elisabeth z domu Nogg, ojciec Jacoba; zmarł przed 1758 r. [APT, II, I-54, s. 102, poz. 513; APT, II, I-55, s. 43, poz. 261; HT, s. 41] 19

Fentz, ? - rolnik 59

Ferber, Jacob - mieszczanin 6

Fiebich, Andreas - tkacz 21

Flatow $\rightarrow$ Ztotów

Fonas, Abraham 69

Fordon- 63

Föge, Joachim - pastor w Karsiborze w latach 70. i 80. XVIII w. [Bąk, s. 204] 52

Fredland $\rightarrow$ Mirostawiec

Friderici, Christoph - burmistrz 2-5

Fried $(t)$ land $\rightarrow$ Mirostawiec

G

Gabriel, Salomon - st. gminy żyd. 38-40, 66

von Garizynski [?], Jacob 35, 36 
gdański, kasztelanic $\mathbf{7 4}$

\section{Gdańska, Zatoka-papiernie 11}

Gecher, Anna Maria, c. Dawieda, ż. $\rightarrow$ Grieger Bellach 21

Gecher, Dawied - szkutnik 21

Geering, Catharina - ż. $\rightarrow$ Georg Pannenberg 24

Gering, Johan - mieszczanin 26

Gliller, Gottfried - ur. 11 stycznia 1709 r., syn kupca przybyłego z Wrocławia do Torunia; uczeń toruńskiego gimnazjum akademickiego, studiował w Marburgu, rezydent Torunia na dworze królewskim, działacz ewangelicki; w 1760 r. scholarcha, w 1762 - pan wetowy, 1766 - burmistrz, wielokrotny burgrabia i prezydent rady miasta (ostatnia kadencja 1790-1791); zręczny polityk, ale „człowiek ponury i zamknięty w sobie [...] [wywoływał] konflikty z otoczeniem"; jako burgrabia obciążał Żydów nadzwyczajnymi podatkami, co wywoływało liczne skargi; zmarł 17 grudnia 1793 r. [TSB, t. 3, s. 71-72] 47

von Glembocka, ? - wdowa z Torunia 36

von der Goltz, ród 51

von der Goltz, Francisci [Franz] - ur. 21 października 1711 r. w Siemczynie koło Czaplinka, jeden z sześciu synów Henninga Bernharda von der Goltz seniora (właściciela Siemczyna, Rzepowa, Piaseczna, Lasek, Toporzyka, Brostowa, Miasteczka) i Elisabeth Cathariny von Heydebreck; uczeń gimnazjum jezuickiego w Wałczu; od 1728 r. w armii pruskiej w regimencie piechoty von Stille'a, następnie w regimencie von Kleista w Berlinie; wystąpił z armii w 1739 r. w stopniu kapitana i zajął się dobrami rodzinnymi; w 1755 r. został podkomorzym królewskim polskim i saksońskim; w 1756 r. pojął za żonę Marię Elisabeth van Moir primo voto von Schwarzwald; bezdzietny; zmarł 31 grudnia 1769 r. [Westpreussen, Bd. 2, s. 777; Goltz, s. 173, 176] 34

\section{Gotlandia [Gottland] 21}

Göde, Matthias - burmistrz Jastrowia w latach 1743-1749 (być może i następna kadencja), w latach 1756-1764 zajmował stanowisko sędziego miejskiego [Eobżenica, s. 135; Chronik, s. 74, 77] 7, 8

Gręczkiewicz, Antonius Jacobus - pisarz 24, 25

Gritzmesser, Martinus - burmistrz 20

Grodecka, Marianna 75

GroßPohlen $\rightarrow$ Wielkopolska

Grudziadz [Graudenz] 18, 42

Grünenthal, ? - justycjariusz (Justizamter); przed 1776 r. prawdopodobnie w sądzie patrymonialnym $\mathrm{w}$ dobrach radolińskich, a od $1776 \mathrm{w}$ sądzie dominialnym w Pile [Westpreussen, Bd. 1, s. 161; Pita, s. 55] 40, 66

Grützmacher, Johann - burmistrz 18 
Guberlk[...] [?], ? - urzędnik sądowy 34, 36-41, 67, 68

Gubin [Guben] $7 \mathbf{1}$

Guldmann [Guthmann], David 38, 40, 66

Gus(in), Christina - ż. $\rightarrow$ Christian Marcus 52

\section{H}

Haack, Sophia - ż. $\rightarrow$ Gabriel Dumck 4

Habisch, Antoni - ksiądz, w latach 1726-1763 proboszcz w Tucznie; swoim postępowaniem doprowadzał do konfliktów z jezuitami z Wałcza [Bąk, s. 246, 336-337] 75

Hackebeck, ? - radca sądowy 71, 72

Hahn, Anna Catharina - ż. $\rightarrow$ Johann George Lucas 53

Hahn, Anna Maria - c. Mathausa, ż. $\rightarrow$ Johann Willenius 18

Hahn, Elisabeth - ż. $\rightarrow$ Johann George Lucas 58

Hahn, Mathaus - pastor 18

Hein, Regina - ż. $\rightarrow$ Martinus Willenius 18

Hirsch, Abraham 39, 41

Hirsch, David 66

Hirsch, Fabich 32, 37

Hoffstädt $\rightarrow$ Rudki

Holliz [Seidener], ? - aptekarka, ż. [?] Karla Friedricha Seidener [w liście Seidener geboren Holliz] kupca pilskiego. K. F. Seidener - co najmniej drugi mąż wdowy [być może nosiła panieńskie nazwisko „Holliz”?] po Friedrichu Auguście Urban - pierwszym aptekarzu w Pile (zmarł w 1789 r.); budynek apteki Urbana przeszedł w posiadanie małżonków Seidener, którzy dalej prowadzili tam aptekę [Boese, s. 86] 71, 72

Horrc[e], ? - urzędnik magistratu 60

Höllendeund[en], Christoph - szewc 21

Hrabowski, Samuel - vice Kubtes 20

\section{I}

Inowroctaw (-ski) 38, 39, 41, 66

Isert, Johann - mieszczanin 75

\section{J}

Jacob, Abraham 11, 13

Jandick, Catharina - c. Petera, ż. $\rightarrow$ Johann Fenger (st.) 19

Jandick, Peter - sędzia 19 
Jaster, Johann - kowal, rolnik 7

Jaster, Simon (st.) - s. Johanna, kowal, rolnik 7

Jaster, Simon - s. Simona, kupiec jedwabiu z Sypniewa koło Jastrowia, handlował też przyprawami korzennymi, katolik; otrzymał prawo miejskie Torunia 15 kwietnia 1746 r., rajca toruński; zmarł 7 sierpnia 1772 r. [APT, II, I-55, s. 128, poz. 583; HT, s. $35,238,279] 7$

Jastrowie [Jastrow] 7-15

Jeorgi, Johan - m., kupiec, asesor sądowy $\mathbf{5 0}$

Jeschke, Catharina - c. Samuela 26

Jeschke, Jacobus - s. Samuela 26

Jeschke, Samuel - m., rzeźnik 26

\section{$\mathbf{K}$}

\section{kaliskie, województwo $\mathbf{1 7}$}

Kaltersbach, ? - kupiec toruński $\mathbf{6 3}$

Kamień Krajeński [Camen] 17

kamieński, powiat [Camminschen Kreyß] 42, 45

Karkoschke, Martin - starszy i pomocnik rektora gminy ewangelickiej w Łobżenicy [Eobżenica, s. 138; Wirsitz, s. 138-139] 27

Karsibór [Kesburg] $\mathbf{5 2}$

Keler, Paulus - pisarz 8

Kersten, Christian (st.) - s. Jürgena, m., cieśla $\mathbf{5 0}$

Kersten, Christian - s. Christiana, krawiec z Mirosławca, otrzymał prawo miejskie Torunia 22 września 1728 r.; żonaty z Marią z domu Hoffmann, ojciec Johanna Christiana wyuczonego na krawca [APT, II, I-54, s. 113, poz. 548; APT, II, I-55, s. 73, poz. 383] 50, 51

Kersten, Jürgen - kuśnierz $\mathbf{5 0}$

Kirstenius, GJ [?] - burmistrz, sędzia 4

Klawon(en), Sophia - ż. $\rightarrow$ George Stim 7

Klein, David - płóciennik 56, 57

Ktębowiec [Clausdorf] 67

Kohlheis, Catharina Elisabeth [Pillipin] 71, 72

Kohlheis, Jacob Friedrich - brat Cathariny $7 \mathbf{1}$

Kotobrzeg [Colberg] $\mathbf{4}$

Korn, Nikolas - garbarz nowotoruński 66

Koronowo 63 
Kortmann, Johann Gottlob [Cortmann] - m., kupiec, st. gminy ewang. 18, 19, 22, 23

Könilzer, Johann George - st. gminy ewang. 22

Könne, Walentin - m., krawiec 50

Körner, Daniel - burmistrz Jastrowia, w 1726 r. pisarz sądowy i miejski; zmarł przed 1752 r. [Chronik, s. 91] 8

Körner, Johann (st.) - s. Daniela, sekretarz król., burmistrz Jastrowia w 1725 r.; zmarł przed 1752 r. [TSB, t. 2, s. 141; Chronik, s. 74] 8

Körner, Johann Christian 15

Körner, Johann Friedrich - s. Johanna, ur. 5 marca 1728 r. w Jastrowiu w rodzinie będącej elitą miasta; wykształcony na kupca, przybył do Torunia w celu kontynuacji nauki zawodu; prawo miejskie Torunia otrzymał 25 czerwca 1753 r.; członek Cechu Szyprów, Bractwa Strzeleckiego, Korporacji Kupców, ławnik sądu nowomiejskiego, od 1772 r. w radzie miejskiej - piastował stanowiska sędziego nowomiejskiego, wetowego, w urzędzie wałowym, mostowym, kwaternym, szkolnym dla Nowego Miasta i inne; właściciel winiarni i handlarz winami; dwukrotnie żonaty - w drugim małżeństwie bezdzietny, zmarł 11 kwietnia 1795 r. [APT, II, I-55, s. 154, poz. 686; TSB, t. 2, s. 141-142] 8

Krajenka [Krojanke] 16

Krause [?], ? - urzędnik sądowy 44, 46

Krause, ? - cieśla, stolarz 60

Kromeu [?], ? - urzędnik sądowy 44

Kruszyński, Antoni - ur. 19 lutego 1706 r., starszy syn z drugiego małżeństwa kasztelana gdańskiego Waleriana Kruszyńskiego z Teresą z Konopackich; nauki pobierał w Toruniu; wobec postępującej, po śmierci ojca, dewastacji rodzinnego majątku w Nawrze wystąpił wraz z przyrodnim bratem Piotrem przeciw matce; od końca lat 20. zaczął karierę polityczną - piastował urzędy marszałka sejmiku malborskiego, posła na sejm, komisarza w Trybunale Skarbowym w Radomiu; zwolennik elekcji Stanisława Leszczyńskiego, członek frakcji Potockich, później stronnik Stanisława Augusta Poniatowskiego; dwukrotnie żonaty z siostrami - starościankami niechorowskimi z Kochanowskich - Eleonorą i po jej śmierci z Ludwiką; poważany właściciel ziemski, przyjazne stosunki z ewangelickim patrycjatem Torunia; zmarł 29 maja 1774 r. [Nawra, s. 53-75] 74

Kryger, Johannes - burmistrz 75

Kryger, Laurentz 75

Kumm, Michael - piekarz 4

Kurceski, Wawrzyniec [Kurcius] - garncarz 61

Kurcius, Wawrzyniec $\rightarrow$ Kurceski, Wawrzyniec

Kwidzyn [Marienwerder] - papiernia 14, 64 


\section{2}

Krystian Chyrkowski

$\mathbf{L}$

Lachmann, Melchior - pastor 18

Lembcke, Carl Dethaus - rajca 7

Lermont, E. - urzędnik sądowy 69

Leske, Christianus - pisarz sądowy 75

Lettau, Franz Michael - tkacz 55-57

Levin, Caspar [Casper] - kupiec 47, 48

Lędyczek [Landeck] 8

Lindebein, Michael - burmistrz 20, 24-26

Lubno [de Lubno/Lubenau], Martin - mieszczanin, członek zacniejszego rodu Łobżenicy; burmistrz [?], pomocnik rektora gminy ewangelickiej; wymieniony w spisie nazwisk mieszkańców z lat 1750-1759 [Eobżenica, s. 136, 138; Wirsitz, s. 138] 21

Lucas, Johann Christian - s. J. George, stolarz 53

Lucas, Johann George - m., stolarz 53

Lucas, Johann Heinrich - s. J. George, stolarz 53, 54, 58

Lücke, ? - mieszczanin 75

Lüschner, Simon Gottlieb - farbiarz 10-14

Lütcke, Peter - rolnik 7

$\mathbf{L}$

Eadzin [Rehberg] 52

Eobżenica [Lobsens, Lobsentz, Lobseniae] 17-48, 66

\section{M}

Macht, ? - komisarz starościński 74

Mannthej, Martin - m., piekarz z Łobżenicy, wymieniony w Hebeliste z lat 1750-1760 [Eobżenica, s. 129, 135; Wirsitz, s. 138] 24

Marcus, Christian - dzierżawca 52

Marcus, Conrad - s. Johanna, kupiec korzenny z Mirosławca, otrzymał prawo miejskie Torunia 30 sierpnia 1737 r.; ożenił się z [NN] z domu Cashius, ojciec Samuela Conrada, wyuczonego na kupca korzennego [APT, II, I-54, s. 130, poz. 604; APT, II, I-55, s. 107, poz. 496] $\mathbf{5 2}$

Marcus, Johan - s. Christiana, dzierżawca 52

Marcus, Johem - kupiec 59

Marienwerde[r] $\rightarrow$ Kwidzyn

Mattey, Johan - m., asesor sądowy $\mathbf{5 0}$ 
Meissner, [C] G - papiernik 60

Meissner, Chrystian Karol Bogumił - papiernik 60

Meller, Jan Fryderyk - papiernik 70, 72

Milcken [Miecken?], Agata 31

Mirostawiec [Märkisch Friedland, Neu Friedland, Fredland, Fried(t)land] 49-60

Mirucki, Stefan - mieszczanin, wymieniony na liście mieszkańców Łobżenicy z 1768 r. [Eobżenica, s. 125] 26

Mittelstät, Andreas - pastor 1

Mittelstät, Dorothea Catharina - c. Andreasa, ż. $\rightarrow$ Friedrich Olböter 1

Mlüdick [?], ? - burmistrz 6

Molbert, Szymon - pisarz cechu garncarskiego 17

Mrocza 61

\section{$\mathbf{N}$}

Nadarzyce [Rederitz] 7

nadnotecki, obwód [Netz Districkt] 42, 71, 72

nakielski, powiat [Nakelschen Kreis] $\mathbf{4 5}$

nakielskie, starostwo $\mathbf{2 1}$

Nakto nad Notecia [Nakel] 42, 62-64

Neu Berlin $\rightarrow$ Barlinek

Neu Friedland $\rightarrow$ Mirostawiec

Nowa Marchia 8

\section{O}

Ocupowic, Marcin - garncarz 61

Olböter, Friedrich - s. Johanna (st.), st. c. kuśnierzy 1

Olböter [Olbötter], Jacob - mieszczanin i st. c. rzeźników z Czaplinka; prawdopodobnie prezes gminy ewangelickiej, brat Pawła - drugiego (po $\rightarrow$ Schirachu) pastora ewangelickiego w Czaplinku [Bąk, s. 435] 1

Olböter, Johann (st.) - st. c. 1

Olböter, Johann - s. Friedricha, kuśnierz 1

von der Osten - Sacken, Christian - major z Kłębowca koło Wałcza, zięć wdowy po Georgu Wilhelmie von der Goltz; na przełomie 1772 i 1773 r. wytyczał przebieg granicy polsko-pruskiej na południe od Torunia do Inowrocławia, Pakości, Kruszwicy, Strzelna (tzw. Sackenschen Grenzzug); w latach 1773-1775 landrat powiatu wałeckiego [Westpreussen, Bd. 1, s. 46-48, 111; Deutsch-Krone, s. 153] 67 


\section{Krystian Chyrkowski}

$\mathbf{P}$

\section{Patcz [Palsch] 43}

Pannenberg, David - s. Georga, piekarz z Łobżenicy, otrzymał prawo miejskie Torunia 23 kwietnia 1751 r.; wymieniony w spisie nazwisk z lat 1750-1752; ożeniony z Anną Marią z domu Henning, ojciec Johanna Beniamina [APT, II, I-54, s. 175, poz. 663; APT, II, I-55, s. 143, poz. 643; Wirsitz, s. 138] 24, 25

Pannenberg, Georg - m., piekarz 24

Peck, Martin - cieśla 60

Pend [?], Friedrich - st. c. tkaczy 56, 57

Pietius, Johann Tobias - deputowany i starszy gminy ewangelickiej w Łobżenicy; wymieniony w spisie mieszkańców z lat 1750-1772 [Wirsitz, s. 138] 23, 27

Pilasky, Peter Gottlob - pastor pochodzący z Bukowca koło Obornik; w latach 1765-1768 pastor w Łobżenicy, wcześniej w Kostrzynie, uciekł przed konfederatami barskimi do Bukowca; zmarł w sierpniu 1769 r. w wyniku upadku na posadzkę świątyni; wymieniony w spisie mieszkańców Łobżenicy z roku 1766 [Eobżenica, s. 138; Wirsitz, s. 64, 139] 27

Pillipin $\rightarrow$ Kohlheis, Catharina Elisabeth

Pita [Piela, Schneidemühl] 65-72

Pirschel, ? - pisarz sądowy 67-69

Pluwes [?], ? - burmistrz 16

Polkiewicz, Niclos - piekarz 73

Pomorze [Pommern] $\mathbf{4}$

Pomorze Szwedzkie [Shwedshpommern] 21

Potulicki, Aleksander Hilary - starosta borzechowski, herbu Grzymała, General-major, katolik; mieszkał w Gdańsku, właściciel m.in. Sępólna i Więcborka; zwolennik umieszczenia sądu landwójtowskiego w Więcborku; zmarł w 1780 r. [Westpreussen, Bd. 1, s. 124, Bd. 2, s. 761; SGKP, s. 875; von Żernicki, s. 47] 74

poznańskie, województwo $\mathbf{8}$

Preussischen Friedland $\rightarrow$ Debrzno

Prusy Zachodnie [Westpreussen] 56, 57

Przedbramski, Marii - cechmistrz garncarski 17

Ptaszek, Marcin - st. c. garncarzy/zdunów 65

Pyrzyce [Pyritz] $\mathbf{4}$ 


\section{$\mathbf{R}$}

Radecke, V. [?] - urzędnik magistratu 55

Radkiewicz, Catharina [z domu NN] - ż. $\rightarrow$ Jacob Radkiewicz (st.) 75

Radkiewicz, Jacob (st.) 75

Radkiewicz, Jacob - s. Jacoba, krawiec z Tuczna, otrzymał prawo miejskie Torunia 30 sierpnia 1747 r. [APT, II, I-55, s. 133, poz. 597] 75

Radolińscy - -skich dobra/patrymonium 40, 44

von Radolinski, Joseph - syn Józefa Stefana i Teresy z Wybierowa Świniarskiej; w 1754 r. przejął dobra rodzinne, w tym Łobżenicę, w 1772 r. przeniósł się do Winnej Góry koło Poznania; w latach 1773-1778 chorąży wschowski, 1778-1781 podkomorzy wschowski, konfederata barski; w 1774 r. zabiegał o pozostawienie sądu landwójtowskiego w Łobżenicy; żonaty z Katarzyną Raczyńską, mieli sześcioro dzieci; zmarł w $1781 \mathrm{r}$., pochowany $\mathrm{w}$ rodzinnym grobowcu w Jarocinie [Westpreussen, Bd. 1, s. 148; Eobżenica, s. 53-54; Wirsitz, s. 170] 29

Radzicz [Radsitz] 18

Radziejowski, Michał - kard., abp gnieźnieński 17

Rahm, Fridrich Drenck - tkacz 56, 57

Rahz, Johann - m., sukiennik 1

Rederitz $\rightarrow$ Nadarzyce

Rehberg $\rightarrow$ Eadzin

Reinhardt, Anna Catharina - c. Friedricha, ż. $\rightarrow$ Johann Christoph Richter 4

Reinhardt, Friedrich - m., kowal miedzi 4

Reünspis, Peter - rolnik 7

Richter, Johann Christoph - st. c. kowali miedzi 4

Richter, Maria Elisabeth - c. Johanna, ż. $\rightarrow$ Samuel Zimmermann 4

Rogg, ? - wdowa spod Łobżenicy 46

Rohenau, David - m., piekarz, rajca 24

Röhl, Samuel - mieszczanin 6

Różewicz [Rozewicz], Georg - garncarz z Łobżenicy, występuje w spisie obywateli Torunia za rok 1696 - być może wtedy otrzymał prawo miejskie [Semrau, s. 56] 17

Rudki [Hoffstaedt 59

Rudulff, Conrad 49

Ruttich [Ruttig], Christian Andreas - kupiec toruński 66

Ryptow [Ristow], Christoph - burmistrz Jastrowia między rokiem 1714 a 1740 [Chro$n i k$, s. 74] 8 


\section{Krystian Chyrkowski}

\section{S}

Salomon, Johann Ernst - przed 1772 r. szlachecki pisarz sądowy, od 1772 r. sekretarz w Oberhof- und Landesgericht w Kwidzynie; doraźnie skierowany jako komisarz do przyjmowania skarg w miasteczkach obwodu nadnoteckiego; od marca 1773 r. dyrektor sądu landwójtowskiego w Łobżenicy, a od połowy 1775 r. w Pile; w 1782 r. został Justizdirektor powiatowej komisji sądowej w Pile; w lutym 1773 r., jako reprezentant uboższych miast obwodu nadnoteckiego, złożył hołd królowi pruskiemu przed rejencją w Kwidzynie [Westpreussen, Bd. 1, s. 148, 152, 163, 190, 200; Bd. 2, s. 65 , 777-778; Eobżenica, s. 124; Wirsitz, s. 54-55; Boese, s. 61-62] 32-41, 67-69

Salvador, Felix Christian - komisarz starościński 74

Sarepski, Wawrzyniec [Laurentz] - garncarz 61

Schaminik [?], ? - urzędnik sądowy 67, 68

Schendel, Samuel - kupiec, st. gminy ewang. 18, 19, 22

Schiemann, Heinrich - rolnik 42-45

Schirach, Ludwik Baltazar - pierwszy pastor w Czaplinku w latach 1719-1742; popadał w zatargi ze swoim następcą - bratem burmistrza $\rightarrow$ Peterem Olböter $[B a ̨ k$, s. 435, 440] 4

Schlen $\rightarrow$ ? $\mathbf{1 8}$

Schloppa $\rightarrow$ Cztopa

Schmidt, ? - w maju 1782 r. asesor i aktuariusz powiatowej komisji sądowej w Pile [Westpreussen, Bd. 1, s. 200; Wirsitz, s. 55; Boese, s. 64] 69

Schmiedte, Friedrich - krawiec 51

Schneidemühl $\rightarrow$ Pita

Schranck, Maria - ż. $\rightarrow$ Peter Wacholtz 8

Schultz, Michael - burmistrz Łobżenicy w 1754 r., być może w dalszych latach i po 1770 - przynajmniej do 1772 r.; ewangelik [Eobżenica, s. 127, Wirsitz, s. 137] 26

Schultz, P. [?] - st. c. młynarzy 16

Schultz, Peter - mieszczanin łobżenicki i pomocnik rektora gminy ewangelickiej w Łobżenicy [Eobżenica, s. 135, 138] 26

Schulz, Anna - ̇̇. $\rightarrow$ Johann Olböter (st.) 1

Schulzen, Jacob - m., szlachcic 7

Sebastianus - pisarz sądowy 65

Sechs [?], ? - urzędnik sądowy 11, 12, 14, 15

Seidener $\rightarrow$ Holliz

Sępólno Krajeńskie [Sampelborg] 35, 73, 74

Shenud, Dorothea - ż. $\rightarrow$ Jacob Bellach 21

Shwedshpommern $\rightarrow$ Pomorze Szwedzkie 
Sido(in), Maria - ż. $\rightarrow$ Georg Tetzlaff 52

Siekierka, Michael - garncarz 17

Sisty [?], ? - urzędnik sądowy 10-15

Sokołowski, Maciey - pisarz 19

Spiecker, Johann - mieszczanin, st. c. 7

Stare Drawsko [Draheim] $\mathbf{4}$

Staten [?], ? - urzędnik sądowy 46

Steinmetz, ? - rębacz rzeźnicki 70

Stephanus 62

Stim, George - sołtys 7

Stim, Sophia - c. Georga, ż. $\rightarrow$ Simon Jaster (st.) 7

Sto[.]cik, Wo[j]cie[c]h - cechmistrz garcarski 61

S[.] octt [?], ? - urzędnik sądowy 63

Sypniewo $[$ Zipno] 7

\section{$\mathbf{T}$}

Tempelburg $\rightarrow$ Czaplinek

Teschendorfe $\rightarrow$ Cieszyno

Tetzlaff, Elisabeth - c. Georga, ż. $\rightarrow$ Johann Marcus 52

Tetzlaff, Georg - dzierżawca 52

Toruń [Thoren, Thorn] 9-15, 23, 32, 37, 40, 47, 48, 54, 60, 66, 70, 71

Troje, Erttman [Erdman] - burmistrz 52

von Trotter, NR [?] - członek magistratu i sądu miejskiego w Jastrowiu; były oficer armii pruskiej w stopniu kapitana, podskarbi miejski; gorliwy ewangelik, zasłużony przy budowie zboru w Jastrowiu [Chronik, s. 102, 111] 10-15

Tröhlieh, Jacob - asesor rady 8

Tuczno 75

Tytz, Daniel - przed 1756 r. sędzia miejski w Jastrowiu, a od 1756 r. do śmierci w grudniu 1768 r. sprawował funkcję burmistrza [Jastrowie, s. 59, przypis 9; Chronik, s. 74, 77, 80] 8, 9

Tytz, Michael - pisarz cechu kowali w Jastrowiu, w 1758 r. - rajca, w latach 1768-1803 burmistrz (od 1772 r. oficjalnie Polizeibürgermeister); zmarł w 1803 r. [Jastrowie, s. 59, przypis 9, 64; Chronik, s. 63, 74, 80] 8

\section{$\mathbf{U}$}

Uchnahe [?], ? - asesor 56, 57 


\section{Krystian Chyrkowski}

V

Villedary, Jean - papiernik $\mathbf{2 3}$

\section{W}

Wacholtz, Maria - c. Petera, $\dot{z} \rightarrow$ Johann Körner (st.) 8

Wacholtz, Peter 8

św. Wawrzyniec 35

Wassosz-papiernia 11, 14, 60, 65

Wegner, Johann - pisarz sądowy 7

Wegnes [?], ? - urzędnik magistratu 64

Welks, Carl Friederick - rębacz rzeźnicki 70

Wels(en), Elisabeth - ż. $\rightarrow$ Daniel Körner 8

Westpreussen $\rightarrow$ Prusy Zachodnie

Weydowicz, Wawrzyniec - garncarz 17

Węgórczyk, Jan - st. c. garncarzy/zdunów 65

Wiegenstors, H. [?] - urzędnik magistratu 55

Wielkopolska [GroßPohlen] 17, 18, 24, 26, 50-52

Więcbork [Vandsburg] 32-35, 41

Willenius, Johann - s. Martinusa, pastor 18

Willenius, Martinus - pastor 18

Willenius, Theodorus - s. Johanna 18

Wista [Weichsel] $7 \mathbf{1}$

Wittere, Johann Fendler - kupiec toruński 9

Wittzze [?], Schmid - kupiec toruński 9

Wolffschläger, Christian Fridrick - s. Christopha, krawiec z Człopy [na liście nadania prawa miejskiego podano Barlinek], otrzymał prawo miejskie Torunia 3 maja 1771 r. [APT, II, I-55, s. 203, poz. 885] 6

Wolffschläger, Christoph 6

Wreick, ? - ślusarz 4

Wreick, Anna Catherina - ż. $\rightarrow$ Johann Zimmermann (st.) 4

\section{Z}

Zachert, ? - kupiec toruński 63

Zander, Gottlieb - kupiec 64

Zechendorf $\rightarrow$ Czechyń 
Zimdler[...], Gottlob - st. gminy ewang. 27

Zimmermann, Conrad Friedrich - rzeźnik z Czaplinka, otrzymał prawo miejskie Torunia 14 kwietnia 1752 r. [APT, II, I-55, s. 148, poz. 662] 2

Zimmermann, Johann (st.) - leśnik królewski 4

Zimmermann, Johann Christian - s. Samuela, sukiennik z Czaplinka, otrzymał prawo miejskie Torunia 2 września 1753 r. [APT, II, I-55, s. 156, poz. 693] 4

Zimmermann, Samuel - s. Johanna, rzeźnik 4

Zincke [Zineke?], Gottlob - mieszczanin 31

Zipno $\rightarrow$ Sypniewo

Ztocieniec [Falkenburg] 8

Zlotów [Flatow] 11, 13, 14, 26, 60, 65

\section{LITERATURA I MATERIAEY ARCHIWALNE WYKORZYSTANE DO ODWOŁAŃ W INDEKSIE}

APT, II, I-54 - Verzeichnüß der Bürger Söhne so allhier das Bürgerrecht erhalten, Archiwum Państwowe w Toruniu, Katalog II, sygn. I-54.

APT, II, I-55 - Verzeichnüß der Fremden so allhier das Bürgerrecht erhalten, Archiwum Państwowe w Toruniu, Katalog II, sygn. I-55.

Bąk - L. Bąk, Ziemia watecka $w$ dobie reformacji i kontrreformacji w XVI-XVIII wieku, Piła 1999.

Behördenverfassung - M. Bär, Die Behördenverfassung in Westpreußen seit der Ordenszeit, Danzig 1902.

Boese - K. Boese, Geschichte der Stadt Schneidemühl, Würzburg 1965.

Chronik - F. Schultz, Chronik der Stadt Jastrow, Jastrow 1896.

Deutsch-Krone- F. Schultz, Geschichte des Kreises Deutsch-Krone, Deutsch-Krone 1902.

Goltz - Nachrichten über die Familie der Grafen und Freiherrn von der Goltz, zgst. F. von der Goltz, Strasburg 1885.

HT - Historia Torunia. Między barokiem i oświeceniem 1660-1793, t. 3, cz. 2, red. M. Biskup, Toruń 1996.

HUP - S. Kutrzeba, Historia ustroju Polski w zarysie, t. 3: Po rozbiorach, cz. 1, Lwów 1920.

Jastrowie - R. Kozłowski, Jastrowie. Zarys dziejów 1602-2002, Jastrowie 2002.

Łobżenica - A. Mietz, J. Pakulski, Łobżenica. Portret miasta i okolicy, Łobżenica-Toruń 1993. 
Nawra - J. Dygdała, Sz. Wierzchosławski, Nawra Kruszyńskich i Sczanieckich. Studium z dziejów szlachty i ziemiaństwa ziemi chetmińskiej, Torun 1990.

Pita - Z. Boras, Z. Dworecki, Pita. Zarys dziejów, Piła 1993.

Semrau - A. Semrau, Die Bürgerlisten der Stadt Thorn aus dem 17. Jahrhunderte. II Die ausländischen Bürger, Mitteilungen des Coppernicus - Vereins für Wissenschaft und Kunst zu Thorn, H. 28, 1920, s. 40-70.

SGKP - Stownik geograficzny Królestwa Polskiego i innych krajów stowiańskich, t. 8, red.

F. Sulimierski, B. Chlebowski, W. Walewski, Warszawa 1897.

TSB, t. 2 - Toruński stownik biograficzny, t. 2, red. K. Mikulski, Toruń 2000.

TSB, t. 3 - Toruński stownik biograficzny, t. 3, red. K. Mikulski, Toruń 2002.

Westpreussen - M. Bär, Westpreußen unter Friedrich dem Grossen, Bd. 1-2, Leipzig 1909.

Wirsitz - Der Kreis Wirsitz: ein westpreußisches Heimatbuch, bearb. H. Papstein, Bad Zwischenahn 1982.

von Żernicki - E. von Żernicki-Szeliga, Geschichte des Polnischen Adels, Hamburg 1905.

\section{Letters from Wałcz region and Krajna till the end of the XVIII century from the resources of State Archives in Torun}

Summary

This article tries to familiarise the correspondence from Wałcz region and Krajna to Torun magistrate on the basis of letters stored in the holding of State Archives in Toruń.

75 catalogue descriptions of letters from 12 towns located in the north-western territories next to the borders of pre-partition Republic of Poland were presented. One cannot exclude that there are more of them in Torun Archives, but only two sections chosen from so called Catalogue II (Acts of Toruń) and Catalogue III (Craftsman letters) were submitted in the query.

Chronological borders of the correspondence presented are from 1402 to 1799; however, majority of the correspondence come from the XVIII century. The authors are both private persons and institutions (craftsman associations, city councils, evangelical commune council). Among craftsmen and city council letters one can find so called birth certificates (Geburtsbrief), job certificates (Lehrbrief) and recommending letters (Empfehlungsbrief). Court letters concern cases similar to contemporary ones: inheritance issues, suits for vendor cheating, legal proceeding in case of murders and others. Private persons ask the city council of Torun to help them execute debts from Torun inhabitants. Evangelical commune from Łobżenica asks a few times for financial help.

Material gathered in the article constitutes the excellent source for research on chancery's functioning at that time, both when it comes to senders and recipients of letters. One can see some regularity in the forms of some typical documents - just like crafts- 
man letters mentioned above - independently of the town they were issued. After the first partition of Poland (1772), when the territories under discussion were taken over by Prussia, there appeared even printed forms of certificates of craftsmen training. Court correspondence was ad hoc in nature, where only polite forms of address were repeated. Later, letter content was described and the recipient noted down the date of their receipt. Only a few craftsman letters were written on the parchment paper, rest of them were paper. Thanks to that, one can find water marks next to common samples; there are also watermarks hardly ever met in the subject literature. With majority of letters there are seals of senders, among others hanging wax seals, shellac seals, paper-shellac seals and wafer seals.

The correspondence was mainly in German language due to the neighbourhood of Brandenburg and later - Prussia. Latin and Polish languages were used as well. The condition of letters varies a lot - from excellent to poor. Letters of Catalogue III are currently stored separately while the letters of Catalogue II are stored in sewn files. 